\title{
The Institution of the Will
}

The emergence of the will in medieval Europe played a significant role in the social and cultural changes taking place during that era. An examination of the will's history as a social institution reveals it to be a multidimensional phenomenon which was both the cause and effect of many socio-cultural processes. The rediscovery of the ancient concept of the 'testament' was both a manifestation of the deepening Christianization of Europe and a significant driver in that process. However, the testament was only able to be so widely disseminated as a consequence of modernization and individualization processes already taking place in late medieval urban societies. Moreover, depending on the point of view adopted, one can see the will either as a factor undermining the existing family structure and traditional order of property rights, ${ }^{1}$ or as a legal element complementing them, established to fulfil specific functions, including the regulation of one's earthly obligations and the salvation of the soul. ${ }^{2}$ In order to learn more about the meaning of the will, its form and the role it played in various social and cultural processes in late-medieval Krakow (and other large cities in East-Central Europe), it is necessary to trace its history and examine the cultural and legal contexts in which it emerged.

The image of early medieval Germanic and Slavic tribal communities that emerges from an analysis of surviving collections of customary legal rights is one of fairly close-knit collectivities in which a dominant role was played by kinship groups. Patriarchal control and custody over the individual and his

1 Przemysław Dąbkowski agreed with the classical French legal historian Paul Violetta, who proposed the following: "The history of the will is a struggle between the rights of the family and the right to testamentary freedom"; Przemysław Dąbkowski, Prawo prywatne polskie, vol. 2 (Lwów: Drukarnia Uniwersytetu Jagiellońskiego, 1911), 75; "The will based upon the principle of the freedom to dispose of one's property according to one's wishes in the event of death shaped a new legal custom."; Bogdan Bobowski, Kultura materialna mieszczan Świdnicy, 38; cf. Kazimierz Kolańczyk, Studia nad reliktami wspólnej wtasności ziemi w najdawniejszej Polsce. Rozporządzenia wtasnością ziemską do końca XIV wieku (Poznan: Poznańskie Towarzystwo Przyjaciół Nauk, 1950), 71-75; Juliusz Bardach, Historia państwa i prawa Polski do połowy XV wieku (Warszawa: Państwowe Wydawnictwo Naukowe, 1957), 307-308.

2 Urszula Sowina, "Testamenty mieszczan krakowskich o przekazywaniu majątku w późnym średniowieczu i we wczesnej nowożytności," in Sociálni svět středověkého města, ed. Martin Nodl, $173-183$.

(C) JAKUB WYSMUŁEK, 2021 | DOI:10.1163/9789004461444_003

This is an open access chapter distributed under the terms of the CC BY-NC-ND 4.0 license. 
property was exercised by the head of the family and other male relatives. ${ }^{3}$ Ownership (mainly concerning real estate) was ancestral in nature, which meant that a person was only the user and beneficiary of property and not its owner. The goods inherited from one's ancestors were to be passed on to the next generation in as well-preserved a state as possible. ${ }^{4}$ Along with the rise of private ownership of land and increasingly common transfers of real estate, the threat arose that family property would be diminished through transfers to third parties (alienation; primarily to Church institutions). The interests of relatives were safeguarded by medieval collections of laws grounded in the principle of 'the right of kinship' (ius propinquitatis). ${ }^{5}$ The Sachsenspiegel (literally 'Saxon Mirror'), a compilation of customary laws that constituted one of the most significant sources of legal authority in Central and Eastern Europe, devotes a great deal of space to the rules for the inheritance of property. It clearly states that without the consent of his inheritors, no man could transfer their inheritance to a third party. ${ }^{6}$ If a man attempted to do so, his heirs had the right to apply to the court for restitution of the unlawfully transferred property. If there were no direct heirs to the estate, it would pass on to the man's closest relatives, according to the legal principle that "goods circulate like blood," and thus, whoever was "closer by blood" was also "closer to the property."

3 "For the Lombards, [...] it was the kinship group, its common property interests and its control over each of its members, that was of highest value. This was linked with the supremacy of the male head of the family and, particularly, the strict male guardianship (mund) over women and children. The individual was subjected to the group," Karol Modzelewski, Barbarian Europe, trans. Ewa Macura (Frankfurt am Main: Peter Lang, 2015), 76.

4 " [...] aput attavos nostros et patres ex antiquo statutum est, ut si quisquam de genere Polonorum vendiderit quodlibet patrymonium suum, eius heredes postmodum poterunt redimere [...]. Si quicquam possideo quod avus meus et pater mihi in possessionem reliquerunt, hoc est meum verum patrymonium"; Liber Fundationis claustre Sancte Marie Virginis in Henrichow. Księga henrykowska, ed. Roman Grodecki (Poznan: Instytut Zachodni, 1949), 28o; Karol Koranyi, "Podstawy średniowiecznego prawa spadkowego," Pamiętnik HistorycznoPrawn 9 no. 2 (1930), 115.

5 Zygmunt Rymaszewski, Prawo bliższości krewnych w polskim prawie ziemskim do końca XV wieku (Wrocław-Warszawa-Krakow: Zakład Narodowy im. Ossolińskich - Wydawnictwo PAN, 1970), 172-172, 183-187.

6 "Absque heredum consensu et absque iudicio legali nemo suum proprius nec suos homines dare potest"; Jan Łaski, Commune Incliti Poloniae regni privilegium constitutionum et indultuum publicitus decretorum approbatorumque, Krakow 1506, part 2, 209r-209v; "ane erven gelof [...] ne mut nieman sin egen [...] geven”; za: Karol Koranyi, Podstawy średniowiecznego prawa spadkowego, 117 .

7 "Das gut rinnt wie das Blut" kamen die Blutsverwandten des engener Kreises der Hausgemeinschaft in den Genuß des Erbes; beim Fehler solcher bevorzugten Anwärter wurden die restlichen Verwandtschaftsmitglieder entsprechend dem Prinzip “Je näher dem Gut' berücksichtigt"; Paul Baur, Testament und Bürgerschaft, 12. 
The collective nature of property was an expression to some extent of the collective nature of identity, according to which a person was, first and foremost, a member of his or her family, and only then of other, larger community structures. $^{8}$

A different level of importance was attached to movable goods, which originally designated one's personal equipment and belongings, such as weapons, tools, crockery, clothes and jewellery, as well as a person's livestock. Although it was land that determined a person's social status, the moveable goods one possessed were also symbols and determinants of one's wealth. ${ }^{9}$ They had long been treated as private property, inseparable in principle from the person possessing them; according to the ancient adage, 'movables adhere to the bones' of their owner (in Latin mobilia ossibus inhaerent). This subjective nature of movable property was emphasized both by early medieval compilations of laws, according to which the theft of a living - or dead - person's possessions was just as severely punished as causing that person bodily injury, as well as by old pagan funeral customs, according to which the deceased took some of their personal belongings with them to the grave. ${ }^{10}$ With the spread of Christianity, old burial traditions involving ritual cremation were replaced by the practice of burying the dead in the ground. Gifts stopped being placed in graves, and were instead given to the churches where the graves were now located. In this way, the Church's successful Christianisation of followers of the older pagan religion led to the transformation of their 'grave gifts' (Totenteil or Totengabe) into pious bequests meant to aid in the salvation of the deceased donor's soul (so-called Seelgerät)."11

While a distinction between movable and immovable property is commonly found in medieval sources, a number of movables identified in land and municipal collections of rights also became classified over time as hereditary property. This was the case of the personal equipment and belongings of men (in German hergewet, in Latin arma bellica) ${ }^{12}$ and women (in German gerada, in Latin paraphernalia, suppellectilia [...] que admulieres pertineant "accessories

8 " $[. .$.$] Germanic law initially did not provide for the disposal of any real estate, while$ heirs had far-reaching rights. This stemmed from the structure of the Germanic family itself, which was based on family co-ownership of real estate"; Karol Koranyi, Podstawy średniowiecznego prawa spadkowego, 120.

$9 \quad$ Ibid., 40.

$10 \quad$ Ibid., $5^{-8,}, 46$.

11 Gabriele Schulz, Testamente des späten Mittelalters aus dem Mittelrheingebiet, 3. 
that belong to women"13), ${ }^{14}$ which were supposed to be transferred into hands of their male or female relatives, respectively. ${ }^{15}$ According to Magdeburg Law (Magdeburgisches Weichbild), a deceased husband's wife was to pass on to his male descendants his sword, his best saddled horse and best armour, as well as his pulvinar bellicale "military bed," which included a bed, two pillows, two sheets, a tablecloth, two bowls and a towel. ${ }^{16}$ The hereditary property of a wife that was to be received by her daughter, and otherwise by her closest female relative, was much more extensive. Although in Łaski's Statutes these were defined as being only her sheep, dishes and the food in her home, ${ }^{17}$ in the judgments of Magdeburg Law, translated into Polish in $1501{ }^{18}$ these were described with much more precision as: the woman's silver and gold jewellery, cups, chalices, spoons, cupboards (in Latin armarium), wash-basins, cushions, sheets, pillows, tapestries, carpets for covering benches (In Latin bancalis) and beds and hanging on walls, tablecloths, towels, quilts, clothing, headscarves, chests, candlesticks, yarn, beer brewing kettles and books 'that women tend to read,' as well as a pot for melting wax, a mirror, scissors and other items commonly used by women..$^{19}$ In 1567 , Bartłomiej Groicki, a notary at the High Court of Magdeburg Law in Krakow, described the Weichbild as follows:

These things belong to the woman's movables [gerada] according to Magdeburg Law: all the woman's clothing, gowns and cloth cut for the clothing the woman typically wears and has power over; all gold and silver that is woven for the woman's clothing; all rings, buttons and pins, buckled belts, silk cloth, bracelets and necklaces, bed coverings, sheets, bath towels, curtains, lace curtains, beds, head-rests, pillows, table-cloths, bowls, brewery vessels to be leased, a wash-boiler, crates with lids, linen, washed and raw wool; books that women usually read; geese, ducks, sheep that are herded out to pasture. ${ }^{20}$

\footnotetext{
13 See Glossary: Gerada

14 Urszula Sowina, Testamenty mieszczan krakowskich o przekazywaniu majątku, 176-177.

15 In the collection of laws published by John Łaski there appears the phrase "De suppelectili, que ad mulieres pertinebat"; Jan Łaski, Commune Incliti Poloniae regni privilegium constitutionum et indultuum publicitus decretorum approbatorumque, Libri duo, part 1 (Krakow, 1506), 187r.

16 Ibid., $187 \mathrm{r}$.

17 Ibid., $187 \mathrm{r}$.

18 Michał Wiszniewski, Historya literatury polskiej, vol 5 (Krakow: Drukarnia Uniwersytecka, 1843), 151-163.

$19 \quad$ Ibid., 237-238.

20 Bartłomiej Groicki, Tytuty prawa majdeburskiego (Warszawa: Wydawnictwo Prawnicze, 1954), 5 .
} 
The gerada was described in a nearly identical fashion by Paul Szczerbic in $1581 .^{21}$

The first major departure from the traditional principles of property inheritance was the development of the principle of excluding a so-called 'free portion' (Freiteil) from the inherited property. Calls to donate part of one's estate to the Church - that is, as the Church fathers worded it, to "include Christ among the heirs" of the deceased - began to be made in the late fourth century. ${ }^{22}$ St. John Chrysostom determined the size of God's part of the inheritance to be from a half to one-third of the estate, while St. Augustine based the size of the part to be set aside for the Church on the number of sons the deceased possessed. ${ }^{23}$ As the Church's power grew in the early Middle Ages, these appeals met with a more accommodating response. In spite of the established inviolability of family property in Christian Europe, the principle was adopted that, from a free one-third portion of an estate, it was possible to make an act of alms-giving called a donatio mortis causa "gift because of death." ${ }^{24}$ Unlike other types of gift, the donation of the 'free portion' for alms-giving and for funeral preparations was legally valid even if the legal heirs opposed it. ${ }^{25}$ In order to secure these pious bequests against the protests of relatives, from the fifth century onwards councils used the threat of excommunication against those who failed to fulfil the will of the deceased, while the bishops were obliged to oversee the donation of these goods. ${ }^{26}$

Paweł Szczerbic, Ius municipale, to jest prawo miejskie majdeburskie, nowo z tacińskiego iz niemieckiego na polski język z pilnością i wiernie przetożone, ed. Grzegorz Maria Kowalski (Krakow: Księgarnia Akademicka, 2011), 118-119. Michael M. Sheehan, The Will in Medieval England, 11.

23 Karol Koranyi, Podstawy średniowiecznego prawa spadkowego, 194-195; Gabriele Schulz, Testamente des späten Mittelalters aus dem Mittelrheingebiet, 2; Paul Baur, Testament und Bürgerschaft, 12; Brigitte Klosterberg, Zur Ehre Gottes und zum Wohl der Familie, 53-54. Harold Joseph Berman, Law and Revolution. The Formation of the Western Legal Tradition (Cambridge-London: Harvard University Press, 2009), Warszawa 1995, 288.

"Von diesem ursprünglich allein im Hinblick auf das Seelenheil verwendbaren Seelteil ist der Freiteil der Hinterlassenschaft des Erblassers zu unterscheiden, welcher sich aus der christlichen Caritaslehre Augustinscher Provenienz entwickelte und einen exakt quotierten Pflichtteil des Erbes für die Kirche als Vertreterin Christi auf Erden bezeichnet. Einer Zustimmung seitens des wartberechtigten Erben über diesen Teil seines Erbes bedurfte es hierbei nicht"; Paul Baur, Testament und Bürgerschaft, 12.

26 "The Church was not content to urge that these legacies be given; she even interested herself in their accomplishment. Councils of the fifth century excommunicated those who failed to distribute bequests in alms according to the wishes of the dead. The bishop became concerned with the supervision of the delivery of these legacies, and in time the laws of Justinian confirmed certain rights to him in this regard"; Michael M. Sheehan, The Will in Medieval England, 11. 
Yet it was the will, following its rediscovery and reintroduction in medieval Europe at the turn of the eleventh and twelfth centuries, that proved itself to be the most effective instrument for ensuring a steady transfer of goods to an increasingly institutionalised Church. ${ }^{27}$ The rediscovery of the will in the broad social consciousness of both the clergy and laity of that time was directly caused by the initiation of scholarly studies on Roman law led by a group of clerics and subsequently the creation of canon law based on it. Roman law carried with it an existing body of theory on the nature of the testament, its form and the types of goods which could be legally transferred in this way. It also provided the courts with tools to uphold and enforce testamentary dispositions. $^{28}$

The testament, as it had been understood in medieval Europe since the mid-twelfth century, differed significantly in certain aspects from its ancient predecessor. Roman testaments relied primarily on the appointment of the head of the family, the pater familias, as its legal successor, which resulted, on the one hand, in the transfer of all goods to the heir and, on the other hand, in the exclusion of all other potential successors from them. ${ }^{29}$ This freedom of the father of the family in disposing of private property was a generally accepted value, and it is easy to understand the surprise expressed by Tacitus in his description of the habits of Germanic tribes, where he states that they did not have wills, and that their only heirs and successors were their children. ${ }^{30}$ The medieval testament, or 'last will' (ultima voluntas), both terms at that time were synonymous, was a collection of individual legacies for different persons and institutions (therefor often referred to in German literature as Legatentestament), and did not necessarily involve the designation of an heir to the estate or refer to the entirety of the deceased's property. ${ }^{31}$

27 "One of the many important developments that characterize the life of Europe during the last decades of the eleventh and whole of the twelfth centuries was the revival of the study of Roman civil law. In its wake came a considerable organization and adjustment of law, legal theory and practice. [...] The institutions that come to be better known was the testament, a legal act controlling the devolution of a testator's estate more efficiently than anything that the peoples of northern Europe had been able to devise"; Ibid., 119-122.

28 "Roman law provided a theory of the testament and its nature, prescribed its forms and the limits of the property with which it might deal, and furnished a jurisprudence for the courts which controlled and enforced it"; Ibid., 119 .

29 Gabriele Schulz, Testamente des späten Mittelalters aus dem Mittelrheingebiet, 1-2.

30 Publis Cornelius Tacitus, Germania, trans. Tomasz Płóciennik, introduction and comments by Jerzy Kolendo (Poznan: Wydawnictwo Naukowe UAM, 2008), III, 20.

31 "Das deutsch-rechtliche Testament stimmte mit dem römischen Testament überein im Charakter als einseitig gefaßte, letztwillige Verfügung von Todes wegen sowie im Moment der Widerruflichkeit. Im Unterschied aber zum römischen Testament mußte 
The reception of Roman law and its gradual penetration into the codification of customary laws were important in ensuring wills their theoretical legal basis. However, the support of the Church as an institution was also a decisive factor in the adoption and dissemination of these acts. At the turn of the twelfth century, work was carried out with the help of the Codex Justinianus on the codification of the canons of the Church, which led St. Ivan of Chartres to revive the idea of the freedom to dispose of goods by means of a will. ${ }^{32}$ With the Decretum Gratiani (c. 1140), the concept of the testament had established itself in the medieval Christian world. In his Decretum Gratian evoked the Roman concepts of the right to make alms from the testator's property and the freedom to choose the place of burial. Since then, the part of the property transferred to the Church was limited only by the Roman principle of the so-called pars legitima, ${ }^{33}$ intended for the heirs of the deceased. The successors of Gratian went even further, increasing the power of bishops to defend their wills, while at the same time reducing the number of witnesses needed to recognise the legality of the will. ${ }^{34}$ Under the threat of the most severe religious sanctions, Pope Alexander III defended the validity of wills made in the presence of two or three witnesses, proving in this respect the superiority of canon law over Roman law (which required either seven witnesses). In a letter (from 1171-1172) to the Bishop of Ostia, the Pope maintained that it was the law and custom of the Church to allow people to make wills at the end of their lives before the parish priest and two or three witnesses. ${ }^{35}$ In other letters he emphasized the obligation of relatives and heirs to pay the debts of the

das deutsch-rechtliche Vermächtnis nicht notwendigerweise eine Erbeneinsetzung enthalten und sah auch keine Einsetzung in das gesamte Vermögen des Erblassers vor, d. h. es kannte keinen Gesamtrechtsnachfolger. Vielmehr war es ein Legatentestament, d. h. ein Testament, welches auf eine Mehrzahl von Einzelvergabungen festgelegt war. Es stellte »eine mehr oder minder umfassende Aufzählung von Einzelyermächtnissen dar, wobei die Summe dieser Legate keineswegs dem Gesamtvermögen gleichzukommen« brauchte. Ein weiteres Charakteristikum ist es, daß gesetzlich geregelte Erbfolge und unbeschränkte Verfügungsfreiheit nebeneinander bestehen konnten"; Gabriele Schulz, Testamente des späten Mittelalters aus dem Mittelrheingebiet, 3-4; Brigitte Klosterberg, Zur Ehre Gottes und zum Wohl der Familie, 12; Paul Baur, Testament und Bürgerschaft, 13.

32 Michael M. Sheehan, The Will in Medieval England, 121-122.

33 Roman law, in Justinian's codification, provides for the division of property into three or four parts, at least one of which had to be passed on to legal heirs (the so-called pars legitima).

34 Michael M. Sheehan, The Will in Medieval England, 128.

35 Brigitte Klosterberg, Zur Ehre Gottes und zum Wohl der Familie, 53; Gabriele Schulz, Testamente des späten Mittelalters aus dem Mittelrheingebiet, 10-11. 
deceased ${ }^{36}$ - later, bequests concerning the settlement of liabilities towards debtors would become a permanent fixture of wills. The work of the decretalists (a school of canon law interpretation which emphasised papal rulings on matters of church discipline) and its support by church synods and by popes in the twelfth-century led to the creation of the institution of the so-called 'canonical will,'37 whose rules and form differed from those of Roman law. The canonical will also differed from Roman wills in its function - providing a legal basis for pious requests, and thereby facilitating them and ensuring their effective fulfilment for the benefit of the Church. In northern Europe, the testament was for a long time a part of canon law rather than secular law and, therefore, pious bequests constituted the major part of such acts and were the primary motivation for creating them. ${ }^{38}$

\section{$\mathbf{1}$ \\ Wills in Poland in the Twelfth and Thirteenth Centuries}

In the Polish lands the notion of a last will, understood in the sense of the canonical will, is already visible in bequests from the mid-twelfth century onwards. ${ }^{39}$ In the foundation charter of the Cistercian abbey in Łekno, issued by Count (comes) Zbylut in 1153, a donation to the monastery of one of the

$36 \quad$ Michael M. Sheehan, The Will in Medieval England, 129.

37 "Das älteste Zeugnis für das Bestreben der Kirche, das kanonische Testament in Deutschland zu verbreiten, ist ein Beschluß der im Jahre 1266 in Bremen abgehaltenen Synode, die unter der Leitung des päpstlichen Legaten, des Kardinals Guido, stand. Gemäß diesem Beschluß wurde die »libera testandi facultas« der Laien, und zwar die kanonische Testamentsform gegen gewisse dawiderlaufende Statuten unter deutlichem Hinweis auf Lübeck in Schutz genommen"; Gabriele Schulz, Testamente des späten Mittelalters aus dem Mittelrheingebiet, 11.

38 An important factor which contributed to such a strong support of the institution of the will by the Church authorities was the dispute with the secular authorities over the property of deceased clergymen, the so-called ius spolii. The will made it possible for the clergy to pass on their possessions according to their wishes, thus preventing them from being seized by a feudal lord. Casimir II the Just waived the right to iuris spolii in 1180, as the first ruler on the territory of Poland; Cf. Juliusz Bardach, Bogusław Leśnodorski, Michał Pietrzak, Historia ustroju i prawa polskiego (Warszawa: Lexis Nexis, 20oo), 77; Gabriele Schulz, Testamente des späten Mittelalters aus dem Mittelrheingebiet, 8-9.

39 The oldest collection of Polish laws, written in the thirteenth century, provided only for the possibility of statutory inheritance, according to which sons inherited from their father, while daughters only had the right to a dower chosen by their father or brothers. In the absence of sons, the family property was to be transferred to prince, who was obliged to provide the daughters of the deceased with a dowdry on his behalf if they were to marry. This document, although compiled in the thirteenth century, applies to earlier 
villages he inherited was described as a 'testament.' For those who intended to oppose this 'testamentary privilege' (huius testamenti [...] privilegium), the document threatened punishment of 'eternal anathema' (perpetui anathematis), resulting in the 'absorption of the living into hell' (infernus eum vivum [...] absorbeat).$^{40}$ The word 'testament' was used in a similar context in High Duke of Poland Mieszko III the Old's confirmation of the foundation of a Benedictine monastery in Mogilno (c.1143). In this case as well, those who sought to undermine the donation were threatened with excommunication. ${ }^{41}$

Another interesting testamentary bequest is one made in $119 \mathrm{o}$ by the knight Dzierżko, brother of Wit, bishop of Płock. Before embarking on a crusade, he donated his property to the nuns of the Abbey of Norbertine, which he himself had founded in the village of Busko. ${ }^{42}$ However, he made this donation dependent on the life path taken by his widow. If she re-married after his death, she would receive just one village, while if she remained a widow, she would have full possession of two villages and all of the servants and domestic staff, and if she agreed to enter the Norbertine abbey he had founded, she would also receive eight other villages and part of the village of Busko. However, if she chose to join another order, she would receive only her robes. ${ }^{43}$ In this

times; Cf. Najstarszy zwód prawa polskiego, ed and rev. Józef Matuszewski (Łódź: Panstwowe Wydawnictwo Naukowe, 1995), 85-87.

"Quapropter, huius mei devoti studii factive testamentum ne ulla umquam superior seu inferior persona prava machinatione ducere possit in irritum, sed ut integrum et inconvulsum maneat in perpetuum, dominum Iohannem sancte Gneznensis ecclesie archipresulem, dominum Stephanum Poznaniensis ecclesie antistitem, dominum Mesiconem ducem, aliasque perplurimas personas sublimes ac humiles convocavi, ubi ab utroque episcopo coram astante multitudine sub perpetui anathematis obtentu confirmari votis omnium michi congaudentium impetravi: ut si quis in presens sive in posterum huius testamenti prevaricari presumpserit privilegium, superni iudicis sine misericordia sententiam incidat, infernus eum vivum nisi resipuerit absorbeat"; KDW, vol. 1, no. 18 (1153).

"Fecique ego Mesco dux Polonie hoc meum confirmatorium testamentum super his omnibus tam scripto quam sigillo, tum etiam testimonio vero atque idoneo hic superscripto, concedens non solum Radeow per Cuiaviam, sed et omnibus villis per Poloniam sancto Iohanni in Muglin spectantibus magnam ab omni meo iure meorumque successorum in omnibus libertatem; confirmans hoc excommunicationis vinculo superiori, si quis hec post nos attemptaverit infringere quamdiu mundus steterit"; KDW, vol. 1, no. 33 (1143?).

This was a women's order affiliated with the Norbertine monastery in Witowo, founded by his brother, Wit of Chotel, bishop of Płock; Codex diplomaticus Poloniae, vol. 1, no. 6, eds. Leon Rzyszczewski, Antoni Muczkowski, Antoni Zygmunt Helcel, Julian Bartoszewicz (Warszawa: Drukiem Stanisława Strąbskiego, 1847), 15-16.

43 "In nomine patris et filii et Spiritus sancti. Ego Dirsco aduc [sic] vivens, offerens trado deo omnipotenti et beate Marie, fratribus et sororibus sub regula beati Augustini in Buzsk manentibus, quos de Vitov per manum meam adduxi, pro salute anime mee, bona mea 
document, written before the altar of the Blessed Virgin Mary in the church he had founded, Dzierżko stated that if any of his relatives tried to oppose his bequest, "Almighty God and his merciful mother Mary" would punish them. ${ }^{44}$

The number of pious donations of this kind began to increase significantly in the early thirteenth century. While they performed the same function as they had earlier - acting as a donation or bequest of real estate to religious institutions - they now began to be strictly defined as wills or testaments. For example, a testamentaria dispositio containing a bequest of villages and lakes to the above-mentioned Łekno Abbey dates back to 1216. In this document, apart from the donation of hereditary land, the donor, Świętosław (Sventoslaus) also bequeathed his other possessions to his wife and relatives. This act was made before the abbot, prior and other monks from the recipient monastery, who confirmed it with their seal and warned (just as was done in the Komes Zbylut donation mentioned above) "that those who opposed it would face 'anathema."'45

in hunc modum. Si uxor mea alteri viro nubere voluerit, Visloca ei detur; si in vidvitate, in habitu seculari permanserit, Viznicia sibi addetur; et in his duabus tantum permaneat, cum familia sua, servis videlicet et ancillis; cetera locus habeat. Si vero aliquando divina mediante clemencia, in prefato loco, habitum religionis suscipere voluerit, ut mihi sub iuramento quandoque promisit, omnes hereditates meas ei do: scilicet partem meam de Buzesk cum iumentis, Nosovo, Petrovo, Tuchapi, Bezdruovo, Rechovo, Viznica, Corenovo, Premislovo. Si autem in alio claustro habitum suscipere voluerit, de his omnibus supra dictis hereditatibus et de familia, de ceterisque bonis nichil penitus sibi detur, preter vestes quibus legitur"; Ibid.

44 “[... set omnia non frater meus Episcopus Vitus, immo fratres et sorores supradicte religionis perpetuo iure obtineant. Hec autem dicta et scripta sunt in ecclesia beate Marie ante ipsius altare, sub testimonio solius dei et genitricis eius, dominique Johannis primi ibidem prepositi, facta ad eum confessione, et sacri corporis et sanguinis Christi de manu ipsius communione sumpta, dum ad bellum processi. Hec si dominus Episcopus V[itus] frater meus, vel aliqui alii cognatorum meorum immutaverint, deus omnipotens et mater pia virgo Maria vindicet in eis: sub cuius teslimonio sunt hec facta. Amen"; Ibid.

"[...] universis, quam etiam omnibus Luknensis ecclesie monachis tam presentibus quam posteris ego Sventoslaus notum facio, quia sanus mente meam villam Bracholino cum Jacubus integris claustro contuli. Zabicino et Moracino aliquis cognatorum pro pecunia vendat, qua videlicet pecunia creditoribus meis debita mea persolvantur, et quod residuum fuerit, pars pro Terra Domini et pars Romam mittatur. Uxori vero mee partem de Lukna que me attinet, Sedlez, Balosliw habebit, ut pro illis anniversarium mee depositionis singulis annis usque ad finem vite valeat observare. Post obitum ipsius, filii fratrum meorum ipsas villas dividant. Radgost vero nullo impediente libere pro se habebit, et reliquas villas post fluvium qui Uvira vocatur iacentes, pueris Drogomiri fratris mei senioris longe postea [sic] dabit, qui, seu filii ipsorum, cetera inter se dividant. Denique familiam meam, prout usque commisimus, uxor in memoria habeat. Et ne quispiam hoc in posterum mutare possit, scripto commendamus, sub testimonio Hugoldi abbatis, 
Duke Władysław Odonic used the term 'testament' to refer to an act endowing land to the Knights of St. John of Jerusalem (the Knights Hospitaller) in 1237 for the establishment of a monastery in Korytowo. The act contained language similar to that used by the Church fathers since the time of John Chrysostom in the fourth century: "Who would bequeath his earthly possessions to so many heirs and not make Christ an additional heir? From among all the possessions he secures for other people, a portion should be given to Him." ${ }^{\text {"6 }}$

Among other documents that have survived from the latter half of the thirteenth century are testamentary donations of real estate made by representatives of local elites, ${ }^{47}$ the will of Princess Salomea of Krakow, who had been brought to Poland from Prague and who entered a monastery of Poor Clares (of the Order of St Clare), ${ }^{48}$ and numerous other confirmations of testamentary donations. ${ }^{49}$ Another interesting document is that concluding a dispute in 1258 between three relatives of a deceased palatine, Bogusz, and his widow Ludmiła, which was adjudicated by Duke Bolesław v the Chaste. Three knights (milites) - Świętosław, Simon and Chwalibóg - claimed that their relative could not transfer any inheritance to the Church or alienate it by any other means without their knowledge and consent or that of the Duke. ${ }^{50}$ However, after reviewing the case, hearing witnesses' testimonies and consulting his barons (barones), the Duke decided that the last will and testament of the deceased was lawful and should be fulfilled. A strong defence of the will was voiced by the Bishop of Krakow Paul of Przemyków in the dispute between St. Kinga, Duke Bolesław the Chaste's widow, and his heir Leszek II the Black. Kinga,

Henrici prioris, Iacobi subprioris, Arperni, Leopoldi et Norberti sigillo nostro confirmamus, anathematisando eos qui huic deliberationi contradixerint. Anno Domini millesimo ducentesimo decimo sexto"; KDW, vol. 1, no. 88.

46 "Testamentum suum non bene disponit, qui terrenis tantum heredibus testatur et non facit Christum sue substantie conheredem: universa bona qui prestat hominibus, partem debet recipere prestitorum"; KDW, vol. 1, no. 202.

47 E.g., the will of Comes Lanchomir of 1271: "Anno Domini milessimo ducentesimo septuagesimo primo, decimo octavo Kalendas Februarii, ego comes Lanchomirus bona deliberatione habita, cupiens placere domino Jesu Christo, in mea ultima voluntate et condens testamentum delego et assigno beato Petro apostolorum principi ad ecclesiam Cruswiciensem villam meam que Procino nuncupatur"; KDW, vol. 1, no. 442.

48 KDM, vol. 1, no. 76 (1268).

49 There are at least three surviving documents of this kind issued by Prince Bolesław the Pious, and two issued by Prince Przemysł II; KDW, vol. 1, no. 354, 408, 446, 478, 54 O.

$50 \quad$ "[...] supradicti milites S. et C. et S. proposuerunt, quod cum ipsi essent veri consanguinei memorati palatini, ideo palatinus sine eorum connivencia et consensu ac domini terre, nullas hereditates posset alicui ecclesie in testamento legare, nec sub aliquo alio titulo alienare"; KDM, vol. 2, no. 454 (1258). 
who, like Salomea, entered the Poor Clares' monastery in Skała, bequeathed to the order the income from customs duties she had inherited as well as thirty villages with a significant total value of 20,0oo grivna of pure silver. ${ }^{51}$ The bishop gave Duke Leszek the choice of recognizing the will or purchasing the bequeathed property for the above-mentioned sum. If the new Duke did not accept his decision, the bishop warned that he would defend the princess' bequest with all his strength. ${ }^{52}$

\section{$2 \quad$ Church Guardianship over Wills}

The above examples of wills from the twelfth and thirteenth centuries share several characteristic features. First, they were acts made by members of the elites of several of the provinces and principalities of the Polish Kingdom in the times of its feudal fragmentation. This included princes or their widows, palatines (voivodes) and local magnates. Of course, even before the mid-twelfth century, a similar circle of elites was already interested in establishing new churches and abbeys. Since the thirteenth century, however, the majority of these diverse pious bequests were referred to as wills, due in part to the special protection these acts received from Church authorities. There seems to be a clear link between 'testaments' and the evolution of canon law, not only because of the pious purpose of these bequests, but also because they contained the formulaic expression 'to include Christ among their heirs' and threatened those who challenged them with the punishment of excommunication.

It also seems probable that there was a connection between the emergence of the canonical will in Poland and the arrival of new religious communities. This is indicated by the fact that the first mentions of wills are associated with the coming of the Cistercians to Łekno ${ }^{53}$ and the Norbertine nuns to Busko. Later, thirteenth-century foundations which were also referred to as a 'testament and last will' (testamentum et ultima voluntas), ${ }^{54}$ were connected with

\footnotetext{
$5^{1} \quad$ See Glosary: Grivna

$5^{2}$ "Si uero sepedictus dux L. nullam predictarum ordinacionum uellet admittere, extunc nos una cum amicis nostris iusticiam ipsius domine contra quemlibet hominem uel personam constanter promittimus deffensare"; KDM, vol. 2, no. 491 (1281).

53 The influence of the Cistercians on the freedom to transfer of property was also discussed by Kazimierz Kolańczyk; idem, Studia nad reliktami, 33.

54 KDM, vol. 2, no. 454 (1258).
} 
the arrival of the Franciscan ${ }^{55}$ and Dominican ${ }^{56}$ religious orders to Polish lands. Perhaps it was the members of these new mendicant orders who were responsible for introducing and popularising the institution of the will in these lands, which would have been in their own interests. ${ }^{57} \mathrm{~A}$ strong link between wills and the Franciscan and Dominican orders established in the early thirteenth century is also indicated by a letter by Pope Innocent IV from 1245, addressed to members of these orders in Poland. He called on the authorities of both mendicant orders to ensure that donations made by testators as pious deeds (in pios usus), the purpose and recipient of which were usually left up to the will's executors, would be dedicated to the defence of the threatened Latin Empire. ${ }^{58}$

An essential factor in the adoption of this new form of donation was the support it received from state and ecclesiastical authorities, which safeguarded a testator's will from the challenges of heirs and relatives barred from

55 These include the testamentary bequests of blessed Salomea of Krakow and St. Kinga.

56 E.g. the testamentary bequest made by Segneus heres de Cossek et de Plassow of 6o grivna for the Dominicans; KDM, vol. 2, no. 595 (1329).

On the role of mendicant orders see Wspólnoty zakonne w średniowiecznej Polsce [Religious Communities in Medieval Poland] (Lublin: Wydawnictwo KUL, 2010), 120-134.

58 This letter was issued at a time when the political situation was getting increasingly complicated after the conquest of the Holy Land by Muslims in 1244 and shortly after the end of the first Council of Lyon. "Innocentius episcopus servus servorum Dei, dilectis filiis [...] priori Predicatorum et [...] ministro Minorum fratrum in Polonia, salutem et apostolicam benedictionem. Etsi ex suscepte servitutis officio cunctorum nobis cura imineat generalis, de succursu tamen imperii Constantinopolitani tanto propensius cogitare nos convenit, quanto ex hoc augmentum ortodoxe fidei, magnum Terre sancte subsidium, salus totius Christiani populi procurantur. Ad ipsius itaque imperii liberationem totis desideriis aspirantes, discretioni vestre per apostolica scripta in virtute obedientie districte precipiendo mandamus, quatinus ea, que relinquntur distribuenda in pios usus secundum arbitrium executorum testamentorum decedentium in Polonia et aliis locis ad que tuus fili prior prioratus et tua fili minister amministratio extenduntur, nisi prefata relicta ab ipsis testatoribus certis locis aut personis deputata fuerint vel de iure aliis debuerint, aut per predictos executores in usus huiusmodi sint conversa: fideliter per vos vel per aliquos de fratribus vestrorum Ordinum providos et discretos, quos ad hoc ydoneos esse noveritis, auctoritate nostra colligere, et apud aliquem tutum locum pro eiusdem imperii subsidio deponere cum omni diligentia procuretis, quantitatem ipsorum nobis postmodum rescripturi, contradictores per censuram ecclesiasticam appellatione postposita compescendo. Non obstantibus constitutione de duabus dietis, edita in Concilio generali, et indulgentia qua fratribus vestrorum Ordinum dicitur esse concessum, ne de causis que per litteras apostolicas commituntur eisdem, cognoscere teneantur, nisi de indulgentia huiusmodi expressam faciant mentionem. Quod si non ambo hys exequendis potueritis interesse, alter vestrum ea nichilominus exequatur. Datum Lugduni II Kalendas Octobris, pontificatus nostri anno tertio"; KDW, vol. 1, no. 247. 
inheritance. Good examples of such protection include the above-mentioned judgment of the Duke of Krakow and Sandomierz Bolesław the Chaste, and Bishop Paul's opposition to Leszek Czarny's refusal to respect the will of his predecessor. An excellent example of the church's guardianship over such acts are the statutes issued in 1279 in Buda by Bishop Philip of Fermo, the papal legate for Hungary, Poland and Dalmatia. He devoted significant space to the principles to be followed in the drafting of wills, both by the clergy and laity, referring to the principle in canon law that testaments and acts of last will are under the jurisdiction of the office of the bishop. As a result, he enjoined both orders to submit their last wills to the priest of the parish to which they belonged, in the presence of trusted witnesses. ${ }^{59}$ In the early fourteenth century, bishops in Krakow also began issuing decrees in their statutes concerning the drafting and fulfilment of wills. ${ }^{60}$ The statutes issued by Bishop Nanker in 1320 contain an article referring to bequests of last will, but only those made by clergy. In it the bishop instructed deans that, upon learning that a parish priest or presbyter under their care was seriously ill, they were to send two or three priests to him who would witness and write down the will, and thereby secure the property of the dying person. Furthermore, a part of these goods were to be set aside for a proper funeral, presided over by the local chaplains and vicar, and a part to execute the will, i.e. pay off the debts and fulfil the pious bequests of the testator, while the remaining property would be set aside for the benefice of his successor. If a member of the laity attempted to forcibly seize something from the estate, the dean was to excommunicate them publicly in the name of Bishop Nanker, until he or she decided to return the property. Those who opposed the clergy were also threatened with a fine of one grivna of silver. ${ }^{61}$ This decree was issued in response to a frequent cause

59 "De testamentis. Quum ad episcoporum spectat officium ut extreme legitime voluntates fidelium effectum mancipentur, precipimus et mandamus, ut tam clerici quam laici, quum sua voluerint condere testamenta vel ultimas voluntates, primum advocent parochie sacerdotem, et coram ipso et aliis idoneis testibus sua legitime ordinent testamenta vel ultimas voluntates"; KDW, vol. 1, no. 487.

6o On the statutes of the chapter of the Krakow cathedral and their sources, cf. Marek D. Kowalski, Piętnastowieczne statuty kapituty katedralnej w Krakowie, in Polska i jej sąsiedzi w późnym średniowieczu, eds. Krzysztof Ożóg, Stanisław Szczur (Krakow: Towarzystwo Naukowe Societas Vistulana, 2000), 233-253.

61 "Ne res clericorum, que bona sunt pauperum, usurpan, aut illicite contractari per manus violentas ymmo sacrilegas valeant laycorum, districte precipimus et mandamus, ut cum presbyter aliquis vel rector ecclesie graviter egrotari percipitur, quod de morte ipsius verisimiliter timeatur, decanus eius sine mora duos vel tres vicinos ad eum dirigat capellanos, qui res eius omnes et singulas diligenter conspiciant et conscribant, ut post eius mortem honeste sibi fiant exequie, et iuxta testamentum eius, quod racionabiliter et legitime 
of conflicts between church authorities and the lay patrons of church institutions, who claimed their right to the property of the deceased clergyman based on a traditional 'right of spoils' (ius spolii). ${ }^{62}$

Eleven years later, Bishop John Grot of Krakow also issued a statute referring to the making of wills in which he instructed that there was no duty more important than the fulfilment of the last will, whether it be that of an ill person or a healthy one, a clergyman or a lay person. The pastor or his deputy were to fulfil the deceased's requests concerning the place of burial, even if it was outside of the parish, and bequests made 'for the soul.' If anyone tried to oppose this, he would be deprived of the right to a Christian burial. ${ }^{63}$ In a statute of

ordinatum existit, per ipsum solvantur debita, que contraxit, et per eum legata legitime dispensentur, pro successore quoque residuum conservetur. Ad cuius sepulturam laudabiliter peragendam, capellani vicarij, qui commode venire poterint, sine contradiccione accedere teneantur. Si quis autem patronus per potenciam secularem de talibus rebus recipere quidquam presumpserit, dictus decanus eum tamdiu auctoritate nostra excommunicet, et excommunicatum faciat per suos subditos publiee nunciari, donec ablata restituet, et pro temeritate commissa satisfaciat competenter. Contra dicentes in una marca argenti per superiorem proximum puniantur"; Statuta synodalia episcoporum Cracoviensium XIV et XV saeculi e codicibus manu scriptis typis mandata additis statutis Vielunii et Calisii a. 1420 conditis (et ex rarissimis editionibus - etiam authenticis - nunc iterum editis), ed. Udalryk Heyzmann, Krakow 1875 (Starodawne Prawa Polskiego Pomniki, 4), 26.

62 This phenomenon was also present on German lands. Gabriele Schulz claimed it was associated with the development of the testament: "Eine sehr starke Einschränkung erfuhr diese Testierfreiheit jedoch durch das sogenannte Spolienrecht, d. h. durch das von verschiedenen Seiten, vor allem von weltlicher Seite beanspruchte Recht, nach dem Tode eines Klerikers dessen Hinterlassenschaft in Besitz zu nehmen. Gegen dieses Spolienrecht wandten sich immer wieder die Synoden. Sie waren bestrebt, »das Kirchengut seiner ursprünglichen Bestimmung zurückzugeben durch den freien Willen der einzelnen Kleriker, d.h. durch Aufhebung desTestamentsverbotes und Gewährung der vollen Testierfreiheit des Klerus über sein Eigentum, auch über das aus kirchlichen Einkünften erworbene Vermögen «. Die meisten Konzile in Deutschland, die gegen das Spolienrecht Stellung bezogen, haben zugleich den Klerikern die größtmögliche Testierfreiheit zugestanden. Es zeigt sich, daß das Spolienrecht letztlich den Ausschlag für die Testierfreiheit des Klerus auch über Einkünfte aus dem Kirchengut gab und damit dem Kleriker die Möglichkeit eröffnete, über sein gesamtes Vermögen frei zu verfügen. Es bestand aber trotz dieser vollen Testierfreiheit der Kleriker die Gewissenspflicht, den aus kirchlichen Quellen erworbenen Besitz der Kirche zu vermachen oder für fromme Stiftungenzuverwenden";eadem,TestamentedesspätenMittelaltersausdemMittelrheingebiet, 8-9.

63 "Quia nichil est, quod magis debetur hominibus, quam ut eorum pija supreme voluntatis eulogia impleantur, igitur statuimus et ordinamus: ut si quisquam clericus vel laycus, sanus vel infirmus, cuiuscumque condicionis existat, pro anima sua aliquid disponere voluerit testamentum, aut testari, seu eciam eligere extra suam parrochiam sepulturam, rectorem parrochialis ecclesie, aut eius vicesgerentem, tamquam personam, que eius 
1331 the Bishop's guardianship was extended to the last wills of clerics as well as laity, to both healthy and sick people (cuiuscumque condicionis existat).

Bishop of Krakow Florian Mokrski treated the issue of the last will in a slightly different manner by insisting on their prior approval by a bishop before their execution. In his synodal statutes of $1373,{ }^{64}$ he addressed the people appointed as executors of wills, who at this time could be either from the clergy or laity. The Bishop declared that he had heard that some executors of the last will had used money and goods intended for pious bequests for other needs. Referring to the sanctions provided for in the 'sacred canons', he stated that both the clergyman and the secular executor of the will should present the will to the bishop within a month in order to obtain his approval. The threat of excommunication was again used against those who tried to oppose this provision. ${ }^{65}$

One interesting statute proclaimed by Bishop Peter Wysz in 1396 referred to persons holding the title of public notary under a papal or imperial appointment. Pointing to the many injustices resulting from the actions of false notaries, he called on all thabellionibus (public notaries) to have their competence confirmed by the bishop's office. At the same time, he also delimited their role as follows: determining the beneficiaries of bequests to the church, courts, transactions, contracts, settlements and wills. ${ }^{66}$ This order seems to

condicionem et conscienciam non creditur ignorare, et que sibi ministraverit ecclesiastica sacramenta, omnino advocet, et ipso presente pro anima leganda et testanda ordinet et disponet, et si voluerit, eligat sepulturam. Per cuius providenciam ipse testator dirigi poterit in hijs, que ad salutem anime sue pertinent, peragendis. Qui vero contrarium fecerit ex contemptu, ecclesiastica in fine careat sepultura, cuius eciam eleccio sit irrita ipso iure"; Statuta synodalia episcoporum Cracoviensium, ed. Udalryk Heyzmann, 40.

64 Bishop John Bodzanta had previously addressed the issue of wills in synodal statutes. However, in his statute De testamentis per prelatos et canonicos Cracouiensis ecclesie faciendis, he only discussed the implementation of the last wills of the prelates and canons of Krakow; Statuta synodalia episcoporum Cracoviensium, ed. Udalryk Heyzmann, 123.

65 "Fide dignis relatibus didicimus, quod nonnulli tam religiosi, quam clerici seculares et layci, pecuniam et alia bona, que per manus eorum testamentis decedencium debent iu usus pijos expendi, non dubitant alijs usibus applicare. Nos attendentes sacrorum canonum sancciones, quibus in omnibus pijs voluntatibus sit per locorum ordinarios providendum, statuimus: quod quocienscumque quisquam clericus vel laycus alicuius testamenti fuerit executor, illud testamentum infra unius mensis spacium nobis presentare fideliter teneatur, nostrum mandatum super execucione huiusmodi recepturus. Alias, si aliqui de bonis ipsis aliquid sibi retinuerint, seu retinere presumpserint, et non secundum voluntatem defuncti ipse distribuerint, testamentumque huiusmodi nobis non presentaverint, ut prefertur, excommunicacionis sentencie ipso facto eos volumus subiacere"; Ibid., 40.

66 "Quoniam in negocijs et causis civilibus aliquando et in criminalibus, et quam plurimum in beneficialibus, in quibus bona fides et iustus tytulus requiritur, ac viciosus ingressus 
have been linked to broader action taken by the Church hierarchy against dishonest, under-educated and false public notaries. Similar acts were issued at that time by the Bishop of Płock, Jacob, and the Archbishop of Gniezno, Nicholas of Kurów. ${ }^{67}$

Similar prescriptions concerning the recognition and fulfilment of wills made by lay persons and priests, both 'in sickness and in health,' were included in the synodal statutes of Archbishop Nicholas Trąba, proclaimed in 1420. In them the Archbishop reaffirmed his earlier defence of the right to bequeath property on one's death bed and his right to act in the role of guardian to safeguard wills in accordance with canon law. ${ }^{68}$

The support for bequests of last will expressed both in the rulings of Piast princes and the Episcopal protection provided for in canon law most certainly played an important role in the spread of wills within and beyond the diocese of Krakow. The growing power of the papacy and the Pope's centralization of

debeat vitari, thabellionibus, tamquam servis publicis et scriniarijs, et eorum instrumentis ac scriptis autenticis, tam in iudicio, quam extra iudicium, in transaccionibus et in arbitrarijs que fiunt eciam ad instar iudiciorum, in testamentis et ultimis voluntatibus ac alijs contractibus diversis, et maxime in acceptacionibus et provisionibus ecclesiasticorum beneficiorum utimur probandis et improbandis"; Ibid., 54 .

67 Agnieszka Bartoszewicz, Piśmienność mieszczańska, 212.

68 "Ad hoc quod quedam in quibusdam partibus consuetudo, ymmo corruptela detestabilis observatur, videlicet quod tam laicus quam clericus, in lecto egritudinis constitutus, ultra certam summam iuxta loci illius consuetudinem limitatam nec piis locis nec personis ecclesiasticis pro anime sue remedio et salute aliqua possit ordinare legata: considerantes licet vicibus iam repetitis predictam consuetudinem et sacris canonibus et secularibus eciam legibus obviare, cum omnia iura clamant, quod ultima voluntas et ultimum hominis testamentum inviolabile perseveret, et nichil sit, quod magis hominibus debeatur, quam quod in extrema voluntate libera facultas existat, eandem consuetudinem Deo odibilem, animabus et moribus bonis inimicam auctoritate huius sacri concilii penitus reprobamus, firmiter statuentes, ut unicuique, quem iura a testamentorum non prohibent faccione, in sanitate vel in lecto egritudinis constituto, legandi, disponendi et ordinandi de bonis sibi collatis circa pia loca et personas ecclesiasticas, dummodo legitimos non pretereat successores, libera sit facultas. Volentes et precipientes districte, ut per locorum episcopos et ceteros prelatos iurisdicionem habentes universi clerici tam religiosi quam seculares et laici, impedientes defunctorum legata seu ultimas voluntates, per excommunicacionum in personas et interdicti in loca sentencias, canonica monicione premissa ferendas, ab huiusmodi impediments desistere compellantur; ad quorum execuciones et deblitas aggravaciones procedentes tempore faciendas episcopi et prelati, ad quos testamentorum defensio utroque iure suadente dinoscitur pertinere, benivolos se exhibeant et paratos, ne huiusmodi negligencia de eorum manibus in die districti iudicii requiratur"; Statuty synodalne wieluńsko-kaliskie Mikotaja Trąy z r. 1420. Z materiatów przysposobionych przez B. Ulanowskiego, eds. Jan Fijałek, Adam Vetulani (Krakow: Polska Akademia Umiejętności, 1951), 54-57. 
the Church's bureaucratic apparatus, which was now able to provide effective support for the wills of not only clergy members, but also of lay people, were clearly also of major importance. The pious bequests contained in wills provided significant income for church institutions, and church guardianship over acts of last will guaranteed that they would be realized in line with the wishes and needs of the Church. It also safeguarded them against usurpation and misappropriation by laypersons, including powerful lords who had founded new private or parish churches and who possessed the 'right of patronage' (ius patronatus), relatives who in the absence of a will would have inherited a greater portion of the deceased's estate, and those chosen as executors of the will, who bore the bulk of the responsibility for the proper fulfilment of the will. The guardianship provided by the bishops of Krakow over wills is at times still visible in the fifteenth and early sixteenth centuries, however at that time they became increasingly secular affairs. There are indications that as late as the fifteenth century, some testators turned to an ecclesiastical court rather than a municipal court to authenticate their last will, placing greater trust in the former. For example, the Krakovian municipal notary John Stolle, when making his will in 1439, pointed out that if municipal councillors could not or did not want to carry out his bequests in full, he passed this duty on to Church authorities in Krakow: the bishop, the chapter and the church court. ${ }^{69}$ The case of Stolle was to some extent exceptional because the testator was an ordained priest, but likewise in the will of the village administrator $(\text { soltys })^{70}$ Peter Filipowski from 146o, it is mentioned that he revoked all his earlier wills, whether made before the bishop's court or elsewhere, before both clergy and laity. ${ }^{71}$

Another example of the Church's maintaining a form of jurisdiction over the provisions of the last will during this period can be found in a document dating from 1483. It is a notarial act drawn up by John, Bishop of Krakow, in which

69 "Item ap desim meyme testament icht hindernis entstunde is were von hern macht, adir von nicht beczalunge der czinse, adir von ander sache wegen, do von vorseumins geschege der gestifen mossen, do wedir dy patronen ratmanen nicht mochten adir nicht wolden, so czye ich alle dese bescheydunge mit foller macht an dy heylige Crakischer kirche an den erwidigen vatir den crakischen Bischoff, und an seyn Capitil, und Official, daz dy dovor raten, daz dis oppir meyner sawirn erbt, gote und seyner kirchen nicht entwand werde"; SCAB. 6, fol. 186 (1439).

70 See Glossary: Village administrator

71 "In primis revocat omnia et quelibet testamenta sua prius per eum sive coram reverendissimo domino episcopo Cracoviensi sive alias ubique facta, coram quibuscumque personis spiritualibus seu secularibus cassans omnia huiusmodi testamenta volens ipsa nullus roboris esse nec vigoris"; LT, fol. 66 (1460). 
he acted as a super-arbitrator in a dispute between the Castellan ${ }^{72}$ of Wojnica, Paul Sborzeński, the executor of the last will of the Castellan of Wojnica's wife, Margaret Ossolińska, and both the altarist John Rusek and Ossolińska's heir, the late Nicholas Łowczowski. ${ }^{73}$ Another interesting document is a slightly later ruling issued by Pope Alexander VI in response to a complaint from the executors of the will of bookseller John Klemesz. In it, the Pope recommended that the Krakovian canons assist in the fulfilment of the will. ${ }^{74}$ Despite these late traces of intervention in support of wills by the Church hierarchy, it can be clearly seen that since the late fourteenth century, secular authorities increasingly treated last wills as falling within their purview, both incorporating them into common law (ius commune) and placing them under the supervision of secular courts, as we will see in the following chapters. ${ }^{75}$

\section{$3 \quad$ Property Laws in Medieval Cities}

The definition of the will contained in canon law clearly contradicted not only Polish land law, which was gradually being codified, but also so-called German town law, which played a crucial role in cities during this time. Like many other cities in the region, Krakow functioned under Magdeburg Law, which it officially adopted from Wrocław in $1257{ }^{76}$ This already highly - though not fully

72 See Glossary: Castellan

73 AMK, Pergamyns., ms 334 (1483).

74 AMK, Pergamyns ms 377 (1503).

75 Paul Szczerbic's book from 1581 states that an infirmed individual cannot make a gift out of "fear of death" because they are no longer in control of themselves and thus "act in violation of the natural right" of their descendants. But he further states that: "Someone could argue against this article, and say that it is not good for many reasons. First, if this right were to be upheld, no man or woman would be able to pass on their possessions to anyone in ill health. No testament could do this. But this cannot be so, because everyone is free to make their own will according to their wishes. For it is stated in the law that if the descendant of the one who made a will does not fulfill it, then a bishop is to gather all the possessions, and to keep them at his disposal until the heir fulfills the wishes of their relative. And if the heir should satisfy the will of the deceased, then they are also free to give it to whomever they wish. The second reason is that this would mean the last will and testament would be rejected, which also cannot be so, because according to the law, everyone's last will is to be strictly observed. If someone gives anything for works of charity, then the descendant should carry out this bequest. And if the heir does not want to do so, then the testament should be executed or fulfilled by the bishop himself"; idem, Ius municipale, 215 .

76 Jerzy Rajman, Krakow: zespót osadniczy, proces lokacji, mieszczanie do roku 1333 (Krakow: Wydawnictwo Naukowe Akademii Pedagogicznej, 2004), 19o-193; Jerzy Wyrozumski, 
- developed and codified legal system consisted mainly of the aforementioned Sachsenspiegel (Speculum saxonum), i.e. a list of common laws from the territory of Saxony (divided into landrecht - land law, and lehnrecht - feudal law) and the Magdeburg Weichbild (Ius municipale magdeburgense), i.e. a collection of laws concerning the municipal political and court systems. If we take into account the fact that three lokators, and later vogts of Krakow, and many other burghers, originally came from Silesia, ${ }^{77}$ and that already in 1308 a Latin version of the Sachsenspiegel (and German version of Weichbild) had been brought to Krakow from Wrocław, translated "for the city and its citizens" by a notary named Konrad of Opole, the initial close link between the legal system of Krakow and that developed in Silesian cities seems unquestionable. ${ }^{78}$

Dzieje Krakowa. Krakow do schytku wieków średnich (Krakow: Wydawnictwo Literackie, 1992), 161-167; Marcin Starzyński, Krakowska rada miejska w średniowieczu, 23-28; Bogusław Krasnowolski, Lokacje i rozwój Krakowa, Kazimierza i Okotu. Problematyka rozwiazań urbanistycznych, in Krakow. Nowe studia nad rozwojem miasta, ed. Jerzy Wyrozumski (Krakow: Tow. Miłośników Historii i Zabytków Krakowa, 2007), 355-426; Jerzy Wyrozumski, Lokacja czy lokacje Krakowa na prawie niemieckim?, in Ibid., 121-151.

Jerzy Rajman, "Mieszczanie z Górnego Śląska w elicie władzy Krakowa w XIV w.", in Elita wtadzy miasta Krakowa i jej zwiazki z miastami Europy w średniowieczu i epoce nowożytnej (do połowy XVII w.). Zbiór studiów, ed. Zdzisław Noga (Krakow: Antykwa, 2011), 49-63; idem, Krakow: zespót osadniczy, 212-218; Jerzy Wyrozumski, Dzieje Krakowa, 171-172.

78 Konrad of Opole, who translated part of the Sachsenspiegel into Latin in 1308, "for the city and inhabitants of Krakow," did so, as he declared, both because he was inspired by God and because he was under orders to do it by the Bishop of Wrocław, so that the rights of the righteous would be protected and the unjust punished. He mentions Eike von Repkow, author of the Sachsenspiegel, but considers emperors Constantine and Charlemagne to be the true lawmakers because they were fulfilling God's will. Konrad of Sandomierz, author of the Latin translation of the Landrecht from the mid-fourteenth century, in contrast, considered the Holy Trinity and the Christian faith to be the true foundation of law. A collection of Chełmno laws dating back to the fifteenth century provides a direct link between the collection of town rights and their true author, God himself. It begins with the words that it was German law that God gave to Moses on Mount Sinai, and ends with the statement that "the words of German law, also known as Chełmno law, and which was spoken by God to Moses." By observing this law, "we can obtain the reward of eternal salvation." The divine authority of codified law and the religious sanctions associated with it are also expressed in the works of other translators and codifiers of urban and earthly laws; it is present in St. Thomas Aquinas' Summa theologica, as well as in the iconography of medieval collections of laws. Placing the image of Christ (initially ruling and later crucified) on the pages of legal codes acted as confirmation of the divine source and authority of the legal provisions contained in the acts. A characteristic example of this is the richly illuminated code of municipal rights created around 1505 by Balthazar Behem with a miniature depicting the crucified Christ; cf. Edward Potkowski, "Autorytet prawa w średniowieczu," in Kultura prawna w Europie Środkowej, ed. Antoni Barciak (Katowice: 
A detailed analysis of the preserved copies of those both sources of municipal law in medieval Poland allowed Maciej Mikuła to stress their mutual complementarity and describe the legal system as Saxon-Magdeburg Law. At the same time, he pointed out that it was Weichbild that played a major role in the legal practice of Polish cities as better suited to urban conditions. ${ }^{79}$ However, both sources of legal code shared many features with traditional customary land law in their statutes governing the family and the rules of inheritance. Family blood ties and kinship played the most important role in both - the goods one possessed were to be inherited and passed on to the next generations in a customary order, "as the blood circulates." 80 The Sachsenspiegel and Weichbild allowed for the alienation of the hereditary estate, but only by an individual in good health who had obtained the consent of their relatives, i.e. by means of an inter vivos act. However, the type of will promoted by the Church allowed for donations also to be made on the death bed, which was expressly forbidden in the Sachsenspiegel, while in the Weichbild it was limited to the symbolic amount of three solidi. ${ }^{81}$ These contradictions and the growing number of disputes in cities between the executors of wills and the legal heirs of the property bequeathed by the deceased, contributed to Pope Gregory XI issuing a bull in 1374 titled 'Saviour of the human race' (Salvator humani generis), in which he condemned 14 articles of the Sachsenspiegel (in the article named 'Against Magdeburg Law,' Contra Ius Maydenburgense), two of which concerned restrictions on the transfer of property. The first allowed for the transfer of movable property only by healthy persons who could hold a sword and shield in their

Instytut Górnośląski, 2006), 15-34; Miniatury z Kodeksu Baltazara Behema, ed. Marcin Fabiański (Krakow: Wydawnictwo Karpaty, 200o).

79 Maciej Mikuła, Prawo miejskie magdeburskie (Ius municipale Magdeburgense) w Polsce XIV-pocz. XVI w. Studium o ewolucji i adaptacji prawa (Krakow: Wydawnictwo Uniwersytetu Jagiellońskiego, 2019), 178 (translated into English as Municipal Magdeburg Law (Ius municipale Magdeburgense) in Late Medieval Poland. A Study on the Evolution and Adaptation of Law (Medieval Law and Its Practice 3o) (Leiden: Brill, 2021)); Zygmunt Rymaszewski, Łacińskie teksty Landrechtu Zwierciadta Saskiego w Polsce: versio Vratislaviensis, versio Sandomiriensis, Łaski (Studia nad Historią Państwa i Prawa, II, 15), (Wrocław: Zakład Narodowy im. Ossolińskich, 1975), 6; idem, "Miejskość czy wiejskość prawa Germanego w Polsce," Zeszyty Naukowe Uniwersytetu Łódzkiego, Nauki HumanistycznoSpoteczne, 69 (1970), 74-75.

$80 \quad$ "Ja naeher dem Blut, desto naeher dem Gut"; Uta Marquardt, "Görlitzer Testamente des 16. Jahrhunderts als Quelle sozialgeschichtlicher Untersuchungen," Neues Lausitzisches Magazin 123, no. 4 (2001), 34 .

81 "De legationibus seu donis in lecto egritudinis. Nemo masculus; nec vlla mulier possent in loco egritudinis de bonis suis alicui vltra tres solidos dare, absque heredum consensus seu voluntate; nec mulier sine consensus mariti"; Jan Łaski, Commune Incliti Poloniae, Libri duo, vol. 1, 179r. 
hands, while the second considered legal only those provisions that were made before a court and had the consent of the heirs. ${ }^{82}$ The reason for the condemnation of the articles was the same: "These articles are erroneous because they prohibit alms, last wills, and pious acts." ${ }^{13}$ Not only did municipal law initially not recognize wills, when it did, it expressed a clear hostility to them: according to the principle that the right to goods is possessed by he who can make use of them - that is, a healthy person - making donations on one's death bed was prohibited. ${ }^{84}$ Moreover, according to the beliefs of the time, "a person's will was extinguished at the moment of death, and thus posthumous bequests could not yield legal consequences." 85 Thus, in the Pope's dispute with Magdeburg city law, his authority served to secure the freedom to bequeath property, ${ }^{86}$ and a list of the condemned articles was included in the codification of the statutes and privileges of the Kingdom of Poland drawn up by John Łaski in $1506 .{ }^{87}$ The papal bull was almost certainly published in the Kingdom of Poland shortly after its publication; for example, it is known that a list of forbidden articles

82 "Tredecimus articulus. Quod quicunque succinctus cum gladio clipeum tenens, non potest de lingo vel lapide pollicis vlnam quantum ad altitudinem habentem supra dextrarium scandere, talis non potest cedere, dimittere, vel infeudare, vel etiam mobilia bona alicui dare sic quod iste custoditus sit qui talia post mortem dantis expectat. Iste articulus est erroneus, inquantum elemosinas, testamenta, et alia pietatis opera prohibit. Quartusdecimus articulus est, Quod nullus sine licentia suorum heredum, sine Iudicio bannito, quod Saxonie dicitur, geheget ding, potest dare proprietatem suam, vel suos homine. Et sit alia daret alicui, heredes acquirent ista per iudicium, acsi dans illa mortuus esset. Isti duo articuli sunt erronei inquantum Elemosinas et alia pietatis opera prohibent"; Ibid., 175r.

83 "Isti duo articuli sunt erronei inquantum Elemosinas et alia pietatis opera prohibent"; Ibid.

84 It was provided for in the thirteenth article of Magdeburg Law, which was supressed by Pope Gregory XI: "Quod quicunque succinctus cum gladio clipeum tenens, non potest de lingo vel lapide pollicis vlnam quantum ad altitudinem habentem supra dextrarium scandere, talis non potest cedere, dimittere, vel infeudare, vel etiam mobilia bona alicui dare sic quod iste custoditus sit qui talia post mortem dantis expectat"; Ibid.

85 Przemysław Dąbkowski, Prawo prywatne polskie, 67.

86 A major role in the Pope's condemning these articles was played by the Augustinian theologian Johannes Klenkok. In 1369, he wrote a work entitled Decadikon in which he condemned 10 articles of the Sachsenspiegel, which, in his opinion, restricted the Pope's power and were in conflict with "Christian law." These arguments were not accepted by the Bishop of Halberstadt, Albert, and in 1370 the municipal council of Magdeburg banished Johannes from the city. In 1372, he sent to Pope Gregory XI in Avignon an extended list of 21 articles of the Sachsenspiegel which he believed to be improper. On 8 April 1364, Gregory XI issued a bull condemning 14 of them; cf. Christopher Ocker, Johannes Klenkok. A Friar's Life c. 1310-1374 (Philadelphia: American Philosophical Society, 1993), 42-69.

87 Łaski's Statutes also include King Alexander's confirmation of fourteen articles of Saxon and Magdeburg Law condemned by pope Gregory XI; Jan Łaski, Commune Incliti Poloniae, Libri duo, part 1, 174-174v. 
was found in a private textbook owned by an inquisitor residing in Krakow in the early fifteenth century. ${ }^{88}$ However, we do not know how it was received, in particular by Krakow's municipal authorities.

The archaic bequests contained in the Sachsenspiegel concerning the ownership of goods did not simply become invalid. Writing down and codifying the law always eventually leads to its petrification, but, as these rules and norms became dated, they and their applications were not simply forgotten. Even that the handwriting nature of the legal codes allowed for a certain range of their modifications and adaptation to the contemporary needs, they definitely could not keep up with much more dynamic social changes ${ }^{89}$ As Henry Maine noticed "When primitive law has once been embodied in a Code, there is an end to what may be called its spontaneous development. Henceforward the changes effected in it, if effected at all, are effected deliberately and from without." 90 Jack Goody described broadly this phenomenon in his book The Logic of Writing and the Organization of Society. He referred, among others, to persuasive comment of Fritz Kern: "In contrast to the positive codified law, customary law 'quietly passes over obsolete laws, which sink into oblivion, and die peacefully, but the law remains young, always in the belief that is old. Yet it is not old... Statute law, on the other hand, cannot be freed from the letter of legal texts, until a new text has replaced an old one, even though life has long since condemned the old text to death; in the meantime the dead text retains power over life.".91

However, the dynamically changing nature of society and living conditions in the late medieval city required a departure from the archaic principles hitherto governing ownership and inheritance. Because capital investments in real estate and its sale were sources of income of the city, its elites needed to make existing rights concerning the ownership of property more flexible. Moreover, growing religious awareness, the influence of Mendicant orders, and the example provided by royal and magnate elite in terms of funding activities, strongly influenced the growing need among townspeople to make testamentary bequests. The above factors also influenced the process of distinguishing

88 "Twenty of the twenty-one articles, first reproved by Johannes Cleynkoc of the Orden of Hermits, and by master Berniger (i.e. Kerlinger) Walther of the Order of Preachers, and by Gregory XI, appear in collection of papal documents added to the handbook of an inquisitor of Krakow in the early fifteenth century"; Christopher Ocker, Johannes Klenkok, 63 .

89 Maciej Mikuła, Prawo miejskie magdeburskie, 179-181.

$90 \quad$ Henry Sumner Maine, Ancient Law, 17.

91 Jack Goody, The Logic of Writing and the Organization of Society (Cambridge: Cambridge University Press, 1986), 127-171. 
acquired goods from the rest of the estate - a phenomenon that had its roots in Polish lands as early as the early thirteenth century, ${ }^{92}$ but which became widespread in urban jurisdictions over the following century. ${ }^{93}$

The division of property between hereditary and acquired goods is also found among the articles of the Magdeburg Weichbild. In an article concerning the principles for making bequests of dowers, it states that "every man who has a house subject to municipal law and in accordance with his last will can donate to his wife as a dower his hereditary goods (priopriam hereditatem), which he has the right to alienate from himself, as well as his other movables."94 In another place in the Weichbild, it clearly states that "[a] man, being in good health, can pass on to whomever he wants only those movables and merchandise acquired through the joint work of the husband and wife." ${ }^{95}$ With time, municipal law in Krakow adopted the principle of the free disposal of all acquired goods. ${ }^{96}$ In bequests found in municipal books, mention of this principle can be found as early as the first half of the fourteenth century. For example, in one record from 1333, councillor Nicholas of Zawichost bequeathed

92 The document transferring the village of Udorz to the Monastery in Miechów in 1232 contains this remarkable statement: "enim dicte uille deuenit ad me tanquam aduenticia, non ad me perueniens ex paterna hereditate, et ob hoc ad suos non transferetur heredes"; KDM, vol. 2, no. 404 (1232).

93 "Only in the late thirteenth century, and initially only in town privileges, did differences develop in the legal treatment of ervengut [hereditary goods - J.W.] and wunnenegut [acquired goods - J.W.] in the Saxon law, adopted later also in land law. In some cases it was influenced by foreign laws, one would assume, considering the so-called 'Wrocław land law,' established in the mid-fourteenth century. Although it was strictly based on the Sachsenspiegel, it deviated from it on the issue of alienation of property, limiting the freedom of the owner to dispose of property without the permission of the heirs only to hereditary property, anirstorben gut. It is very likely that this was due to the influence of Polish law, which in the early thirteenth century, notably in Silesian sources, clearly emphasized the freedom of alienation for acquired goods, eliminating completely the possibility of intervention by the heirs. (etiam invitis amicis)"; Karol Koranyi, Podstawy średniowiecznego prawa spadkowego, 115-118; Cf. Przemysław Dąbkowski, Prawo prywatne polskie, 505.

94 "Etiam quivis vir habens mansionem infra ius municipal, ille sue contorali dare potest pro dotalicio suam propriam hereditatem, quam in posse habeat alienandi; et etiam in alys bonis suis mobilibus inquantum voluerit”; Jan Łaski, Commune Incliti Poloniae, Libri duo..., part 1, 178v.

95 "Si autem vir habuerit bona mobilia; aut mercimonia; que sibi propriis laboribus aut prospera fortuna accreverunt cum sua uxore; illa potest dare in valitudine vite sue cuicunque placet; cuiuslibet sine contradiction de Iure"; Ibid., 183v.

96 "This fragment of the work [...] played a relatively important role in relaxing the principle of the non-transferability of immovable property in the event of death, which later also included free disposal of a certain portion of immovable property, or a certain kind of it"; Karol Koranyi, Podstawy średniowiecznego prawa spadkowego, 64 . 
to the children of his son-in-law Hankon all his goods and the heritage he "acquired through his work" (que et quas proprijs laboribus conquisivit), reserving for himself the right to use them as long as he was alive. ${ }^{97}$ In the latter half of the fourteenth century, one can observe the growing prevalence of declarations concerning the possession of goods acquired through one's work, as a means of ensuring one's freedom to dispose of them by means other than the principle of 'the circulation of blood. ${ }^{98}$ In a bequest from 1371, John of Eger asks the municipal tribunal whether he could dispose of all of his goods in accordance with his will, since he had acquired them through his work. The tribunal replied in the affirmative. ${ }^{99}$ In the following years, similar questions appear more and more often on the pages of the books of municipal bench court, which led to their being shortened into a universally applicable form. For example, at the beginning of a bequest from 1395, there is only the following short note: Mathias Breunchin requisivit in sentenciam etc... "Mathias Breunchin applied for the verdict etc."100 which would be incomprehensible

97 "Eodem Anno et die Nycolaus de Zawichost coram iudicio bannito constitutus dedit et contulit pueris Hanconis dicti Zawichost generi sui omnia bona sua ac hereditates, que et quas proprijs laboribus conquisiuit, iure hereditario. Hijs enim bonis et hereditatibus iamdictus Nycolaus de Zawichost pueris predictis datis et resignatis coad uixerit, frui debet"; NKiRMK, no. 1141.

98 For example, in 1368 the alderman Nicholas Essenbach declared that all his property had been acquired through his work, so he ordered it to be passed on to his wife and her appointed guardians: "Nicolaus Essenbach constituit procuratores Nicolaum Stolczel (et) Nicolaum Grobnik uxoris sue et bonorum suorum omnium et requisivit in sua diffinicione, ex quo omnia bona sua suis acquisivisset laboribus et hoc facto omnia dicta bona sua, in quantum prius ea moriretur, debet hereditarie super lucro et dampno ad tempora vite sue possidere, preter $\mathrm{L}$ mrc, que debent couterinis suis assignare, ipsa vero domina defuncta et bonis remanentibus eiusdem, domine filie sue Margarethe aut heredibus eius, preter XX mrc, que debent eidem domine Margarethe filie, alie X mrc. Debent assignari, residuum autem, quod fuerit, dicti tutores debent converti in usus infirmorum hospitalis, si vero fieri poterit ad pretorium Capelle debent assignari, isto expresso, quod dicta domina Katherina Petrum filium sororis sue circa se sibi ministrandi vite necessaria pro suo posse in quantum ipsam et scolas sequi voluerit ac sacros presbiteratos ordines mutari et ipsum in libris suis cum $\mathrm{X}$ mrc, volens dictus Nicolaus esse dominus bonorum suorum"; SCAB., no. 242 (1368); cf. Jacek Laberschek, Mikotaj z Zawichostu, in PSB, vol. 21 (Wrocław-Warszawa-Krakow: Polska Akademia Nauk, Polska Akademia Umiejętności, 1976), 152.

99 "Johannes de Egir requisivit a scabinis sentencialiter, ex quo omnia sua bona suis acquisisset laboribus, utrum cum eisdem posset facere, prout vellet; sentenciatum fuit hec posse fieri, ubi ipse domum in platea Castri contiguam domui Peszconis medici Petro Jordansmol perpetue resignavit"; SCAB., no. 603 (1371).

100 "Mathias Breunchin requisivit in sentenciam etc. tandem idem Mathias Breunchin omnia bona sua, que habet et habiturus fuerit, domine Margarethe conthorali sue legitime post 
without knowing the context of this entry. The development of a permanent distinction between movable and immovable goods in the consciousness of Krakovians is also evidenced by the mention of the transfer of "all movable goods, hereditary property and immovable" (omnia bona sua mobilia, hereditaria et immobilia), ${ }^{101}$ and by a later clause which reads "all goods provided that they have been achieved through one's work."102

In the ortyle ${ }^{103}$ (German urteile) i.e. judgements and legal clarifications of Magdeburg Law, ${ }^{104}$ translated into Polish in the fifteenth century, the burghers' doubts about whether they could dispose of their goods is addressed as follows: "A man can give his inheritance and all legally acquired goods to any person or to the church, or wherever and whenever he wishes in his will, and this is allowed by law."105 The Magdeburg councillors' response is convincing evidence of the significant expansion of both the category of acquired goods and the right to dispose of them, which included wills at this point in time. Given the fact that these recommendations were addressed to burghers, who had often come to Krakow as immigrants and carried out numerous real estate transactions in the city, it is easy to imagine that in many cases the acquired goods could include almost all the property they possessed. Bequests concerning the transfer of property after the death of its owner, large numbers of which have been preserved in Krakow's municipal books, prove that the burghers often exercised this right.

mortem suam habenda cum plena faciendi et dimittendi facultate donavit, exclusis tantummodo C mrc. gr. prag., que statim post obitum ipsius in opera pietatis converti debebunt per subscriptos tutores et ipsa domina suum dotaliciuin renuncciavit; reservat dominium: tutores sunt: Swarczpeschko et Dauid Gunthir"; SCAB., no. 2155 (1395).

"Cristan murator omnia bona sua mobilia hereditaria et immobilia, que habet ad presens, domine Cristine consorti sue legitime libere contulit et donavit”; SСАв., no. 1579 (1392). "Albertus de Auswinzin omnia bona sua, que elaboravit seu elaborabit, Katherine uxori sue cum faciendi et dimittendi facilitate resignavit”; SCAB., no. 1976 (1394).

103 See Glossary: Ortyle

104 In publishing these judgements, Michał Wiszniewski wrote: "In the library of the Academy of Krakow I found two collections, quite different from each other, of such judgments, or Urteils in German, written in the early fifteenth century at the latest. Apart from these two collections in the German language, I own a manuscript of a collection of judgements by jury members specializing in Magdeburg Law in the Polish language, rewritten by one scribe in 1501, as evidenced by his signature in red ink at the end, without any internal chronology. I compared these Polish judgements, with no specific dates, published here entirely in appendices, with a copy of the same Polish judgements made in 1533. This last manuscript with a slightly different spelling, with some German influences, is faithful to the original copy; it even repeats all its mistakes, and adds new, very serious ones"; idem, Historya..., 154-155.

Ibid., 244. 
Apart from the influence of the Church and the spontaneous development of municipal law, a third factor that played a significant role in the spread of the will in Krakow was Roman law, traces of which can be seen in the theory of civil law and in the practices of municipal courts. Of course, this did not concern classical Roman law, but "the medieval composition of glossaries and commentaries, for which the starting point was (often a misreading of) the Code of Justinian (Codex Justinianeus)."106 The study of Roman law at European universities encouraged the incorporation of its concepts into the codification of local laws. At the University of Krakow, restored in 1400, Roman law was taught in as many as five faculties (i.e. the same number of faculties in which the liberal arts and medical sciences were taught). ${ }^{107}$ There are echoes of some Roman law concepts in the Sachsenspiegel itself, although here they are of rather marginal significance. ${ }^{108}$ However, the application of Roman law is barely perceptible in the documents created by municipal offices at that time, so it is difficult to state with confidence the extent to which the Sachsenspiegel reflects the influence of ius civili on municipal court systems, and to what extent these legal practices are unrelated.

The traces of the adoption in Krakow of principles taken from Roman law were fourteenth- and fifteenth-century glosses to Magdeburg. ${ }^{109}$ However, the most important source of information came from Raymund Parthenopeus' treatise on law titled Summa legum brevis levis et utilis, written in the latter half of the fourteenth, or the early fifteenth, century. It is a concise lecture on the system of Roman law with some elements of canon law. Summa had a major influence on the practices of municipal courts, especially in cases that were not regulated in the Sachsenspiegel. ${ }^{110}$ It was included in John Łaski's codification of 1506 because, in his opinion, it had long been considered an authoritative source in Polish towns and cities. ${ }^{111}$ Łaski's opinion is confirmed by extant

106 Krystyna Bukowska, Orzecznictwo krakowskich sądów wyższych w sporach o nieruchomości miejskie (XVI-XVIII w.) (Warszawa: Państwowe Wydawnictwo Naukowe, 1967), 12.

107 Adam Vetulani, Z badań nad kultura prawnicza w Polsce piastowskiej (Wrocław: Zakład Narodowy im. Ossolińskich, 1976), 207.

108 Krystyna Bukowska, Orzecznictwo, 12.

109 Ibid., 9.

110 This was the task of Roman law according to the fourteenth-century gloss by von Buch; $\mathrm{cf}$. Ibid., 13 .

111 "[...] quia eorum practica communiter fit in certis nostris locis ius Maidemburgense ac Theutonicum habentibus"; Jan Łaski, Commune Incliti Poloniae, Libri duo, part 1, 175. 
sources. ${ }^{112}$ There is ample evidence indicating that this work may have possibly been produced in the Kingdom of Poland, including the fact that the largest number of known surviving manuscript copies of Summa are located within the territory of the former kingdom. ${ }^{113}$ One of the copies is in the possession of the municipal council of Poznan, ${ }^{114}$ while another is found in the Liber legum code, stored in the Przemyśl city archive. ${ }^{115}$ Dr. Raymund's work was most likely also known in Krakow, ${ }^{116}$ and the legal regulations it contained could have been used by the local municipal judiciary. ${ }^{117}$ Perhaps some representatives of the Krakow ruling elite, who would have had the education necessary to read it, might also have possessed copies of the work. ${ }^{118}$

Although there are no direct references to the principles of Roman law in the bequests in Krakovian council books or books of the municipal bench court, an analysis of the entries in these books allows us to see gradual changes in the basic concepts related to civil law (such as the nature of ownership of goods or the categories and laws relating to them). ${ }^{119}$ Over the course of the slow process of transformation in these laws, one can observe:

a desire to strengthen the position of the owner. The first step on this path was to move away from the German concept of wielding, which blurred the differences between ownership and other rights to things, in favour of

112 Adam Vetulani, "Fragment Summy Rajmunda w rękopisie warszawskim," Czasopismo Prawno-Historyczne 14, 1962, no. 2, 165-172.

113 Krystyna Kamińska, "Summa Rajmunda Partenopejczyka jako zabytek średniowiecznego prawa polskiego," Czasopismo Prawno-Historyczne 26, 1974, no. 1, 147-157.

114 It belonged to Matthias, a pharmacist, alderman and councillor from Poznan; Witold Maisel, "Poznanski rękopis Summy Rajmunda Partenopejczyka," Czasopismo PrawnoHistoryczne 12, 196o, no. 2, 135-149.

115 According to Anna Łosowska this code: "had various functions. It could have been a convenient textbook for students, an interesting read for an educated clergyman, but also for a townsman who could write. It also might as well have served as a legal code kept on hand both in the municipal tribunal and in the municipal bench court." eadem, Kolekcja 'Liber legum' i jej miejsce w kulturze umystowej późnośredniowiecznego Przemyśla (Warszawa-Przemyśl: Archiwum Państwowe, Przemyśl; Naczelna Dyrekcja Archiwów Państwowych, 2007), 258-269, 337.

116 "Raymundus Parthenopeus iuris utriusque doctor"; Jan Łaski, Summe Raymundi de Iure, in idem, Commune incliti..., Registrum.

117 Anna Łosowska, Kolekcja 'Liber legum,' 26o-261; Bożena Wyrozumska, Kancelaria miasta Krakowa w średniowieczu, 102.

118 For example, counselor Stanisław Leymitter left three legal books; we also know that Herman, a doctor, kept his book collection in a locked chest, cf.: cons. 429, fol. 368 (1465), CONS. 428, fol. 520, 534 (1449).

119 Krystyna Bukowska, Orzecznictwo, 33-36, 6o-63, 109-113. 
Roman notions, which, by considering possession as a factual state corresponding to ownership, emphasized its independent and superior nature [...] The same objective is served by a progressive restriction of third parties' rights to immovable property [...] The adoption of the Roman theory of ownership is also linked to the restriction of the husband's rights in relation to the wife's property and of the guardian over the property of persons under his care. ${ }^{120}$

It seems, therefore, that the relationship between Krakow's municipal authorities and burgher last wills should also have been shaped by Roman law. The provisions on wills contained in Raymund Parthenopeus' aforementioned Summa, in which an exceptionally large amount of space is devoted to 'testaments,' provide valuable data in regard to this question. It provides definitions of wills and bequests and answers questions about who could make a will, what goods could be disposed in one, what part of a will a person had at his disposal, how many witnesses one needed to have, and who could act as a witness, as well as explaining the reasons for drawing up a will and how to write one. ${ }^{121}$

However, the explanations the Summa provides are somewhat ambiguous. For example, it states that "a will is the lawful disposition of one's goods after death in accordance with one's free will and common sense, and the appointment of an heir to them."122 Summa here invokes the Roman principle of nemo pro parte testatus - nobody can inherit only part of an estate. The heir designated to receive the entire patrimony was in this sense expected to take the place of the deceased. ${ }^{123}$ As defined in Summa, a will was limited to the transfer of a person's entire estate to a single individual, and a change in the provisions contained in the will was possible only as long as the testator was living. Bequests made orally, as well as those written on a plate, paper or parchment, with signatures or seals of witnesses, were all considered valid. ${ }^{124}$ Yet,

$120 \quad$ Ibid., 109-110.

121 Jan Łaski, Summe, no. 44-53, 6o-61.

122 "De primo testamentum est voluntatis libere et sane mentis iusta sententia de eo quod quis post mortem suam fieri vult cum institutione heredis"; Ibid., no. 44.

123 "Dixi de eo quod quis post mortem suam fieri vult; scilicet de universo patrimonio; quia nemo potest in parte testari; et quia ante mortem nemo potest sibi ex aliquo testamenti ius vendicare, dixi cum heredis institutione; quia heredis institutio est caput et fundamentum totius testamenti Et est institutio alicuius in locum suum statutio, qui persona defuncti et heredis una censetur"; Ibid.

124 "Due autem sunt species testamenti; una dicitur nuncupativa que sit per verba, alia inscriptis vel per instrumentum. Sed non est differentia si scribatur in tabulis vel papyro 
the above definition, taken directly from ancient Roman law, clearly differed from late medieval urban practices, a fact of which the author of the treatise must have been aware. A trace of such an awareness can be found in a section titled 'On the Solemn Will' (De solenni testamento). ${ }^{125} \mathrm{He}$ states that "according to the law [Roman law], there should be seven witnesses at the solemn will, who will sign it or affix their seal to it." Further on, however, the Summa distinguishes a 'private' or 'simple' will, a concept unknown to Roman law, for which only three witnesses are required for it to be recognised. He also mentions that canon law requires just two or three witnesses, indicating that any will could be made before just two or three witnesses. He also states that it is sufficient to have just one stamp - that of a prince or a city - affixed to the will for it to be considered credible.

Worth attention also are the rules for bequests contained in the section titled 'How Much Can Be Bequeathed' (quantum testari possit), which invoke an institution found in Roman law, that of a 'reserved share' of the estate, guaranteeing the right of heirs to receive a certain part of the deceased's estate. ${ }^{126}$ In accordance with 'natural law' (de iure naturalis), if the father had four or less children, they were to divide equally one third of the estate, and if there were five or more children, they were to divide one half of all the deceased's goods among themselves. The remainder of the estate was considered the property of the father because he had acquired it through his own work. If he died without a will, this part of his estate was to be designated for pious bequests to benefit his soul. After citing these Roman and canonical principles, the author of Summa, however, stipulates that the rules applied should be in accordance with local customs:

There are different customs in different places. There is one custom that a testator who is ill in body, but healthy in mind can freely dispose of his or her moveable goods. His real estate is divided equally between himself, his wife and all his children - and this is a good practice. There is

vel pergameno dummodo testibus signetur vel sigillis muniatur"; Ibid.

125 "De solenni testamento. In solenni testamento debent esse secundum leges septem testes viri honesti qui manibus suis se subscribant, vel sigilla sua appendant. Sed in privato et in simplici testamento requiruntur tres testes. Secundum vero canones duo vel tres, et in hac parte legibus derogatur que duo vel tres testes in omni testament suffitiunt. Si autem sunt proles tanto melius honestus et manifestius. Sufficit tamen aliqui in testamento unum Sigillum principis vel civitatis pro corroboratione testamenti. Et si sigillum propinquorum possit in testamento haberi esset utile et honestium Si vero non tunc extraneorum Sigilla suffitiunt ad eius firmitatem"; Ibid., no. 5 1.

126 Krystyna Bukowska, Orzecznictwo, 99. 
another custom that a person can dispose of all his goods as he chooses, bequeathing more to one and less to another, though none of the children should be disinherited without cause. If [the] testator's children are adults, they should personally express their consent. Another custom says that goods which have been inherited from one's uncle, father or mother cannot be disposed of through a will, though personally acquired goods can be transferred by such means. There is another bad custom that a testator who is ill in body, but healthy in the mind cannot make a will. This violates all sense of justice, as in making a will one does not need a healthy body, but a healthy mind and good intent. ${ }^{127}$

In Krakovian wills one can see traces of all the customs mentioned above, apart from the last, which was condemned by both Raymund and Pope Gregory XI. ${ }^{128}$ When drawing up deathbed wills, some burghers sought to limit their bequests to transfers of money to selected individuals and church institutions. ${ }^{129}$ There were others (most often those without children) who, bedridden by illness, bequeathed their property to their wives, other relatives, or the Church. ${ }^{130}$

127 "Lex precepit liberis legittimis et naturalibus certam quantitatem rerum testari, quasi de iure naturalis eis debeatur. Hoc modo, si quattuor sunt aut pautiores tertiam partem omnium hereditatum, Si vero quinque sunt aut plures, tunc habebunt mediam partem totius paterne hereditatis, Reliqua substantia tota stat in voluntate patris usus, Quattuor aut infra dat natis iura trientem. Semissem vero dant natis quinque vel ultra. Arbitrium seruitur substantia cetera patris. Et non immerito, que ipse eas res elaboravit, ymmo si intestatus decederet. Adhuc anima sua partem suam habebit. Et nota quod semissem vel trientem isti nati debent inter se dividere, ita quod nulla iniuria fiat, et in his legatis debet consuetudo provinciarum servari, Sunt enim in diversis regionibus diverse consuetudines, Est tamen una consuetudo Quod testator sanus mente licet eger corpore de rebus mobilibus liberis suis secundum suum velle disponit. Res autem immobiles equaliter dividit inter se et suam uxorem, et cunctos liberos suos. Et est bona consuetudo, Est et alia consuetudo, Que de cunctis rebus suis potest disponere, prout vult uni plus alteri minus, uni hoc, alteri illud sic tamen quod legittimos liberos non debet sine causa exhereditate, in hereditate privare, vel preterire. Si autem habet puberes filios illorum consensus debet de honestate adesse. Alia iterum est consuetudo, Quod quis de rebus que perveniunt ab avo, vel a patre vel a matre liberis inuitis nihil testamentaliter disponeree potest. De rebus vero provectitiis vel adventitiis prout vult disponit. Est alia mala consuetudo, quod testator langvens corpore licet sit sanus mente bone racionis et mature delibereationis testamentum facere non possit. Quod est contra omnem iustitiam, quia in testamentis fatiendis non requiritur valitudo corporis, sed mentis sanitas et valitudo rationis"; Jan Łaski, Summe, no. 5 o.

128 In bulla Salvator humani generis from 1364; Jan Łaski, Commune Incliti Poloniae, Libri duo, part. 1, 175r.

129 E.g. CONS. 428, fol. 305 (1431).

130 E.g. LT, fol. 153 (1493). 
Traces of efforts to observe statutory provisions on the inheritance of hereditary property can be seen in, for example, challenges made to the act of last will of the councillor Stanisław Weingart. The last will, according to which the house and all other goods were intended for opera pietatis (a bequest 'for the soul'), and the sister of the deceased Osanna was completely disinherited, was challenged by this sister and her husband, the noble Bartholomeus of Górka, a notary for the land court in Krakow. ${ }^{131}$

One more section in the Summa on wills is worth quoting: "The Reasons Why Wills Are Made' (Quare fiunt testamenta). The author first states that: "wills are made so that there are no quarrels or doubts about the legacy left after the testator's death." He then adds that "it often happens, however, that they lead to even greater hostility and murder." He goes on to quote the reasons that can motivate testators: "There are thus wills for holy places, for the salvation of their souls. They are also for wives, out of marital love. ${ }^{132}$ They are also for children due to natural obligations towards them. They are also for relatives because of the union of blood. They are for the poor for the glory of God. They are also for servants for their service, etc."133

The reasons given by Raymund indicate that in his observations he distanced himself from both the classic perception of the will as an efficient tool for transferring control of one's estate to the chosen heir, and from the role prescribed to the will by the Church as an act securing for the deceased a path to salvation. The author of Summa was even critical of the very idea of a will, arguing that (perhaps unsurprisingly) it led to conflicts and even murders within the family. This remark, along with evidence from local customs (very close to practices known from Krakovian wills) prove that Raymund Parthenopeus had a good understanding of how the will functioned in the late

131 "Eodem anno sabato crastino sancte Barbare dominus Bartholomeus de Gorka tutorio nomine uxoris sue iam secundo arrestavit presens testamentum"; cons. 428 , fol. 406 (1439).

132 In his last will of 1494, salt-mine manager Michael Godzek left all his possessions to his wife Dorothy because she "worked faithfully with him and supported and served him with care and conscientiousness..." A year later, councillor Stanisław Przedbor similarly bequeathed all his possessions to his wife, because she "lived with him faithfully for 40 years in harmony and love"; LT, fol. 154-155.

133 "Quare fiunt testamenta. Testamenta fiunt, ne lites et controversie de hereditatibus a defuncto relictis post mortem testatoris oriantus, que tamen ut frequenter fiunt, ymmo qnandoque magne inimicitie et homicidia ex illis sequuntur. Fiunt etiam testamenta piis locis propter animarum salutem. Fiunt et uxoribus, propter coniugalem amorem. Fiunt filiis propter naturalem obligationem. Fiunt et propinquis propter sangvinis unionem. Fiunt pauperibus propter deum. Fiunt et famulis propter eorum obsequium etc."; Jan Łaski, Summe, no. 5 o. 
medieval city. However, the legal principles cited by him could also accurately depict the rules regulating the writing of wills wherever local city and land laws were silent about them, including fifteenth-century Krakow.

The legal regulation of wills in Krakow began only after the approval by Sigismund I the Old of the city's municipal statutes (Willkür) in $1530 .{ }^{134}$ These statutes included an article guaranteeing spouses full freedom when making mutual bequests and an article containing the rules that applied to burghers when drawing up wills. All forms of wills previously deemed acceptable were recognised; this included both 'open' wills - personally witnessed by members of the municipal council or municipal bench court - and 'closed,' sealed wills brought to the municipal authorities for validation, as well as both wills made by healthy individuals and those made on the testator's deathbed. All provisions that were not in breach of the law had to be fulfilled. If any of the will's provisions was held to be contrary to the city's laws or ordinances, then only these parts were to be declared invalid, while the rest of the will should be executed. Although these privileges allowed only for movables to be disposed of on one's deathbed, they also allowed for the bequeathing of sums of money which were secured with real estate located within the city, which in practice allowed for the disposal of real estate in wills. An exception was also made for wills drawn up during times of plague, when the municipal administration did not function normally. It was possible at such times to confess one's last will before two or three members of a guild or other respected and trusted persons. After the testator's death, the witnesses were then to certify the will before the municipal council or bench court. The canonical requirement for two or three witnesses was thus limited to exceptional situations such as periods when a plague was in the city. Other wills were to be authenticated by a municipal bench court or council. This secularisation of wills and the laws regulating

134 The principles for bequeathing property were regulated in Hungary as early as in 1440. For the seven most important royal cities a code of rights, the Codex authenticus iuris tavernicalis, was issued at that time. Among other provisions, it provided for considerable freedom in disposing of one's acquired property and transferring inherited property to one's wife and children; cf. Codex authenticus iuris tavernicalis, ed. Martin Georg Kovachich (Buda: Kilian, 1803), 221-235; Katalin Szende, Testaments and Testimonies. Orality and Literacy in Composing Last Wills in Late Medieval Hungary, in Oral History of the Middle Ages. The Spoken Word in Context, ed. Gerhard Jaritz, Michael Richter (Krems: Medium Aevum Quotidianum; Budapest: Dept. of Medieval Studies, Central European University, 2001), 51; Prawa, przywileje i statuta miasta Krakowa (1507-1795), vol. 1, ed. Franciszek Piekosiński (Krakow: Akademia Umiejętności Krakowskiej, 1885), no. 43, 59-64. A later translation of this act was published by Karol Mecherzyński; idem, $O$ magistratach miast polskich a w szczególności miasta Krakowa (Krakow: D. E. Friedlein, 1845), 199-211. 
them was also evident in the last article concerning them, which imposed sanctions on those who sought to challenge legally drafted burgher wills. From this point on, such individuals were to be punished for violating common law.

The description of wills in Bartłomiej Groicki's Titles of Magdeburg Law [Tytuty prawa magdeburskiego, ${ }^{567}$ ] is accompanied by a reference to a gloss to Magdeburg Law (published by Nicholas Jaskier in 1535), which states that:

Common law thus instructs how to make a will: When someone wishes to bequeath his goods, it is necessary that he should do so in good health, and that it should be written in the presence of seven witnesses, to whom he would declare his wishes and confer his trust. Such a decision shall have force, and the witnesses to his wishes shall testify under oath, if necessary, before a court or some municipal office. ${ }^{135}$

Groicki then notes that: "In the making of wills, Krakovians follow a different custom. For a will to be valid, it must be made before an open court [sad gajony] or council office." He also states that:

And in many other cities, and generally everywhere, a system circumscribing wills is followed, that it is not made before witnesses. And it is better and safer before an office than before witnesses. Because an office, regardless of what happens, usually records the testament in its books or keeps it in its coffers (if it is submitted closed) until the death of the testator. And so even if some of those in the office die, the testament will be realised by others working in the deceased's position. If witnesses or anybody else die, nobody can take their place. ${ }^{136}$

He later paraphrases the entire contents of Krakow's municipal statutes of 1530.137 According to Krystyna Bukowska, "Groicki's contribution was popularising the legal customs and regulations in force in Krakow, including the municipal statutes of 1530, which brought important changes in the area of inheritance law. Perhaps it was due to Groicki's publication of the municipal statutes that they became a model for other cities, which is often emphasized by Krakow's higher court in its case law."138

\footnotetext{
135 Bartłomiej Groicki, Tytuty, 178-179.

136 Bartłomiej Groicki, Tytuty, 186.

137 Bartłomiej Groicki, Tytuty, 187.

138 Krystyna Bukowska, Orzecznictwo, 108.
} 
In codifications of laws in the fifteenth and sixteenth centuries, there is a clear shift in how authority and oversight is exercised in regard to wills. While in the fourteenth century, power was exercised under canon law by the bishop, who could threaten excommunication as punishment for those who challenged wills, by the end of the fifteenth century, this offence began to be treated as a violation of public law. Just as Raymund had done earlier in his Summa, Bartłomiej Groicki, in the article 'The Testamentary Item to Which the Law Belongs,' confirms that a will "made before any secular office does not belong to church law, no one should have to answer for such a will before an ecclesiastical court, but in this law there should be reasonableness before which the will has been dropped."139

By the end of the fifteenth century, the will, which had previously been a religious act, had become a secular act under secular authority. According to Magdeburg Law, the municipal council was still forbidden to issue laws affecting canon law, ${ }^{140}$ which probably resulted in a lack of municipal statutes regulating the principles for making wills in the fourteenth and fifteenth centuries. ${ }^{141}$ It was not until the first half of the sixteenth century that the customs concerning wills were confirmed in Krakow. This transformation took place gradually, and the process itself can be observed only by analysing a broad span of time over two centuries. However, a more complete adoption of the principles of Roman law in the early sixteenth century enabled secular authorities to normalise the rules concerning wills in the light of common law (ius commune). It also made it possible to assert control over those legal acts that were often used to transfer both huge sums of money and large parcels of urban real estate, whose fate (and especially the taxes paid from them) for understandable reasons aroused particular concern among the municipal authorities. The rivalry between the Church and municipal authorities over the supervision of wills can be seen in the statutes of other cities in the region, for example, the Poznan municipal statutes. Even before 1462, it was forbidden for burghers in the city to make last wills in an ecclesiastical court (iudicium spirituale) on

\footnotetext{
139 Bartłomiej Groicki, Tytuty, 190.

140 "Was geistlich recht antrit und wertlich recht nicht ruret, do mogen sy nicht willekure uff seczen"; Die Magdeburger Fragen, ed. Jacob-Friedrich Behrend, Berlin 1865, I, 1, 11, as cited in Michał Patkaniowski, Krakowska rada miejska w średnich wiekach (Krakow: Towarzystwo Miłośników Historii i Zabytków Krakowa, 1934), 115.

141 The nature and the scope of the privilege the municipal council of Krakow refers to in the will of Gotfryd Fattinant are unknown: "secundum tenorem literarum Ciuitatis priuilegiarium”; KDWac., vol. 2, no. 396, 182-185 (1393).
} 
pain of a penalty of 100 grivna, ${ }^{142}$ and in 1540 , it became illegal to draw up a will with the help of public notaries, who were most often members of the clergy. ${ }^{143}$ A similar rivalry is reflected in the decrees of the municipal council of the Hungarian town of Sopron. According to a municipal statute from 1418, wills made in the presence of clergy (as witnesses) were no longer to be considered valid. ${ }^{144}$

\section{5 Property Bequests and Canonical Wills in Fourteenth-Century
Krakow}

The earliest known dispositions on the proper division of property after the owner's death, usually among members of the immediate family (i.e. post mortem donations), can be found on the first pages of the oldest surviving municipal book in Krakow. The oldest known testamentary disposition of this type was made by Wenzel Tschartek (Wacław Czartek) in 1302. He donated half of his house ( $h o f$ ) to his wife Juta, and the other half to his four children. ${ }^{145}$ These donations reflect the gradual evolution of the rules concerning the right of ownership and the rules of inheritance and for making donations under Magdeburg Law. ${ }^{146}$ The forms and names of these bequests varied. In German they were often referred to as Schikung, Vormackung, Geschefft, Gestifte or Ordnungett, ${ }^{147}$ and thus by means of expressions that indicated their private,

142 "Item quicunque civis testamentum aliquod in agone sua, sive in sanitate sua, facere voluerit, ille non debet istud in iudicio facere spirituali, sed civili iudicio, coram consulate seu advocato et scabinis. Qui contra hoc fecerit, luet civitati centum marcas irremissibiliter"; Wilkierze poznańskie, vol. 1, Administracja i sądownictwo, ed. Witold Maisel (Wrocław-Warszawa-Krakow: Instytut Historii PAN, 1966), no. 59, 15-16.

143 "Testamente non coram officio civili, sed notariis publicis facta, irrita, inaniaque esse, a rege Sigismundo confirmatur"; Ibid., no. 98, 31-32.

144 Katalin Szende, Testaments and Testimonies, 55.

145 "In disem selben dinge gab her wenzla Tschartek siner vrowe vern Iuten sinen hof halp, vnde daz ander halbe teil sinen kinden die her mit ir hat: claren vnde Nicolaus vnde Iohannes vnde Katherinen"; NKiRMK, no. 13.

146 Otto Loening, Das Testament im Gebiet des Magdeburger Stadtrechtes (Breslau: M\&G Marcus, 1906), 23.

147 "Neben diesem aus dem römischen Recht stammenden Ausdruck testamentum kennen die deutschen Quellen des Magdeburger Rechtes eine ganze Anzahl deutscher Wörter für einseitige Verfügungen von Todes wegen. Am häufigsten findet sich der Ausdruck »bescheidung«, »bescheiden«. Ja es scheint, als ob dieser Ausdruck als technischer für testieren allein gebraucht worden ist; es ist mir jedenfalls keine Stelle bekannt, in der »bescheiden« auch von einer Vergabung gesagt wird. Ferner finden sich zur Bezeichnung von Testamenten Ausdrücke wie »schikung«, »vormackung«, »geschefft«, »gestifte«, »letzter wille«, »ordnungett« auch »seelgerethe« wird allgemein für Testament nicht nur 
semi-contractual nature. The books in which these bequests were made were referred to as Gemächtebüche. ${ }^{148}$ Pious bequests not described in the sources as wills are described by means of expressions that still make reference to wills: Letzte wille 'last will' ${ }^{149}$ and Seelgerethe 'bequests for the salvation of the one's soul.'150

Donations authenticated before a municipal bench court were used to transfer real estate to a spouse, children and, less frequently, to other relatives or the Church. It can be noted that, like Wenzel Tschartek's bequest, the oldest donations most often initially took the form of inter vivos bequests. Thus, in 1305, a woman named Merkelinne transferred her property to her four children before a municipal bench court. ${ }^{151}$ A year later, a councillor known as Petzcholt von Rosenoue did the same, granting his two children 100 grivna each and half of his house. ${ }^{152}$ Soon after, post mortem bequests began to appear in the oldest municipal book, the beneficiaries of which most often did not receive any inheritance from the wife's estate. For example, in three consecutive bequests made between 1314 and 1317, Tylus of Apkovicz, who was healthy in both body

für fromme Stiftungen verwendet. Auch Ausdrücke wie »bedenken« oder »geben an seinem letzten ende« oder »sin ding berichten« oder »setzen«, und andere mehr werden von einseitigen Verfügungen von Todes wegen gebraucht. Man darf jedoch nicht glauben, dass alle diese Ausdrücke nur für einseitige Verfügungen von Todes wegen angewendet werden. Wie man mit testamentum sowohl einseitige wie zweiseitige Verfügungen von Todes wegen bezeichnete, so verstand man unter den meisten der angegebenen Wörter ebenfalls nicht nur einseitige Verfügungen von Todes wegen. Viele von ihnen finden wir auch bei den Vergabungen wieder"; Ibid., 34-35.

148 "Testaments- bzw. Gemächtebücher existierten hingegen in Städten des deutschsprachigen Raums wie Konstanz, Bern, Zürich, den österreichischen Kleinstädten und besonders Wien. Im Gegensatz zu der Überlieferungsform in Einzelurkunden bieten diese Testamentsbücher eine vollständige und lückenlose Dokumentation der Testamente eines bestimmten Zeitabschnitts. Neben diesen Formen der Testamentserrichtung sind vereinzelt Bürgertestamente in Notariatsregistern und Offizialatsakten überliefert worden"; Brigitte Klosterberg, Zur Ehre Gottes und zum Wohl der Familie, 45; cf. "Ein Großteil der Eintragungen im Gemächtebuch I bezieht sich auf innerfamiliäre erbrechtliche Auseinandersetzungen, welche dem Rat der Stadt Konstanz jeweils für einen strittigen Einzelfall zur richterlichen Entscheidung vorgelegt werden...”; Paul Baur, Testament und Bürgerschaft, 46 .

149 E.g. SCAB. 7, fol. 82-83 (1450); 86 (1450).

150 E.g. CONs. 428 , fol. 469 (1444).

151 "Die Merkelinne gap iren kindern ir erbe in einem voitdinge: pezolde vnde Thomas vnde Katherinen vnde Elsebeten, daz si alle glichen teil daran haben suln"; NKiRMK, no. 13.

152 "Petzcholdus von Rosenoue gab uf metzchen siner tochter den halben hof an des Borussen steynhuse, vnde darvber hundert march, vnde der ander tochyteren Elzben do bie den halben hof vnde hundert march, unde petere vnde hannus sinen Sunen dye hofe, do he inne voynnet, vnde ychlichem hundert march"; NKiRMK, no. 34. 
and mind - as the law required - transferred a home with a brewery to his wife Hedwig, giving her full right to dispose of it after his death. ${ }^{153}$ Similarly, Michael Grebe bequeathed half of the family manor house (curia) to his wife Elczka, noting that if she died first, the property would remain at his disposal. ${ }^{154}$ In a bequest from 1326 councillor Ulrich Tatar decided that in the event of his death, he would transfer to his wife Margaret his tenement building in Krakow, mines in Olkusz and all the other goods he owned in both of these cities. ${ }^{155}$ Those townspeople who did not have natural heirs (i.e. children) often donated part of their property to the Church. Such a bequest was made in 1320 by Herman Kopka, who bequeathed half of his house to his wife, and half to the church "for the salvation of his soul."156 In 1313, the butcher Ekel gave his wife his butcher's stall, which was to be sold after her death and the money used for religious purposes. ${ }^{157}$

In addition to the types of donations mentioned above, a new form of bequest appears in the book of the municipal bench court covering the years $1365^{-1376}$, the rapid proliferation of which may in some way be associated with the person of a notary named Nicholas and the operations of the municipal office. ${ }^{158}$ These are so-called 'mutual donations' (mutua donacio), in which a husband and wife agreed on the reciprocal inheritance of property in the event of the death of one of them. The first bequest of this kind concerned the wealthy matron (honoranda matrona) Merlina Czeslarinne, who soon after her

153 " [...] iure hereditario publice resignauit taliter, quod Curiam predictam cum braseatorio et omnibus aliis attinenciis vendere possit et donare, cuicunque persone voluerit Et facere et dimittere cum dicta hereditate Et Curia, quidcumque sue placuerit voluntati"; NKiRMK, no. 29o, 325, 455 .

154 "Item Michael dictus grebe medietatem Curie sue videlicet illam partem, que es contra portam Visle, et insuper XXX marcas Grossorum domine Elczce sue vxori resignauit, sed si ipsa prius eo morietur, tunc predicta ad ipsius redire debent potestatem"; NKiRMK, no. 430, 431 (1317).

155 "Item feria sexta iudicium fuit in vigilia beati Stanislai (26. Septembris), tunc vlricus Tartharus coniugi sue Domine margarete Curiam suam et domum lapideam in Cracouia et omnia bona sua tam in ipsa cracouia, quam in ylcus cum foueis sachtis et omnibus partibus iure hereditario cum fundo resignauit taliter et sic, quam diu ipse viuit, dicta bona omnia in sua debent esse potestate"; NKiRMK, no. 847 (1326).

156 "Item feria sexta post conductum Pasce (n. Aprilis) iudicium fuit, tunc Hermannus dictus Kopka medietatem Curie sue tocius vxori sue resignauit, reliquam vero medietatem ad Ecclesias et ad alia loca et ad pias causas pro salute anime ipsius assignauit"; NKiRMK, no. 589 .

157 Ekel then bequeathed half of his other slaughterhouse to his sister and her two children; NKiRMK, no. 284, 285 .

$15^{8}$ This notary was involved in producing the first part of the collection of town privileges and statutes, drafted around 1375; cf. Bożena Wyrozumska, Kancelaria, 118. 
marriage to Jacob Tendirnal donated to him her house on Sławkowska Street, while he, in turn, bequeathed it to her post mortem. ${ }^{159}$ Similar provisions soon began to be used in relation to all assets, as exemplified by an entry from 1371 in which Szczepan Oresnik bequeaths to his Virtuosa domina 'virtuous wife' Elizabeth and adult children all his movable and immovable goods, as well as six grivna to his not-yet-adult daughter (puero) Catherine as compensation. Elizabeth in turn bequeathed all these goods back to him in case she died before him. The contractual nature of this bequest is evidenced by an entry informing the reader of the issuance of two copies of this act. ${ }^{160}$ Soon a simple formula for 'mutual bequests' was developed, which included a phrase about the exclusion from inheritance of all other relatives and family members not mentioned in the bequest. ${ }^{161}$ These acts were a means of distributing goods and regulating their subsequent inheritance by a spouse (usually a wife), who after the disinheritance of other relatives, took possession of the entire estate. Some bequests briefly mention children, grandchildren or siblings to whom the spouse is to pass on a part of the property, ${ }^{162}$ and sometimes there is an obligation to do so when a couple eventually have children. ${ }^{163}$

In sources from Krakow from the first half of the fourteenth century, especially in the oldest surviving Krakow municipal book, ${ }^{164}$ the word 'tes-

159 "Honoranda matrona domina Merlina Czeslarinne, Peszcone de Sale pro tutore electo realiter et assumpto, presencialiter constituta domum suam ex opposito sancti Marci in platea Slaucoviensi fundamentaliter situatam Jacobo Tendirnal realiter et econverso dictus Jacobus domine Katherine uxori sue post mortem resignavit, interim tamen quoad vixerit wit illiusdem (esse) dominus atque heres"; SСAв., no. 15 (1365).

16o "Sczepan Oresnik omnia bona sua mobilia et immobilia, que habet vel fuerit habiturus, post mortem suam virtuose domine Elizabethconiuigi sue legitime et pueris suis resignavit, puero suo Katherine absolute VI mrc. Currentis monete eciam post mortem suam resignavit et econtra ipsa domina post ipsius mortem dicto suo marito omni modo, quo supra resignavit, et fiant due littere"; SCAB., no. 572.

161 E.g. "Nicolaus Gleywicz gladiator resignavit uxori sue omnia sua bona, exclusis omnibus amicis"; SCAB., no. 2227 (1396).

162 "Nicolaus Weydnow domine Margarethe conthorali sue in omnia bona sua hereditaria et mobilia equalem uni puerorum suorum post mortem suam tribuit porcionem, et si pueri morirentur, pars ipsorum ad dominam derivetur; si autem domina moriretur, extunc pars ipsius ad pueros devolvatur, exclusis omnibus amicis ipsius Nicolai"; SCAB., no. 2209 (1395).

163 "Niclos Jegirdorf et Dorothea ipsius Nico consors legitima, Johanne Czopchin sibi ibidem pro tutore recepto, omnia bona sua mobilia, hereditaria, que habent aut habituri fuerint, sibi invicem mutuo seu alterutrum, sub submissis condicionibus resignaverunt ita, si sine prole decederent, si autem pueros procrearent, tunc pueri consimilem porcionem debent habere et possidere, premissis non obstantibus"; SCAB., no. 1671 (1393).

164 This book contains entries from 1300 to 1375 , but in the 135 os the number of entries decreases significantly, to just a few entries per year; NKiRMK. 
tament' occurs just a few times, usually in reference to the fulfilment of the provisions of the will of the deceased. Nevertheless, among the other entries in the book there are a fairly wide variety of property ordinances. It is clear that for the burghers living in Krakow during this period, the term 'testament' meant a pious bequest ad pias causas - for the salvation of the soul. ${ }^{165}$ In this regard, the form used in the oldest preserved will, that made in 1303 by a Krakovian burgher woman named Sulisława, is characteristic. ${ }^{166}$ In both its form and content, it represents an excellent example of a canonical will. It begins with the invocation In nomine Domini Amen, followed by a formal legal statement about the health and soundness of mind of the testator and then her disposal of selected elements of her property, including a pious bequest for the rent from a butcher's stall and a bread stall to be donated to benefit Franciscan and Dominican monasteries and to fund the construction of the parish Church of St. Mary for salvation of her soul and the souls of her family members. ${ }^{167}$ In order to better secure these bequests, she appointed as executor of the will the Vogt of Krakow, Albert (who due to his public function had certain benefits granted to him and his family). To make the document itself "unquestionable and inviolable," the seals of both the Dominican convent, the guardian of the local Franciscans, and of the municipal councillors were secured to it. ${ }^{168}$

Sulisława's will is extremely valuable not only because of its early date, but also because it has been preserved in its original form. Although it is the only fully preserved burgher testament from the first half of the fourteenth century, it can be assumed that other wills drawn up by wealthy Krakovian burghers were probably similar in form, both before and after $1303 .{ }^{169}$ As has already

\footnotetext{
165 'The terms 'testament' and 'testamentum' as used in medieval sources have different meanings, in the general sense as dispositive documents, less frequently as ordinances of the last will, and more often as bases for the salvation of the soul"; Bogdan Bobowski, Kultura materialna, 20.

166 KDMK, vol. 3, no. 368, 493-494.

167 Bożena Wyrozumska, Kancelaria, 89-9o.

168 "Vt autem hec ordinacio firma et inmobilis perseueret, presentem literam sigillis Religiosorum virorum, videlicet prioris ordinis predicatorum, Guardiani ordinis minorum et honorabilium virorum ciuium cracouiensium feci roborari. Acta sunt hec in cracouia, Anno domini M.CCC. tercio, XIII kalendas Ianuarij"; KDM K, vol. 3, no. 368, 493-494.

169 "Die Geistlichkeit ist maßgeblich daran beteiligt, daß die Testamente auch in der Laienwelt Eingang finden. Die Vermächtnisse der Nichtgeistlichen lehnen sich in ihrer Form an die Klerikertestamente an. Wie diese sind sie im 13. Jahrhundert als Siegelurkunden ausgefertigt. Die Fülle der Testamentsurkunden von Kleriker- wie von Laienseite setzt mit dem Beginn des 14. Jahrhunderts ein. Während die frühesten mittelrheinischen Laientestamente die Form der Siegelurkunde aufweisen, wählen die Kölner Bürger, die erst seit 1300 testieren, zur Errichtung testamentarischer Verfügungen anfangs ausschließlich die
} 
been mentioned, the word 'testament' also appears in the oldest municipal book - albeit only nine times - each time in the context of bequests in opera pietatis. ${ }^{170}$ In one bequest from 1313 we read that the son of the Krakovian councillor Henry of Racibórz divided his estate and gave half of his movable and immovable property to his wife and brother-in-law, while he described his donation of five 'bread stalls' (i.e. stalls on which bread was sold) to a Krakow hospital as a bequest for the salvation of his soul. ${ }^{111} \mathrm{~A}$ will from 1321 includes a similar statement. Before going on a pilgrimage to Rome, Alusz, the widow of an alderman named Otton, made a last will before the court "for the salvation of her soul," in which she donated the significant sum of $3^{2}$ grivna to St. Mary's Church, St. Stanislaus at Wawel Church, and ad opus Ecclesie of the Dominicans, as well as to a hospital and her brother Nicholas, who worked in it. ${ }^{172}$

Form der Schreinseintragung, d. h. die Eintragung in die Bücher des Schöffenschreins. Das ist verständlich, wenn man bedenkt, daß die Schreinseintragung die seit über 150 Jahren gebräuchliche und daher geläufige Form für jede Art von Verfügung war. Erst allmählich gehen dann auch die Kölner Bürger zum Gebrauch der Siegelurkunde über"; Gabriele Schulz, "Testamente des späten Mittelalters aus dem Mittelrheingebiet, $5^{-6}$; Walter Hoffman, Deutsch und Latein im spätmittelalterlichen Köln. Zur äußeren Sprachgeschichte des Kölner Geschäftsschriftums im 14. Jahrhundert," Rheinsche Vierteljahrblätter 44, 1980, 146.

170 Henryk of Racibórz, NKiRMK, no. 286 (1313); Tymo the old, NKiRMK, no. 358 (1316); wife of Henryk Srolle, NKiRMK, no. 411 (1317); Wilhelm of Orient, NKiRMK, no. 477, 487 (1318); Alusza, widow of Otton, NKiRMK, no. 616 (1321); Konrad the brewer, NKiRMK, no. $75^{\circ}$ (1325); Hedwig (Heze) the stallholder, NKiRMK, no. 1537 (1344); Paszko the salt mine owner, NKiRMK, no. 1692, 1693 (1361); Arnold de Caucina, the nuncio and papal collector, a scholastic from Krakow, NKiRMK, no. 1707 (1375).

171 "Item in eodem iudicio contestato Henricus dictus de Rathibor suam medietatem bonorum omnium inmobilium tam in civitate Cracovia, quam extra civitatem suo sororio Henconi dicto Vinrich civi Cracoviensi dedit, assignavit et resignavit cum fundo iure hereditario possidendam, cum universes fructibus ac pertinenciis quod cum bonis eisdem facere ac dimittere debeat, quidquid sibi placet. Item idem Henricus medietatem suam bonorum omnium mobilium sue consorti domine Marusse in eodem iudicio contestato dedit, assignavit et iure proprietatis resignavit, quod cum bonis eisdem mobilibus facere et dimittere debeat, quidquid sibi placet.Item idem Henricus pro salute anime ipsius testamentum faciens, legavit quinque bancas panum ad hospitale in Cracovia"; NKiRMK, no. 286.

172 "Item domina Allussa relicta Ottonis quondam Ciuis Cracouiensis, dum Romam ad limina beatorum Petri et Pauli apostolorum pergeret, in predicto Iudicio prouinciali tale pro salute anime sue testamentum fecit: Legauit igitur ad Capellam beate marie Virginis in Ciuitate Cracouia pro fabrica Grossorum denariorum XX marcas, Item legauit ad opus Ecclesie beati Stanizlay in Castro Cracouie Grossorum denariorum quatuor marcas, Item Legauit ad opus Ecclesie ffratrum Predicatorum quatuor marcas, Item Legauit infirmis ad hospitale denariorum grossorum tres marcas et Ibidem ffratri Nycolao vnam marcam, Et omnes agros suos, quos habuit ante Ciuitatem Cracouiam cum vniuersis vtilitatibus ac 
The identification of religious bequests with wills is also clearly visible in an entry from 1344 by a stall-owner named Heze. In it she obliges one of her daughters to pay 20 grivna "for testament" in return for the house she has received as her dowry, a requirement that should most certainly be understood as a pious bequest for the mother's soul. ${ }^{173}$ Similarly, in other entries concerning the fulfilment of the wills of Krakovian burghers, the term 'testament' always indicates a bequest to a religious institution. ${ }^{174}$ The majority of such acts, as in the case of Sulisława's will, which was stored in the archives of the Franciscan monks in Krakow, ${ }^{175}$ were written down in the form of a document, in the presence of representatives of the churches and monasteries who authenticated them with their seals and gave the church's sanction to the decisions contained in them. Both the negligible number of such surviving wills, and negligible references to them in municipal books before the 139os, as well as the custom of describing with the word 'testament' acts containing pious bequests for the salvation of the soul, suggest that other bequests of last will from that time which have not been preserved were most often made in accordance with the principles of canon law and were only occasionally additionally certified before the municipal court. ${ }^{176}$

prouentibus, Hanconi filio sue sororis in predicto resignauit Iudicio, Quod si reuersa non fuerit, quod extunc infra quatuor annos soluere debeat dictum testamentum de bonis adque agris predictis ad loca prescripta et ad Ecclesias memoratas"; NKiRMK, no. 616.

173 "Eodem Anno diuisio hereditatum et bonorum inter pueros Heze Institricis sane mentis facta erat, ita quod Katherine filie eiusdem cessit domus, que est sita contra predicatores, pro sua sorte taliter, quod eadem Vnica XX marcas grossorum daredebet pro testamento de eadem domo. Insuper dicta Katherina cum Marito et pueris eiusdem coram Consulibus et Iudicio Bannito abrenunciauit omni iuri, quod in alijs hereditatibus, rebus mobilibus habere possent, ita quod Salmiam Sororem eius et pueros Thome fratris eiusdem in hereditatibus et rebus mobilibus decetero nunquam inpetere debeat verbo penitus neque facto, sed ab eadem Katherina ab omni inpeticione liberi esse debent in antea et exempti in perpetuum"; NKiRMK, no. 1537.

174 For example, Marusza, the widow of alderman Wilhelm of Orient, said before the municipal bench court that her husband had made a will where he provided that one grivna of the annual rent for half of his manor house at Shoemaker's Street was to be donated to St. Mary's Church to fund candles, for the salvation of his soul; NKiRMK, no. 477, 487 (1318).

175 The Archive of the Province of the Franciscan Order in Krakow, ms G-I-2; cf. Dariusz Karczewski, "Miejsce krakowskiego klasztoru franciszkanów w strukturze czesko-polskiej prowincji zakonnej," in Mendykanci w średniowiecznym Krakowie, ed. Krzysztof Ożóg, Tomasz Gałuszka, Anna Zajchowska (Krakow: Esprit, 2008), 89.

176 This practice is evidenced indirectly by an entry in the Głogów municipal book from around 1386, according to which a person lying 'on their deathbed' could decide for himself whether to make a pious bequest before a priest or a secular court.: 'Der an sich 
The first known testament from Krakow, made from the testator's death bed, was that of Paulino Cavallo (also known as Paszek), a Genoese-born councillor in Krakow and administrator of the Bochnia salt mines (1344-1358). ${ }^{177}$ His bequest was the first - and for some time the only - evidence of the later practice of deathbed wills being drawn up in the presence of two or three councillors called as witnesses. ${ }^{178}$ The councillors, perhaps being aware of the uniqueness of the situation, gave a detailed account of the circumstances in which it occurred: "Councillor Paszek, being in ill health, requested that two councillors come to him immediately, God willing, before whom he could make his last will and testament. And two councillors came to him, Peter Winryk and Nicholas Edeling, and witnessed his last will and testament, written and sworn by Paszek on his oath and faith." 179 Afterwards the councillors recorded the full text of the will "made in the moment of his death," in which Cavallo distributed part of his possessions, making generous bequests to his relatives and servants, and to clergy members, a hospital, and churches in Krakow. The religious character of this will is indicated by, among other things, the fact that there is no mention in these bequests of any of the properties he possessed, which would have been due to the deceased's wife and children. This omission suggests we may consider this will as a kind of 'canonical will,' made already in the presence of city authorities and not representatives of the Church, what was against the canon law.

The few mentions of testaments from the latter half of the fourteenth century up until the early 1390 continue to show that the testament was understood as a pious bequest made by a healthy man or woman in the municipal court or before clergy from the churches and monasteries that were to receive

bette todlich zelgerethe mag doz billichvorgangk in geystlichim rechte oder in wertlichim rechte'; za: Karol Koranyi, Podstawy średniowiecznego prawa spadkowego, 115.

177 Józef Piotrowicz, "Żupy krakowskie w pierwszych wiekach rozwoju, od połowy XIII do połowy XVI wieku," in Dzieje żup krakowskich, eds. Antoni Jodłowski et al. (Wieliczka: Muzeum Żup Krakowskich Wieliczka, 1988), 118; Marcin Starzyński, Krakowska rada, 233.

178 It can be assumed that the testator, who came from outside Krakow, played a significant role in this case.

179 "Pasco Zupparius protunc Consul rogauit instanter, ut dei intuitu duo de Consulibus ad ipsum venirent, qui interessent suo testamento et sue vltime voluntati, quod facere vellet in eadem infirmitate, Et constitutis apud eundem Pasconem duobus Consulibus, videlicet Petro Winrici et Nicolao Edlingi talem suam vltimam voluntatem et testamentum conscriptam et factam per ipsum Pasconem sub Iuramento et fide protulerunt et ordinarie conscriptam pronunciauerunt, ut subsequitur in hec verba"; NKiRMK, 1692 (1358). 
the bequest. ${ }^{180}$ Apart from just one disposition, ${ }^{181}$ the other mentions of testaments merely concern the fulfilment of their provisions, ${ }^{182}$ or disputes arising from them. ${ }^{183}$ A dispute between the three daughters of the late councillor Alex of Racibórz provides an indirect example of this practice. ${ }^{184}$ The daughters were not only to divide up the large estate left by their father, carry out renovations on the family house, and distribute the items contained within it, but also collectively to fulfil the dispositions left by him in his will. As can be deduced from the content of these bequests, he ordered the repayment of a debt of 20 grivna he owed to his deceased sister, and bequeathed 75 grivna to establish an annuity payment for a chapel in St. Mary's Church. ${ }^{185}$

Another will, dated 1393, states explicitly that it was drawn up by an ailing man in the presence of Krakow municipal councillors, who had been called to him. This was the bequest of last will made by Gottfrid Fattinante, an administrator of the salt mines in Bochnia and Wieliczka, who, like Cavallo, came from distant Genoa. ${ }^{186}$ At the beginning of the testamentary bequest,

180 The existence of this form of the will is indicated by a entry in the books of the Krakow municipal bench court from 1392 that mention Elena and Masza's claim to the household equipment and personal belongings (omnia supellectilia rade dicta) of their deceased sister Catherine (Czenke Katusze). However, their lawsuit was dismissed and the goods remained in the hands of Martin, the parish priest of Bodzanów, the executor of the deceased's will, who was to settle her debts and allocate the remainder of her estate to opera pietatis; SСАВ., no. 1482 (1392).

181 There is a mention of seven grivna left in the 'trusted hands' (ad manus fideles) of Margaret Crenczlarinne by Margaret, 'mother-in-law of Nicholas Wronche,' who was about to embark on a pilgrimage to Rome, and in the event of her death, her son and daughter were to receive three grivna each, while one grivna was to be donated for the salvation of her soul; SCAB., no. 218 (1367).

182 SCAB., no. 933 (1374), 937 (1374), 1064 (1375), 1109 (1375), 1445 (1392), 1546 (1392).

183 SCAB., no. 1122 (1375), 1243 (1376), 1309-1311 (1391), 1502 (1392).

184 The fact that the testator Allexius was in fact the Krakow councillor Alex of Racibórz is indicated both by the years he held this function (1375 and 1379), the enormous estate listed in his will, including the tenement building at the Krakow old market square, and the fact that his sister Margaret was married to the wealthy Krakow councilor John Dobschicz, whose will was registered in the books of the municipal bench court; SCAB., no. 1309-1311 (1391), 2093 (1395).

185 "Item Hildebrandus notarius civitatis et Mathias Arnsberg presencialiter constituti recognoverunt publice, quomodo pueri seu filie condam Alexii videlicet A[gnes], B[arbara], illas quinquaginta marc, quas dictus olym Allexius in suo testamento pro capella ad beatam Virginem pro censu assignavit, in tribus partibus suis domus acialis eiusdem condam Allexii earum patris tenentur"; SCAB., no. 1311 (1391).

186 He came to Krakow from Genoese Kaffa on the Black Sea, where part of his family settled; cf. Józef Garbacik, Gotfryd Fattinante, in PSB, vol. 6 (Krakow: Wrocław-Warszawa-Krakow: Polska Akademia Nauk, Polska Akademia Umiejętności. 1948), 377-378. 
three councillors and a municipal notary testify that they had come to Gottfrid at his special request to bear witness to his last will. ${ }^{187}$ After making a number of bequests, Gottfrid chose as the executors of his last will (variously, in Latin, procuratores, factores, actores et executores legitimos atque certos) a doctor of Canon and Roman laws, Bishop of Krakow Peter Wysz of Radolin, Voivode $^{188}$ and Starost ${ }^{189}$ of Krakow Spytek of Melszin, as well as "all present and future" Krakow municipal councillors. The will ended with an invocation by the councillors asking God to support them with his divine justice and mercy and noting that they had affixed the city seal to authenticate the document. ${ }^{190}$ In this way they verified all the bequests contained in this document, which covered all of Gottfrid's assets. The councillors referred to an unspecified Krakow privilege to legitimize their actions - "written privilege of the city" (literarum Ciuitatis priuilegiarum). ${ }^{191}$ This will was accepted by the councillors

187 "Nos Consules Ciuitatis Cracouiensis recognoscimus, quibus expedit, vniuersis, quod coram nobis, dum ad certum congregati fuissemus consilium, prouidi Nicolaus Bothmer, Nicolaus Sapnig et Nicolaus Dambrow nostri consortes consilij, necnon Petrus nostre Ciuitatis predicte Notarius, fideles et dilecti presencialiter constituti, sub fide et iuramento ipsorum infrascripta recognouerunt, pronunciauerunt et vniformiter protulerunt publice et expresse, quod cum auctoritate ofiicij consulatus nostri Famosum virum dominum Gottfridum Fattinantem de lanua nostrum conciuem ex sua vocacione et rogacione speciali, vt sue voluntatis vltime disposicioni attendentes accessissent, idem Gottfridus licet debilis aliqualiter corpore, multa tarnen bona perfluens racione, voluntatem suam vltimam perpetuo duraturam, testando ac perpetuo et libere legando expressit atque constituit in hunc modum. Idem Gottfridus licet debilis aliqualiter corpore, multa tarnen bona perfluens racione, voluntatem suam vltimam perpetuo duraturam, testando ac perpetuo et libere legando expressit atque constituit in hunc modum"; KDWac., vol. 2, no. 396, 182-185 (1393).

188 See Glossary: Voivode

189 See Glossary: Starost

190 An entry from 1393 concerns the execution of this will by Sułek, who acted as a bishop's prosecutor, and the voivode and castellan of Krakow Spytko of Melsztyn. Further mentions of its execution in 1397 and 1398 can be found in the council book; SCAB., no. 1720; Cons. 427, fol. 166 .

191 "Propter quod prefatus Gottfridus, prout predictorum presentis testamenti pronunciatorum relacione didicimus, nobis supplicauit pure ac humiliter propter Deum, quatenus diuine iusticie et misericordie intuitu presens suum testamentum ad maioris certitudinis euidenciam nostre ciuitatis authentico, sub quo omnia ratificata et confirmata et presertim legata et testata inconvulse secundum tenorem literarum Ciuitatis priuilegiarium perseuerent, ratificare, approbare et confirmare benignius dignaremur. Nos vero diligenter ac maturo inter nos tractato consilio, considerantes peticionem suam presentem fore iustam et honestam, angelis gratam, atque rem ipsam, pro qua petitur, ad laudem et honorem summi et omnipotentis Dei matrisque eius benedicte ac sanctorum Anthonij et Dorothee, de quibus supra, gloriosius pertinentem, perpendentesque nihilominus vniuersa omnia et singula suprascripta per premissum Gottfridum racionabiliter fore facta, 
for "the greater glory of God, His Mother and Saints Anthony and Dorothy"; it was also approved by the Bishop and Voivode, and was stamped with the city seal. It was thus fully secured against any attempt to overturn its provisions. This will testifies both to the expansion of burghers' rights to distribute their property, and to a new practice among wealthy Krakow burghers of making wills on their deathbeds in the presence of municipal councillors. From this point onward, the municipal council would increasingly encroach onto the competences of priests, who, in accordance with canon law, were at that time responsible for the protection of wills. It can be assumed that in the 139 os wills in Krakow lost their former religious character and changed from the 'canonical will' into something that can be described as a 'communal will.' It seems not to have been a coincidence either that the first two known wills drawn up by infirm individuals in the presence of municipal councillors belonged to influential mining officials (zupnicy) who had come to Krakow from Genoa. Although we know of no other wills from that period, it seems valid to hypothesize that wealthy Italians had a major influence on the evolution of testamentary practices in Krakow. The end of the fourteenth century was also in general a period of rapid change in the culture, economy and society of Krakow. It was a time of dynamic economic development in the city, and rapid influx of immigrants, the widening participation of burghers in written culture, and the growing influence of the Krakow municipal council, which was gradually trying to expand its jurisdiction over church institutions functioning within the walls of the city and the religious life of its inhabitants. ${ }^{192}$

Emergence of the Communal Will in Krakow

The number of wills and testamentary dispositions from the early 1390 preserved in municipal books is roughly equal to the number from the previous nine decades. In part, this rise in the number of bequests can be explained by the state of the sources themselves. ${ }^{193}$ Nevertheless, we can also speak about a

disposita, testata, legata ac deifice ordinata, eadem in omnibus suis punetis, clausulis et distinccionibus approbamus, ratificamus et sigilli dicte ciuitatis appensione perpetuo confirmamus"; KDWac., vol. 2, no. 396 (1393).

Jerzy Wyrozumski, Dzieje Krakowa, 314-391; Agnieszka Bartoszewicz, Piśmienność, 70, 146-147; Halina Manikowska, "Religijność miejska," in Ecclesia et civitas. Kościót i życie religijne w mieście średniowiecznym, eds. Halina Manikowska, Hanna Zaremska (Warszawa: Instytut Historii PAN, 2002), 29-30; Marcin Starzyński, Krakowska rada, 116-132.

193 Contributing greatly most to this situation was the fact that the book of the municipal bench court from the years 1376-1391 did not survive to the present day. 
qualitative change in the form and function of wills in the late fourteenth century. ${ }^{194}$ In 1393 , the complete texts of wills began to be recorded in the municipal books (initially in the books of municipal bench courts), and we can see from these records how their content was changing. ${ }^{195}$ There was a noticeable reduction in pious bequests, which gave way to dispositions concerning the distribution of property between close relatives, such as those safeguarding the rights of widows and children, and those regulating the rules of inheritance by children from first and second marriages. These and other secular motivations are more visible in fifteenth-century wills. This does not mean that pious bequests for the salvation of the testator's soul disappeared from the bequests. They remained a permanent element of many, but seemed to play only a minor role in them. For example, in that same year (1393), it was decided in the will of the alderman and later councillor John Ederer that his first wife, if she remained a widow and managed the remaining property well, could dispose of it up until the end of her life. ${ }^{196}$ However, if she was unable to manage the estate, care for it was to be taken over by guardians specially chosen for this task. Next, the testator, probably seeking to avoid family disputes, ordered that his son would assume control of his part of the estate only after the age of 24 , and that his widow, if she re-married, would receive a dower ${ }^{197}$ of 15 o grivna. In the event that his son died before reaching the age of maturity, the part of the estate set aside for him was to be used to make pious gifts of 20 grivna for the construction of Mogiła Abbey's cloister and ten grivna for the construction of the Church of St. Mary. John's brother, in turn, was to receive 40 grivna, while the remainder of the estate would be distributed to support charity work at the discretion and will of the executors. ${ }^{198}$ The purpose of this will seems for

194 "In the late fourteenth century, separate accounting books were created from general council books; it is likely that at that time village adminstrators began keeping their own records. The need to keep records of privileges and announced judgements motivated the production of collections of copied documents. In the early fifteenth century, a separate section for additions to municipal law was also created from council books, and a little later, wills began to be entered into a separate manuscript [rather earlier - B.W.]. The municipal administration grew along with the development of the city and the expansion of the agendas of the local government, which was taking on an increasing number of responsibilities."; Bożena Wyrozumska, Kancelaria, 127.

195 The first of these belonged to Nicholas Strelicz, an alderman who later became a councillor; SCAB., no. 1645 .

196 Józef Mitkowski, Jan Ederer, in PsB, vol. 6 (Krakow: Wrocław-Warszawa-Krakow: Polska Akademia Nauk, Polska Akademia Umiejętności, 1948), 201-202.

197 See Glossary: Dower

198 "Johannes Oderer antworte eyn czedilpapir, dorin her syn testament vnd lecztin willin yn geschrebin hatte, daz noch wortin luth alsus: ab mich got czu synem gnadin neme 
the most part not to have been saving the testator's soul, but rather providing economic security for his loved ones. The majority of other wills in the 139os and in the following decades were similar in this respect.

We also learn from the municipal books that these acts were now being recorded in a new way. In them 39 wills have survived from the seven-year period between 1393 and 1400. Fifteen of them state that they were copied into the municipal books after having been originally written down on sheets of paper (cedula papirea) brought to the municipal authorities by the testators or executors of the wills. Moreover, in five cases the original notes (notule) have survived, ${ }^{199}$ having been pasted between the pages of a book of the municipal bench court. ${ }^{200}$ These surviving loose sheets make it possible to compare the original contents with the entries made in the book. An analysis of them shows the municipal notary modified very little when he recorded them in the municipal book, his interventions typically being limited to a short Latin, or German, ${ }^{201}$ introductory sentence providing information about the testator,

vnd mein weip yn erem wittwenstule blebe siczczin, so sal sy mynes guttis eyne vrawe bleybin mit sampt mynem kinde bis an ir ende, alzo daz sy rechenunge tue alle jar den vormunden von dem gutte; is das sy das gut bessert, so sullin is ir dy vormunde lossin, wo sy ys nicht enbessirte, so sullen is dy vormunden nemen czu en vnde sullen de mete des bestin nemen vnd sullin muttir vnd kinde ere notdorf douon gebin; ab myn zon gewuchse vnd sein teile des guttis welde habin, dem sal man nichtis gebin, her kome denn czu XXIIII jaren; ab myn weip eren witwinstul vorruckitte, so sal man ir gebin vor morgingobe vnd vor allis, das sy angesterbin mochte von mynes kindes wegin, andirhalp hundert mrc. breitir groschin, vnd ab vnser hirre mynen zon czu synen gnodin neme, was da guttis bleibt, das sullin dy vormunde gebin, XX mrc. czur Mogil czum gewelbe des crucegangis, vnd ab dy vormunde sehen, das sich myn brudir Sigemunt welde neren vnd sich wol anlisse, so sullin em dy vormunde gebin XL mrc. gr. breitir, vnd czum gewelbe vnsir Vrawin bescheide ich X mrc. gr., waz dorebir blebe, das sullen sy gebin czu stege vnd czu wege vnd armen luthen douon [...] vnd sy kleiden douon vnd [...] der barmherczigkeit douon czu tun, doczu kyse ich Rudolfum vnd Petrum Brigir desir dinge czu vormunde, ab ir eyner abginge, das der eyne eynen andirn kyse, als erste, als sich das geborit, vnd dy hirschaft dirre gobin behalde ich mir, dy weile ich lebe"; sCAв., no. 1676 .

The will of councillor Nicholas Dambraw includes the following note describing this kind of testamentary provision: "Nota quod Hermanno zuppario data est una littera notule prescripte, item domine Dambrynne data est una littera"; SCAB., no. 2210 (1395).

200 SCAB. 3, fol. 106a, 106b, 106c (1393); 140a, 140b (1394); 168a, 168b (1395); 188a, 188b, 188c (1395); cf. Agnieszka Bartoszewicz, "Języki wernakularne w testamentach mieszczan krakowskich XIV-XV w.", кн км, 61, No 2 (2013), 251-261.

201 E.g. "Stano Mochaw presentavit cedulam papiream ad iudicium sub hac form"; sCAB., no. 1654 (1393) or "Martinus Junge presencialiter constitutus, sanus corpore, compos racionis, testamentum suum seu ultimam ipsius voluntatem in quandam cedulam ydeomate teuthonico conscriptam, presentavit, cuius tenor sequitur et est talis"; SCAB., no. 1816 (1393); 
his mental and physical health, ${ }^{202}$ and his right to dispose of the property. ${ }^{203}$ This was followed by an accurate transcription of the contents of the notula, usually written in the first person, and occasionally in the third person. ${ }^{204}$ The slight differences found are generally limited to misspellings. Some wills from the fifteenth century note that they were transcribed from sheets of paper brought before the court, but in these cases the original notule themselves have not survived. ${ }^{205}$

In contrast to earlier periods, a significant number of these entries (20) were made in German - the mother tongue of many Krakovian burghers. ${ }^{206}$ This change reflects the influence of making literal transcriptions of notule into municipal books and of the anonymous figure of the municipal notary who produced them. It is interesting that in at least one case - that of councillor Nicholas Dambraw - the will was written by the testator himself. ${ }^{207}$ Nevertheless, the form and content of the dispositions made in it do not differ substantially from other extant wills from that period.

This sudden popularization of wills (or perhaps only of the practice of entering them into municipal books) may have been related to two successive major jubilee celebrations in Rome in 1390 and $1400 .^{208}$ The desire to participate in these massive ceremonies, fed by the indulgences promised by

"Johannes Ederer antworte eyn czedilpapir, dorin her syn testament vnd lecztin willin yn geschrebin hatte, daz noch wortin luth alsus"; sCAB., no. 1676 (1393).

"Martinus Junge presencialiter constitutus, sanus corpore, compos racionis, testamentum suum seu ultimam ipsius voluntatem in quandam cedulam ydeomate teuthonico conscriptam, presentavit, cuius tenor sequitur et est talis"; SCAB., no. 1816 (1393).

203 "Utrum cum singulis suis bonis elaboratis et ceteris possit facere et dimittere iuxta libitum voluntatis et est ita sentenciatum"; SCAB., no. 1645 (1393).

204 Eg. the will of Hanco Czartke; SCAB., no. 2069 (1395).

205 Eg. the will of Dorothy, wife of Stanisław Homan, SCAB. 4, fol. 71 (1412); Nicholas Morsztyn, SCAB. 4, fol. 143 (1416); Peter Putko, SCAB. 6, fol. 158 (1438); Peter Warzigarnek, SCAB. 7, fol. 100 (1450); Ursula, the widow of Eustace, a municipal notary "edidit ultimam voluntatem et testamentum suum tali modo ut sequitur ex scedula sua convocata in almanico wulgari scripta," LT, fol. 148-149 (1489) and many others.

206 SCAB., no. 1641 (1393), 1654 (1393), 1676 (1393), 1755 (1393), 1773 (1393), 1774 (1393), 1816 (1393), 1894 (1394), 1931 (1394), 2041 (1394), 2042 (1394), 2069 (1395), 2070 (1395), 2093 (1395), 2210 (1395), 2354 (1396); CONS. 427, fol. 149 (1400), 151 (1400), 152 (1400), 157 (1400).

207 "Nicolaus Dambraw testamentum suum in carta papirea manu sua propria ydeomate theutonico conscriptum presentavit, cuius tenor sequitur in hec verba"; SCAB., no. 2210 (1395). A piece of paper glued between the pages of the book containing the will and testament of this councillor has also been preserved, and, as indicated above, was handwritten by him; SCAB. 3, fol. 188a, 188b (1395).

208 Halina Manikowska, Jerozolima - Rzym - Compostela. Wielkie pielgrzymowanie u schytku średniowiecza (Wrocław: Wydawnictwo Uniwersytetu Wrocławskiego, 20o8), 7. 
the papacy and encouragement from the Church to express religious zeal in this way, prompted some of Krakow's inhabitants to embark on a pilgrimage to Rome. We find traces of this decision in several wills from that time. In 1396, municipal councillors in Krakow established the first book of wills, which unfortunately has not survived to the present day. This year can be regarded as the point when the changing attitude towards these acts was formalised. This was also most likely when the municipal council introduced as a permanent custom the visits of councillors to ailing burghers in order to witness their last will. This was connected, firstly, with the assumption of powers previously exercised exclusively by the clergy, and secondly, with the recognition by the municipal authorities of the form of the will made in "the moment of death" (in articulo mortis), which was contrary to a municipal law prohibiting donations to be made by those suffering from illness. Wills written in the presence of councillors had numerous canonical features, i.e. they could be made only in the presence of three witnesses - a mayor and two councillors - by people already on their deathbed; in most cases their content was clearly secular, even when they contained pious bequests.

This newly created book of wills was referred to as 'Book of Wills and Dowers' (Liber Testamentorum et Dotaliciorum) in the accounts of the municipal expenditures for that year. ${ }^{209}$ The fact that it was written and maintained by municipal notaries until at least 1410 is known from a short note that precedes Bartek Hofer's will, published in the Krakow council book that year. ${ }^{210}$ Its later fate and the number and nature of entries it contained are unknown, but we can nevertheless draw some conclusions about its content from its title, The Book of Wills and Dowers. The title indicates a seemingly inexplicable link between such two very different acts as the provisions of a will and bequests of a dower due to a wife in accordance with the marriage contract concluded by spouses.

The explanation of this connection may be found in the content of the survived wills from that period. At the turn of the fifteenth century, almost all

209 Expenditures for 1396 on Pretorij necessaria included two entries: "Item pro pergameno comparato ad libros testamentorum et dotaliciorum II mrc. XVI $1 \frac{2}{2}$ gr. Pragen" and "Item pro ligacione librorum testamenti et dotaliciorum I mrc"; "Registra perceptorum et distributorum civitatis Cracoviensis annorum 1390-1393, 1395-1405 nec non 1407-1410," ed. Franciszek Piekosiński, in Libri antiquissimi civitatis Cracoviae saeculi decimi quinti, pars posteriori (Krakow: Akademia Umiejętności, 1877), 313.

210 "Testamentum Bartken Hofer - Wir Johannes Borg, Petir Vochsczagil, Hartlib von Cluczke," and in other handwritting - "vide in libro testamentorum"; cons. 427, fol. 371; Bożena Wyrozumska, Kancelaria, 92. 
wills contained provisions confirming and guaranteeing the fulfilment of the obligations contained in marriage contracts. These provisions included, above all, confirmation of the amount of the dower promised to the wife and the rules for the distribution of property between the spouses (and their descendants) in the event of either of their deaths. At the end of the fourteenth century, Krakow's municipal books contain testimonies suggesting that at least some of the wills were made shortly after a first or second marriage. ${ }^{211}$ The reason for their creation and authentication by the court seems to have been primarily the need to legally regulate the new properties and changed social situations of all the interested parties. This is evidenced both by the structure of the bequests, which often begin with a detailed description of the situation of one spouse in the event of the death of the other, a designation of his or her part of the estate and the rules for inheritance, followed by the instructions on how to proceed if children are born from the marriage. In his will the Krakow alderman and later municipal councillor Nicolaus Strelicz bequeathed his entire estate to his wife; however, he also stipulated that if children were born, she would be given a rich dower and a part of the estate equal to that received by the children. ${ }^{212}$ Peter Puczk did the same, specifying the amount his wife had brought into the marriage, but also stipulating that the sum she was to receive after his death would be reduced if they were to have children. ${ }^{213}$ In some wills, it was expressed explicitly that the bequest was being made to safeguard the rights of the testator's second wife and the distribution of property between her, their future children, and the children from the first marriage. ${ }^{214}$

The husband's responsibility for his wife as the administrator of their shared property meant that the most important part of the marriage contract was determining the size of the dower to which the woman was entitled after her husband's death. Originally performed orally in the presence of witnesses, this act later assumed a written form, reflecting the expansion both of the

211 Brigitte Klosterberg also notes these similarities, see: eadem, Zur Ehre, 207; for a more detailed discussion of the subject see Jakub Wysmułek, "Wills as Testimony of Marriage Contracts in Late Medieval Krakow," in Law and Marriage in Medieval and Early Modern Times, Proceedings of the Eight Carlsberg Academy Conference on Medieval Legal History 2011, eds. Per Andersen, Kirsi Salonen, Helle Møller Sigh, Helle Vogt (Copenhagen: DJøF Publishing, 2012), 181-19o.

212 SCAB., no. 1645; cf. Jacek Laberschek, "Mikołaj Strzelicz," in PSB, vol. 45 (Warszawa-Krakow: Polska Akademia Nauk, Polska Akademia Umiejętności, 2007), 16-17.

213 "[...] ab ich sturbe ane fruchte [...] adir ap uns got fruchte gibt mitenandir"; SCAB., no. 2354.

214 E.g. the wills of Martin Junge, SСAв., no. 1816 (1393) and John Michilwicz, SCAв., no. 2070 (1395). 
municipal bureaucracy and the municipal authorities' powers. ${ }^{215}$ These developments are reflected in the resolutions of municipal councillors. For example, municipal statutes on weddings from the latter half of the fourteenth century (1378 and 1397) state that "if a man gives his wife a morning gift [morgengabe], he should come four days earlier to the councillors with his fiancée, relatives or alone and have the gift recorded so that in the future what was intended would come to be, and there would be no disputes among the relatives." ${ }^{216} \mathrm{~A}$ later Krakow municipal statute from 1468 renewing "city resolutions compiled from earlier sources," extended this period to eight days after the wedding day. ${ }^{217}$ Although there are references in Krakow's municipal books to dowers as early as the early fourteenth century, and the first entry containing a bequest calling for a dower to be paid from the husband's estate dates back to 1338, this type of entry was extremely rare. Nevertheless, in the late fourteenth century we can observe an interesting phenomenon in the records of the municipal offices, as bequests for the payment of dowers began to be associated with the idea of the 'testament.' Starting around this time, information about the size of the dower and the rules for dividing the estate among the heirs became fixed elements of late medieval wills. A characteristic example of this is the will of the Krakovian patrician John Bozemecz, whose last will states merely that his wife was to receive one third of his estate as a dower after his death. ${ }^{218}$ An analogous bequest was made by the tailor Dinek, who bequeathed one third of his house to his wife Elisabeth (in the presence of his sisters and Elisabeth's legal guardian). ${ }^{219}$ Other wills from this period also deal primarily with the size of the dower and the regulation of the distribution of property after the death of the husband. They do not contain any pious bequests, nor were any written down on the testator's death bed.

215 Richard H. Helmholz, Marriage Contracts in Medieval England, in To Have and to Hold. Marrying and Its Documentation in Western Christendom, 400-1600, eds. Philip L. Reynolds, John Witte (Cambridge: Cambridge University Press, 2007), 260-286.

216 Najstarszy zbiór przywilejów i wilkierzy miasta Krakowa, vol. 2, ed. Stanisław Estreicher (Krakow: Polska Akademia Umiejętności, 1936), no. 15.

217 KDMK, vol. 2, no. 334.

218 "Johannes Bozemecz testamentum suum condidit in hunc modum, ita videlicet, quod domina sua Agnes pro dotalicio et omnibus aliis terciam partem in omnia ipsius bona hereditaria et mobilia habere debet post mortem suam et tenere, reservat etc."; sCAB., no. 1914 (1394).

219 "Dinko sartor terciam partem domus sue in plathea sancti Floriani circa domum Jlkusserinne, presentibus Katherina, Agnete et Margareta filiabus suis et pro Nicolao Wislicia consencientibus, pro dotalicio et omnibus aliis ipsam concernere valentibus Elyzabeth conthorali sue resignavit; reservat dominium"; sCAB., no. 2278 (1396). 
In the light of the observations above, we can conclude that there are clear similarities between 'testaments' written in the late fourteenth century and both acts concerning donations to be made "in the event of death," records of dowers, and mutual bequests drawn up in the fourteenth and fifteenth centuries by Krakovian burghers. As the concept of the will took shape during this period, it came to include a variety of previously separate and independent donations and bequests, which now assumed a new, unified form. An example of the typical form in which a burgher's will was recorded in a late-fourteenth century municipal book is the entry for John Michilwicz's last will from 1395, which contains, according to my own classification:

1. The circumstances in which the will was written. The first sentence (in Latin) states that the document was written on a sheet of paper in German.

This is followed by the text of the will, written in the first person:

2. Provisions of the dower. Information about the amount of money that should be given to his wife and about the movables (gerada) that belong to her.

3. Donations outside the equal division of the estate. There is a donation of 30 grivna to a daughter from a previous marriage, to be made from the property allocated for division.

4. Principles for the division of property between children: "if God will give him [further] children with this or another wife, if there will be one," the remaining goods will be divided equally among any new children and the previously-mentioned daughter. However, if no further children are born, then this daughter will inherit everything.

5. Protection of the power of the executors of the will over the children. If one or more children do not heed the chosen executors (vormunden), the latter have the right to disinherit them and spend their share of the assets on pious bequests.

6. A donation in opera pietatis. If the testator survives his children, the executors of the will shall be entitled to sell his inherited property and other goods, and to distribute the money received among the poor according to their wishes.

7. Designation of executors. The appointment of four executors, indicating that if one of them dies, "as often happens," the others have the right to choose another in his place. ${ }^{220}$

220 This classification is based on the present author's own research and observations. Although there are numerous exceptions to this classification due to the great variety of such acts, it reflects the new nature of testamentary provisions in the late fourteenth cen- 
This formula, like that found in many other wills, consisted of seven individual bequests, most of which could also be made in the form of a declaration of last will or a traditional donation. Such instructions, which were sometimes referred to (but not always) as wills, were also combined with 'mutual bequests.' An example of securing a dower with a mutual donation is a bequest of 30 grivna made by John Steynbach on behalf of his wife Clare, who also bequeathed to her husband all of her goods. ${ }^{221}$ Mutual bequests were also combined with bequests in opera pietatis, such as that made by Hensil Clingner and his wife Elisabeth, who bequeathed all their goods to each other in the event of the death of one of them, noting that if both of them and all their children died, their property should be transferred to the Church. ${ }^{222}$ There are also more extensive mutual bequests concerning the provisions for the

tury: "Johannes Michilwicz testamentum suum in cedula papirea conscriptum ydeomate teutonico presentavit, cuius dispositio testamenti sequitur in hec verba: Ich bekenne das ich Katherin meyner elichin husfrawen gemorgengobt habe XXX mrg., dy sal se nemen noch meynem tode von meyner varnden habe, dorczu ir gerade, dy ir mit rechte geboren mag, also verre, als se, mich obirlebt, auch gebe ich Margarethen meyner tochter, dy ich vor gewinnen habe mit meyner ersten frawen Dorothea genant, XXX mrc. groschin in meyn gut erbe vnde varnde czuvor vs czu hebin vor allir teylunge, doch also, wurde mir got kinder geben mit desen frawen adir mit andirn, ap ich dy haben wurde, das dy czukunftigen kinder mit der vorgenanten Margriten myn guth vnd meyn erbe czu gleichim teile nemen sullen, vs genomen dy XXX mrg. dy Margaretha czuvor vs hebin sal, auch also, ap das got fugen wurde, das ich abeginge vnde nicht me kinder lisse, wenne dy vorgenannte Margarite, so sal dy selbe Margaretha meyn erbe vnd meyn gut, das ich lossen wurde noch meynem tode, gancz vnde gar hebin vnd nemen, vsgenomen dy vorgeschreben XXX mrg., dy ich Katherinen meyner husfrawen gemorge(n)gobt habe, doch das mit namen doryn genomen, was ich kinder wurde lossen noch meynem tode, ap der eyns adir me desen nochseschreben vormunden nicht gehorsam wurde seyn, das dy selbin Vormunden irkenten, das meyn guth an em nicht bestat were, so sullen se volle macht haben deme vngehorsamen kinde seyn gut czu entwenden vnde das teil wenden an dy werk der barmherczigkeit noch willin der vormunden vnde ap ich nicht kinder wurde lassen noch meynem tode, so gebe ich desen nochgeschrebenen vormunden volle macht meyn erbe czu vorkawfen vnde andir myn guth vnd das gelt czu geben armen leuthin, wo en das allirbeste geballen wirt; des mach ich mechtige schaffer Swarczpeschken, Petrum Girhardisdorf vnde Kunczonem Habirgeyst vnd Johannem vom Skawin, also ap eyner abeginge, wy ofte das geschege, das dy andern mogen czu en kysen, wer en gefallen wirt, doch wil ich eyn herre seyn meynis gutis, als vor"; SCAB., no. 2070.

221 "Johannes Steynbach domine Clare contorali sue post mortem suam XXX mrc. monete tunc currentis pro dotalicio suo et omnibus aliis, ipsam concernere valentibus, resignavit et ipsa sibi omnia bona econverso"; sCAB., no. $235^{8}$ (1396).

"Hensil Clingner omnia bona mobilia et immobilia uxori sue Elizabeth post mortem suam resignavit et econverso domina dicta viro suo eadem bona resignavit taliter, quod si dicti ambo morirentur cum pueris eorum, eadem debeant bona ad ecclesias converti"; SCAB., no. 727 (1372). 
inheritance of property by children and in the event that a spouse remarried, which brought them closer in form to wills from that period. ${ }^{223}$ An example of the merging of this new formula for acts of last will with a mutual donation is the will of Ursula, Henry Woger's wife, made before she set off on a pilgrimage to Rome. She bequeathed to her husband half of the house and all of the household items and personal belongings in it, one quarter of her house to 'Dorothy', a belt maker (probably a relative), and the remainder of her property to the executors of the will to be used for acts of charity. According to the formula, she retained the right to change the provisions of the will and disinherit all her other relatives. ${ }^{224}$ In return, Henry bequeathed to her after his death all his movable and immovable goods, and also excluded all of his relatives from his will. 225

In the late fourteenth century, a visible change took place among Krakovian burghers in their conception of the nature of wills and the reasons for making them. According to Agnieszka Bartoszewicz: "In the 139os, Krakovian burghers began to build a new bureaucratic machinery: documents, produced independently, were obtained from various offices and officials, collected, and submitted in institutions associated with municipal, land and canon law."226

223 "Nicolaus Hungerkaste requisivit, in sentencia [...]. Idem Nicolaus domine Agneti consorti sue legitime domum suam in plathea Hospitalis, circa domum Nicolai Bochner relicte, post mortem suam contulit et donavit, ita quod ipsa domina pauperibus hospitalis sancti Spiritus in Cracovia dare debet II mrc. annis singulis, quamdiu vixerit et in viduitate permanserit, tenendam et omnia bona sua mobilia et suppellectilia domus omniaque parafernalia, que rade wlgariter dicuntur, tali condicione, quod si bona mobilia [ita bona] quemadmodum ipsius domine dotalicium, quod idem Nicolaus recongnovit facere XXX mrc., non forent, extunc in hereditate predicta, ipsa domina predictum dotalicium poterit recuperare, si autem ipsa domina maritum duceret, aut permittente domino moriretur, extunc domus predicta ad proximos dicti Nicolai, prout de iure debet, devolvatur, qui singulis annis III mrc. dabunt ad hospitale predictum et hoc XXX annis, quousque dicta domus pro XC mrc. fuerit persoluta; reservat dominium"; sCAB., no. 1967 (1394).

"Vraw Ursula cziende ken Rome hot ir testamenth gemacht und bescheyd noch irem tode heynrich woger irem Wirte dy helfte ires heusis, wo sy ynne wonit. Und alle ire vorinde habe und geczew und gerethe und was des ist und Vrawin Dorotheen gorliczynne desselbin hausis eyn Virteyl, und das obengen. virteyl und eyn Werk das Bodyn helt, gibt sy und bescheidit hern Casparn Krugiln und Petir Wochsczagil, dy sy kore czu vormundin, das sy das wendin sullin in dy Werk der Barmheczigkeyt, als sy en getrewit. Und behielt ir dy herschaft, dyweyle sy lebit ane vrunde wedirrede, dy se allhy enterbit"; cons. 427, fol. 151 (1400).

225 "Item derselbige Heynrich Woger hat der egenanten Vrawin Ursulen seynen elichen Weybe al seyn gut beweglichs uud unbeweglichs das her hot adir habin wirt, czu kunftigen czeyt noch seyme tode czu habin bescheyden und gegebin und enterbit alle seyne vrunde unde mogin, das si nichsincht dorezu sullin habin, noch do wedir reden"; Ibid.

Agnieszka Bartoszewicz, Piśmienność, 241. 
This phenomenon and the influence of notaries employed in the Krakow city registry were most likely the forces that led to a standardised formula for making acts of last will and pious bequests to be carried out after one's death. The burgher communal will that came into being in the late fourteenth century combined the prescriptions for: the bequest of a dower; donations to be given to selected family members, relatives and servants; a marriage contract designating the role and place of the wife after the death of her husband; pious bequests for the salvation of the testator's soul; and the selection of executors to carry out these bequests, with the power to decide about the deceased's children and property left in their care. Sometimes the communal will would include some kind of reciprocal clause in the form of a bequest transferring all property to the spouse.

These changes are part of a clearly visible process by means of which the Krakow municipal council assumed responsibility for, and control over, wills. The first information we have about the actions taken by the city authorities in this area comes from a municipal statute approved in 1342 by Casimir the Great. It stipulates that a seriously ill individual, or one going on either a distant or overseas journey or pilgrimage, could, ${ }^{227}$ in the presence of three councillors, choose legal guardians for his underage children and transfer to them custody of his whole estate. ${ }^{228}$ In this municipal statute there is no mention of testaments as such (which were still in general subject to canon law), 229

227 A mention of pilgrimages, distant journeys and overseas travels indicates that a strong interest in its publication was expressed by city elites, who preferred to bequeath their considerable wealth to their friends and to local communities rather than to their relatives, who often lived far away; cf. Marcin Starzyński, "Patrycjat krakowski w aktach Kamery Papieskiej z XIV w. (ze studiów nad udziałem kupiectwa krakowskiego w międzynarodowym transferze finansów)," in Elita wtadzy miasta Krakowa, 333-378.

228 "Que Statuta, Constitutiones atque Arbitria predicta scribuntur in hec verba. Si contingeret, quod homo ita infirmus efficeretur, quod timendum esset de vita sua, vel si proponeret visitare limina sanctorum aut recipere se ad vias longinquas, vel ultra mare, Ille potest coram tribus Consulibus eligere tutores vnum vel plures pro pueris suis, vel pro propinquiribus suis amicis, qui etatem non haberent, et pro omnibus suis rebus mobilibus et immobilibus, quemcumque voluerit, sive sint amici vel Extranei, et hij debent habere plenam auctoritatem et posse, sicut ad hoc essent nati; Et quod idem infirmus sit circa bonam racionem. Et si propinquires illius vellent hoc destruere, non possunt, quousque pueri perveniunt ad Annos quindecim. Sed si femellam infra istos Annos nubere contingeret, tunc Maritus eius ipsius tutelam accipiet hoc statuto non obstante"; KDMK, vol. 3, no. 25 .

229 This thesis was put forward by Bożena Wyrozumska, who believed this statute granted townsmen the right to dispose of all their property. Moreover, she states that: "The council appears to have displayed usurpatory tendencies, since it ruled that the last will could only be made before a councilor"; eadem, Kancelaria, 89-9o. 
but it does mention the practice of the municipal council assuming custody of orphans and their inherited property. This municipal statute significantly limited the rights of more distant family members to be granted responsibility for non-adult relatives and their property, in favour of trusted individuals who were not necessarily related.

In the late fourteenth century, three important factors influenced the formation of the customs and laws that guided the making of wills over the next century. First, during this period wills began to be entered into the books of the municipal bench court and into council books in their entirety, using the wording found on the transcribed statements brought to court. ${ }^{230}$ Second, the municipal council introduced the practice of authenticating wills drawn up in its presence, ${ }^{231}$ and of having two or three councillors visit the infirm with a municipal notary in order to write down and secure dispositions of last will, ${ }^{232}$ which may have been connected with the privilege invoked in the 1393 will of Gottfrid Fattinante of Genoa. ${ }^{233}$ Third, the first book of wills was published, which has not survived to the present day.

The rights guaranteed by the councillors are likely to have been relatively new. In the will of councillor Nicholas Wierzynek the younger, drawn up in

230 Since the book of the municipal bench court covering the $1376-139$ o period has been lost, it is uncertain whether this custom existed earlier; however, the beginnings of this practice is indicated by the fact that in the book of the municipal bench court for 1390-1397, townspeople's wills were first fully recorded only in 1393.

231 For example, the will of George Dubrawka was made in this manner in 1398. "Georgius dubrawka sanus corpore et racionis compos, testamentum suum in nostri presencia consilii disposuit in hunc modum, et primo domine hancze, conthorali sue racione ipsius dotalicii et ceterarum omnium porcionum ipsam in bonis suis concernenium equalem uni suorum puerorum tribuit porcionem. Et quamdiu ipsa hanca in viduitate sua permanserit, debet omnium bonorum dicti Georgii fore domina et eisdem utifrui. Constituit Petrum Kaldherberge bonorum suorum et puerorum tutorem, reservans dominium, quoad vixerit in humanis"; cons. 427, fol. 106 (1398).

232 "Swantag polonicalis licet debilis corpore multum tamen bona perfruens racione in domo habitacionis sue coram dominis Iacobo Mordbir et loh. Puswange consulibus testamentum voluntatis sue ultime condidit in hunc modum, videlicet quod universa et singula bona sua hereditaria et mobilia, quibuscunque nominibus appellentur, que habet aut habiturus est quomodolibet in futurum, domine Barbare conthorali sue legitime post mortem suam habenda dedit, contulit et donavit, exclusis omnibus amicis suis et propinguis, quos de dictis bonis suis omnibus inibidem exhereditavit. Litera est data"; Ibid.

"Propter quod prefatus Gottfridus, prout predictorum presentis testamenti pronunciatorum relacione didicimus, nobis supplicauit pure ac humiliter propter Deum, quatenus diuine iusticie et misericordie intuitu presens suum testamentum ad maioris certitudinis euidenciam nostre ciuitatis authentico, sub quo omnia ratificata et confirmata et presertim legata et testata inconvulse secundum tenorem literarum Ciuitatis priuilegiarium perseuerent, ratificare, approbare et confirmare benignius dignaremur"; KDWac., vol. 2, no.396. 
1426 before the council, it was noted that: "it is a privilege of the city that the testament and last will of anyone, regardless of how much he possesses, can be made before councillors with the same power and effectiveness as if it had been solemnly sworn before the municipal bench court."234 In the same year, Margaret, widow of Nicholas Glezer, brought to the court "the complete and incontestable will of her deceased husband, with a seal affixed to it by municipal councillors, in which it was stated that this Nicholas Glezer, husband of this Margaret, made his testamentary dispositions before the councillors, in accordance 'with the privilege of the city' (iuxta quod est privilegium Civitatis)." ${ }^{235}$ In light of the above, it seems convincing that in the early fifteenth century there existed a now lost privilege or municipal statute in which the municipal council of Krakow reserved the right to write down and authenticate the wills of burghers - acts which, according to a verdict by aldermen in Magdeburg, could only be carried out by a municipal bench court. ${ }^{236}$ Perhaps we are again dealing with the same privilege invoked in Gottfrid Fattinante's will from 1393.

Open and Closed Wills in the Fifteenth Century

The social and cultural changes taking place in the fifteenth century, including the dynamic development of the municipal chancellery, and the initiatives introduced by councillors in Krakow, did not lead to the full standardisation

234 "Dominus Nicolaus Wirzing unus ex nostras presessaribus et senioribus consulibus plena sanitate integra tam in corpore quam mencie iuxta quod est privilegium Civitatis quod quidquod coram Consulibus sic quantumlibet eciam sorte habet esset vel totam vim et omne eandis efficaciam habere debet sicut si cum omni solempnitate coram bannito Judicio publice agetur fecit et disponuit in Consulatu testamentum suum sive ultimam voluntatem in hunc modum"; cons. 428, fol. 231.

235 "Domina Margaretha relicta Nicolai Gleser posuit in Judicium literam testamenti eiusdem olim viri sui sanam et integram et omni prorsus suspicione carentem emanatam a dominis Consulibus Cracoviensis et sigillo appendenti eiusdem Civitatis sigillatam In quam ibidem plane et expresse continebatur quod dictus Nicolaus Gleser maritus dicte domine Margarethe testamentaliter eorum dictis dominis Consulibus disposuit iuxta quod est privilegium Civitatis"; SCAB. 5, fol. 121 (1426).

236 The Magdeburg court's judgements include a description of a mutual will made by two Krakow students that was to be executed in the event of one of their deaths, made before a municipal notary and witnesses "under canon law and custom." After many years, one of them married, and when the other one fell seriously ill, he went to him with councillors and witnesses to confirm the earlier agreement, which he did. After his death, however, the relatives of the deceased challenged the will, and the aldermen in Magdeburg confirmed that such a transfer could only be made before the municipal bench court; Michał Wiszniewski, Historya, 228-229; cf. Bożena Wyrozumska, Kancelaria, 9 o. 
of Krakow's testamentary practices. Although, due to the loss of the city's oldest book of wills, the number of extant acts of last will from the first half of the fourteenth century is unclear, the wills that were entered in the books of the municipal bench court and council books, or which have survived as a separate document, indicate that they continued to display a high level of diversity, both in terms of their function and content, as well as in the formula used. First, there remained a great deal of uncertainty as to what a 'testament' was and what rights were connected with it. This can be seen in, among other places, a bequest from 1405 made by the councillor Lucas Bochner before setting off on a long journey. ${ }^{237}$ In the council book it is written that Lucas, being healthy in body and mind, chose two burghers as executors of his will, which he described as a geschefte testament und zelgerethe, that is, as a will in the form of secular dispositions and a donation for the soul of the testator. $\mathrm{He}$ also instructed the executors to carry out everything indicated for them to do in the will, which had been written down on paper and sealed. This bequest was therefore evidence of the making of so-called 'closed wills,' which were written by a public notary, a privately hired scribe or, occasionally, by the testators themselves, and then sealed and left for the executors to open before the municipal council or municipal bench court after the testator's death. ${ }^{238}$ Examples of this practice can also be found in many other last wills from the fifteenth century. One characteristic example is an entry in the books of the municipal bench court in 1435 concerning the will of Jost the Bowyer. The aldermen testified that they had been visited by Paul the Bowyer, brother of the deceased, his widow Catherine and son Hensel, and three representatives of the bowyers' guild. From the text we also learn that the will was brought to the office by guildmasters and members of Jost's immediate family merely to have its contents authenticated before the court. ${ }^{239}$

237 "Lucas Bochner mit gezundem leibe und guter vornunfft hat gekorn gesaczt und gemacht dy erbarn Casparn Krugiln und Nicolaum Platener czu vormunden schaffern und zundirlichen vorwesern, alzo das se seyn gescheffte testament und zelgerethe, ab an em off dem wege icht geschege, vorwesen, volbrengen und schaffen sullen czutun und czulasen In allir mose und weyse, als se in eyme papirn brife den her en vorsegilt antwortin wirt, werden finden beschrebin"; cons. 427, fol. 240 (1405).

238 Gabriele Schulz, Testamente des späten Mittelalters aus dem Mittelrheingebiet, 5-6.

239 "Bekant haben dy nochgeschrebene personen, daz Jost bogner seyn testament und leczten willen mit guter vornunft gemacht hot vor in nochlaute eyner czedil dy sy uns entwerten in gehegte bank, als, Paul Bogener seyn geborner bruder, Katherina seyne eliche hawsfraw, Hansel seyn son, Meistir Crebis der Bogener, Jungprews der bogener und Peter bogener, und haben dyselben seyne nesten, als seyn bruder, seyn son und seyne hawsfraw dasselbe Testament und schirkunge seyns leczten willens voryowortit gelibt geannemit und ofgenomen in allen stucken das von worte czu worte also lautit”; sCAB. 6, fol. 108 (1435). 
In most cases, testators who wrote down their wills (often with the help of a third party, perhaps an individual who dealt professionally with the written word, such as a municipal or public notary), out of fear of attempts to override their decisions, chose to certify them before the municipal bench court or council during their lifetime. This was the decision taken by John Wole who, being healthy in body and mind (as he himself declared) and in accordance with custom, asked if he could dispose of his non-inherited goods in accordance with his will, ${ }^{240}$ and then presented his 'testament' written down on a sheet of paper to aldermen. ${ }^{241} \mathrm{An}$ interesting bequest in this respect is one made in 1435 by Nicholas Opoczko and his wife Dorothy. They gave each other a house at Sławkowska Street and all their other remaining goods, while excluding all other relatives. ${ }^{242} \mathrm{On}$ the adjacent page there is a full transcription of a mutual bequest in German, copied from a sealed letter. In it we read that Nicholas, being healthy in body and mind, asked if he could dispose of the non-inherited goods he had acquired in accordance with his will, since he had no children or other legal heirs, and that the court ruled that he could dispose of these goods, in accordance with the law. Following this was a mutual bequest of a house and other goods between a husband and wife. ${ }^{243}$ These entries show both what

240 This recurring phrase may be not only a standard formula, but also a trace of some kind of official ritual.

241 "Hannus Wole bey guter vornunft und gesundem leibe frogte im rechtem ap her mit seynen wolgewonnen gute das in nicht anirstorben ist, tuen mag und lossen noch seinem bestin willenund do im das durch uns geteilt was, hot her seyn testament und in eyn czedil vorschreiben geentwert dy also laute"; SCAB. 7 , fol. 32 (1448).

242 "Nicolaus Opoczka Dorothee uxori sue legittime, domum suum in platea Slavkoviensi sitam in qua manet et omnia alia bona sua mobilia et immobilia quecumque habet et que habebit resignavit, Excludens omnes et singulos suos consangwineos et amicos. Reservans sibi dominium quamdiu ipsi viverit. Similiter econverso ipsa domina Dorothea per Michaelem aurifabrum resignavit predicto viro seu marito suo legitimo omnia bona sua mobilia et immobilia quecumque habet aut habebit excludens omnes consangwineos et propinquos, et reservaavit sibi ipsa eciam dominium quamdiu vivet"; SCAB. 6, fol. 110 .

243 "Der irbar man Nicolaus Opoczka unser mitburger keiginworticlich steende gesund des leibes und guter vornunft frogende im rechten ap her mit seym wolgewonnen gute das her mit seyns selbis erbt gewonnen hot und das in von nymande angeerbt noch andirstorben ist, tuen und lossen mochte noch seyme willen, so her keyn kind hot adir elichen erben dorczu, und von uns hir of sulche orteylliche bestetigunge horende, daz her das wol tuen mochte von rechtis wegen, hot of sulch unser ortil und bestetigunge seyn haws of der Slawkischen gasse in deme her wonet mitsampt alle andern seyme gute und habe erblich und farnde beweglich und unbeweglich, das her hot und ummer gewynnet keyns ausgenomen, der irben frawen Doroyhee seyner elichen hawsfrawen noch seyme tode czu haben erblich und mit volkomener macht czu tuen und czu lossen vorreicht und ofgegeben. Und slos aus und schid aus dovon gancz und gar alle seyne frunde, nesten 
a letter sealed by aldermen looked like, in this case one in which a burgher couple made a mutual donation, and indicate that municipal books usually contain abbreviated versions of the recorded acts. Other Krakovian burghers, such as John Phert, whose will was preserved in five different versions, also had their bequests authenticated. In an act confirmed before aldermen in 1445, Phert revoked his previous will and asked about his right to dispose of his acquired property. After obtaining a satisfactory answer, he handed over a sheet of paper with a new act of last will written on it. ${ }^{244}$ Wills were also often authenticated in court by people going on a longer journey or pilgrimage, such as Michael Molner in $1444{ }^{245}$

A list of fees charged by the municipal notary for his services, entered into the pages of the council book in 1435, also indicates that the custom of councillors and (later) aldermen visiting the sick was a common practice. We find the following entry: "For going to [witness] a will -6 groszy [Wenn man geet czu Testamente $6 \mathrm{gr}$ ]." This entry both confirms the municipal notary's participation in visits by members of the municipal council "to a will," and indicates that a slightly higher fee than usual was charged for writing the will down

und mogen, und behild im dy herschaft dy weyle her lebit, und frogte ortil und recht. So her keiginwortig stunde und seyner hawsfrawen sulche gobe tete, und ir also ofgebe, ap is bund und kraft sulde haben, ader was do recht were, und dorof habe wir czu bestetigunge eyn sulch ortil und recht ausgesprochen, daz sint der czeyt daz her keiginwortig steet mit gesundem leibe und mit guter vornunft und mit wolbedochtem mute und seyner hawsfrawen ofgibt seyn haus und alle seyn gut als obene, und slewst aus dovon alle seyne nesten mogen und frunde, so sal is bund und kraft haben von rechtis wegen, und dy ofgobe enpfing dyseben fraw durch Michil Goltsmed unser mitbruder obgenanten den sy ir dorczu gerichticlich czu vormunde nam, und dokegen hot dyselbe fraw Dorothea durch denselben iren vormunden deme obgenanten iren manne Nicolao Opoczka hinwedir ofgegeben allis das sy hot adir ummer gewynnet is were beweglich adir unbeweglich, und wy man das genommen mochte noch irem tode czu haben, und slos aus dovon alle ire nesten mogen und frunde, und behilt ir ouch dy herschaft dy weyle sy lebt, und das ist abir mit ortil bewert, und durch uns bestetigilt alse recht ist noch forma des gerichtis als obene"; SСАв. 6, fol. 111.

244 "Hannus Phert revocavit testamentum quod prius fecit in tote et confecit aliud testamentum ut sequitur infra. Hannus Phert gesund des leibes und seyner vornunft steende, frogte umb ortel und recht, ab her mit seyme direrbtin und wolgewonnen gutte tuen mochte und lossen noch seyme willen do wart em gerichtlich ausgesprochen daz her tuen mochte und lossen noch seyme direrbtin und gewonnen gutte noch seyme willen. Do legte her vor uns in gehegte ding eyne czedil, dy von worte czu worte lauth also"; SCAB. 6, fol. 342 .

245 "Michil Molner unsir miteburger gesunt seynes leibis mit gutter vornunft wellinde besuchen dy heiligen Czwelfboten sinte Peter sinte Paul czu Rome seyn Testament und lecztin willen beschreben in eyner czedil hot nedirgelag, dy von worte czu worte lauth also"; sСAв. 6, fol. 321. 
in the patient's home. In other articles of the municipal statute, it is stated that the municipal notary is entitled to one grosz for an entry made before the municipal bench court and four groszes for a letter written on parchment before the municipal bench court or council, unless it is a letter containing a privilege or a 'large will' (grosse Testament), for which a larger sum of money could be collected. ${ }^{246}$

The list of notarial fees from 1435 suggests that the term 'large will' was used in reference to wills made in the form of documents written down on parchment and often stamped by city authorities. The few wills preserved in this form clearly reveal their religious character, and that their form was still strongly influenced by that of the 'canonical will.' This is most clearly visible in Claire Rolle's will from $1419 .{ }^{247}$ Written down on parchment by the public notary John Stolle of Głogów, ${ }^{248}$ 'the will' (tabula testament) begins with the invocation $[I]$ n nomine Domini amen, which, apart from in this will, appears only in Sulisława's will from 1303 and in the testaments of clergy members, such as that of the Krakovian presbyter Theodoric Weinrich, written in $1449 .{ }^{249}$ Next, the date was placed in accordance with the form used in notarial documents. It is then noted that:

[I]n the city of Krakow, in the presence of a notary and the following personally appointed witnesses [priests from churches to be gifted by the testator] Claire, widow of Jacob Rolle, in her home, being healthy in body and mind, guided by fervent piety, wishing to devote her goods to the worship of God, which is the most befitting of the works of charity, and out of thanksgiving and love for the beloved supplier and donor of all goods, and for the salvation of the souls of her and her deceased

246 "Von Scheppinbrifen und Ratisbrifen of permynt IIII gr. Ausgenomen grosse testament adir Vorrichtbrife, do von mag her me nemen [...]. Wenn man geet czu Testamente VI gr"; CONS. 428 , fol. 348 .

247 At the time of writing her will, she had been for many years the widow of the wealthy Krakow bowyer Jacob Rolle, whose will was entered in the book of the municipal bench court in 1392; SCAB., no. 1425 .

248 John Stolle signed the document as a priest from the diocese of Wrocław, and certified it with his personal notarial seal: "Et ego Iohannes Nicolai Stolle de Glogouia maiori, Clericus wratislauiensis diocesis, publicus Imperiali auctoritate Notarius, dicte voluntatis disposicioni interfui vna cum testibus iam nominatis hic supra, et eam totaliter et omnimode in sensu quidem, sicut supra hic notatum est, loquente domina predicta et scedulam exhibente, tunc ibidem audita percepi et uidi, et manu mea in hanc formam scripsi, Signo meo et nomine solitis consignatam"; KDMK, vol. 3, no. 406; for more on John Stolle, see Bożena Wyrozumska, Kancelaria, 121. KDMK, vol. 3, no. 368, 493-494 (1303), no. 406, 532-534 (1419), no. 432, 563-569 (1449). 
husband, who died without making a will, 250 other than leaving to her the making of pious bequests, which were to be made and allocated from her property... ${ }^{251}$

In accordance with this declaration, numerous pious bequests are then mentioned, including the bequest of a tenement building to establish a new foundation to maintain the altar to Mary Magdalene in St. Mary's Church. The testament ends with a noteworthy statement: "she wishes that in order for this disposition of her will to be confirmed and better secured as a testament or legacy, or at the least, as a legal codicil, or any donation from her last will, or in accordance with the law, the current circumstances, or what is customary, that all of these things be made a public document by me as a notary."252 This provision not only signals the existence of uncertainties concerning the legal underpinnings of wills and the means for ensuring the

250 Jacob Rolle left behind a provision in which he bequeathed all of his possessions to his wife, obliging her to donate 100 grivna to help the poor. It is possible that his widow decided to secure the salvation of her husband's soul only many years later in her will. This bequest indicates that as recently as the early fifteenth century, the will was primarily considered a religious act; cf. "Jacobus Rolle domine Clare eius consorti legitime post mortem suam universa bona sua hereditaria et mobilia, que habet et postmodum habuerit, exclusis omnium suorum propinquorum contradiccionibus, si et inquantum ipsa domina vidua permanserit, libere resignavit, de quibus bonis centum marcas infirmis in hospitali et aliis pauperibus debet distribuere cum effectu, si autem de novo maritum contraxerit, extunc tutores infrascripti eidem domine centum sexagenas donate debent cum plena faciendi et dimittendi facilitate, debent eciam eidem tutores domine Katherine eius filie, Johannis Reyman consorti legitime, similiter centum marcas donare et effectualiter post dicte domine Clare obitum assignare. Tutores Nicolaus Gemlich et Johannes Frienstat; premissis"; SCAB., no. 1425 (1392).

251 "In nomine domini amen. Anno nativitatis eiusdem millesimo quadringentesimo decimo nono, Indiccione duodecima, Pontificatus sanctissimi in christo patris et domini, domini Martini diuina prouidencia pape quinti anno secundo, Veneris die duodecima mensis May, hora vesperorum, In ciuitate Cracouiensi, In presencia mei notarij et testium infrascriptorum personaliter constituta honesta domina Clara relicta Iacobi Rolle, In domo sua, sana corpore et bone racionis, zelo pietatis ardenter cupiens facultates suas ad cultum diuini numinis disponere, quippe qui saluberrimum sit operum caritatis, ac pro gracia et amore amantissimi datoris et remuneratoris omnium bonorum et in remedium et salutem anime sue atque dicti quondam eius mariti, qui decedens testamentum aliud non fecit, nisi quod ipsum disponendum eius fideli reliquit voluntati, Voluit dari et mandauit de bonis suis"; KDMK, vol. 3, no. 406, 532-534 (1419).

252 "Et hanc suam voluntatis disposicionem ualere uoluit ut testamentum vel legatum aut saltim iure codicillorum, aut donacionis cuiusuis ultime uoluntatis, aut prout alias de iure uel de facto uel de consuetudine melius subsistere poterit et valare, petens sibi super his a me Notario fieri publicum Instrumentum"; Ibid. 
implementation of their provisions, but also reflects a utilitarian approach in the legal recommendations it makes. Broad-ranging similarities between the form of this will and the purpose for writing it down and those of other wills preserved as notarial instruments, both the last wills of clergy members, like that of presbyter Theodoric Weinrich, ${ }^{253}$ and those of the gentry, like the last will (made in Lublin) of the Starost ${ }^{254}$ of Brodnica, Francis Gliwicz from Krakow. ${ }^{255}$ It seems, however, that for burghers, both those who were members of the elite and ordinary members of Krakovian society, it was usually sufficient for wills to be made in the form of a document produced before a municipal council or bench court in a much more abbreviated form.

Some burghers, especially during epidemics of infectious diseases, made their wills not in a closed form or openly in the town hall, but in private in the presence of their friends, neighbours, or fellow members of guilds or brotherhoods. In 1443, ten masters from the furriers' guild appeared before the municipal council to testify on behalf of their fellow tradesmen that the late guild member John Baumgart had given, 256 "as a testament" for building and funding a new chapel in St. Mary's Church, 40 grivna, which was owed to him by Nicholas Schretil. Accordingly, the furriers' guild secured the money from the debtor and used it to fund the chapel. ${ }^{257}$ Similarly, in 1475 three senior members of the salt merchants' guild (sallicide) testified that the deceased Peter Romanus owed fifteen florins to Martin Swetcz from Mazovia. ${ }^{258}$ In the Liber

253 KDMK, vol. 3, no. 432, 563-569 (1449).

254 See Glosary: Starosta

255 "Et Ego Iohannes Andree de Gorzicze Clericus Poznaniensis diocesis, Notarius publicus Imperiali auctoritate, Reuerendissimi in christo patris et domini, domini Iohannis dei gracia Episcopi Cracouiensis Causarumque et facti huiusmodj coram sua peternitate Scriba, Quia predictis Testamenti siue Codicilli reposicioni, testium Induccioni, Recognicioni, Peticioni, confirmacioni et ratificacioni, Alijsque omnibus et singulis premissis, dum sic vt premittitur agerentur et fierent, vna cum prenominatis testibus interfui, Eaque omnia et singula premissa sic fierj vidj et audiui, Ideo presentes Confirmacionis literas siue presens publicum Instrumentum manu mea propria scriptum confeci et in hanc publicam formam redegi, Signo et nomine meis solitis et conswetis vnacum appensione Sigilli dicti dominj Episcopi Cracouiensi et de eius mandato speciali consignans, In fidem et testimonium omnium et singulorum premissorum"; KDMK, vol. 3, no. 474, 624-626 (1484); for more about the Brodnica starost Francis Gliwicz from Krakow and the 'Old Horse' coat of arms, cf. Feliks Kiryk, Zarys dziejów osadnictwa, in Dzieje Olkusza i regionu olkuskiego, vol. 1, eds. Feliks Kiryk, Ryszard Kołodziejczyk (Warszawa, Państ. Wydaw. Naukowe, 1978), 107.

256 "Niclas Cleynhoze, Thomas Czan, Niclas Czipser, Antonius Meilner, Petir Ar, Petir Kaufman, Mathis Schretil, Lazarus Poneczky, Bartholomeus Tretkopi John Konynsky seniors pellificum"; cons. 428, fol. 466 (1443).

257 Ibid.

$25^{8}$ CONS. 429 , fol. 543 (1475). 
Testamentorum there is a bequest from 1482, a time of plague, which states explicitly that the tailor John Biały, being healthy in body and mind, made his testament before the elders of his guild. A year later, the will was placed in the book of wills, most likely as a result of the actions of the executors of the will.259 The following year, John Wilki and Martin, two guards of the city's gates testified before the council that they were witnesses to the will made by John the Master, who chose Benedict the furrier as his will's executor. These two witnesses testified before the council to the honesty of Benedict, who was accused of misappropriating the money, claiming that he had properly carried out the provisions of the last will, giving the money to monasteries and brotherhoods in Krakow and to a woman. This entry shows that John's will was not authenticated before any office, and that its authenticity could be attested to only by means of oral testimony. 260

Magdeburg Law theoretically only allowed people who were healthy in body and mind to dispose of movable and immovable property before the municipal bench court. However, in the late fourteenth century, Krakow councillors started the practice of visiting sick burghers to witness their last will and guarantee its fulfilment. In order to safeguard wills made in the presence of council envoys - usually the mayor and two or three other councillors - they were recorded in council books, including special 'books of wills' that were kept by the municipal council. One of the first examples of this practice is the fifteenth-century will of Dorothy Pauswanginne, written in 1405. The entry concerning this act begins with the statement that Dorothy's will was written down "word for word" in the council book by order of the municipal councillors. It reads as follows:

We Nicholas Bochner, John Borg, Peter Meinhard, Nicholas Platener and Matthias Arnsberg, councillors of the city of Krakow, declare to all those who so require, that sitting here before us on the council, councillors Hartlip von Klucze, John Czopchin and John Falkinberg testified that at our

\footnotetext{
259 "Byaly Jan sartor condidit testamentum suum ultime voluntatis die dominica in vigilia divisionis appostolorum Anno Domini MCCCCLXXX secundo, sanus mente eger Corpore presentibus senioribus artificii videlicet Johanne Mroczek, Jarosch, Stari Niclos, Laurencio Prazak et Girzik quos executores testament constituit”; LT, fol. 133-134 (1482). 
request and by virtue of their council office [von unser bevelunge in crafft ires Ratampts] they went to Dorothy, widow of John Pauswang. Dorothy, being of sound mind, in the presence of these councillors and through her chosen guardian John Ederer made and disposed her testament, a bequest for the soul and the last will... ${ }^{261}$

It follows that as early as 1405 council "visits to the sick" were perceived as a normal part of a councillor's obligation. In later years, the testimonies entered in the council books often contained information about sending to the sick three councillors "at special request," who wrote down the testimony of a person's last will and then brought it to the full council for authentication. ${ }^{262}$ This practice soon acquired the authority of antiquity, as seen in a passage in the will of Margaret Glezerinne (the above-mentioned widow of Nicholas Glezer) from 1428. The visit of three members of the municipal council to the sick woman was described as 'the old custom of our city' (alder gewonheit und haldunge unser Stat). ${ }^{263}$ The same term was used in this context in the bequests of Erhart Eigilwart, an alderman from Augsburg, in 1431, ${ }^{264}$ and of the former Košice burgher John Czenmark in 1436. ${ }^{265}$

261 "Tenor litere testamenti domine Dorothee Pauswanginne de verbo ad verbum hic notatis est ad mandatum dominorum. Wir Niclos Bochner, Hannos Borg, Petrus Meynhard, Niclos Platener und Mathias Arnsberg Ratmannen der Stat Cracovia Bekennen allen den is notdurft ist,daz vor uns in siczczinden Rate, die ersamen Hartlib von Klucze, Johannes Czopchin und Johannes Falkinberg unsir mitRatmannen und eyrgenossen habin offimberlich und eyntrechticlich bekant daz alz se von unser bevelunge in crafft ires Ratampts, czu der erbarn frawen Dorothean Johannis Pauswangin witwen gegangen woren, do hat diselbe fraw Dorothea vor en alz Ratmannen, mit wolbedochtem mute und guter vornunfft, durch Johannem Ederer iren doselbist gekornen vormunden Ir testament zelgerethe und leczten willen, gemacht geschickit, gescifftit und geordnit in zotener weyse"; CONS. $427,[.241$ (1405).

262 Such an annotation can be found in the wills of Young Peter the tanner (Jung Petir rufficerdus), CONS. 427, fol. 354-355 (1409); Stanisław Leytman the younger, CONS. 428, fol. 23 (1414) and Michael the butcher (smersneyder), cons. 428, fol. 120 (1419).

263 "Wir Peter Fetter, Jorge Swarcz, Wilhelm Willand, Peter Grazer, Dithrich Weynrich, Bernhard vom Brige, Hannus Hoze und Nicolaus Alberti Ratmanne der Stat Cracow Bekenne offintlich mit desim brifem daz als dreye aus uns gesant und gegangen weren von des ratis wegen als her Peter Fetter, her Jorge Swarcz und her Peter Graser czu der irbarn frawen Margrit Glezerynne czu verhoren ir testament und schicunge ires leczten willen, noch alder gewonheit und haldunge unser Stat, do hot dyselbe fraw Margrith Glezerynne in krangheit leggende ader bey guter vornunft wesende ir testament vor In gemacht und lossern beschreiben als sy vor uns bekant haben in sulcher worten und also"; cONS. 428, fol. 243 .

264 CONS. 428 , fol. 305 .

265 CONs. 428 , fol. 354 . 
An interesting phenomenon that seems to have occurred sporadically during this period was the making of wills by ailing burghers in the presence of Krakow aldermen. The fact that this situation was exceptional is evidenced by the fact that only a few wills have survived to our times that are known to have been written down in such circumstances. The first mention of this kind can be found in the will of Anna, widow of the councillor John Bartfal. ${ }^{266}$ In an entry from 1419 it is noted that councillor John Plesner, when he was still a alderman, along with the aldermen Nicholas Bastgert and Nicholas Szwarczhensil, testified together with vogt Nicholas Schaffer, that due to Anna's illness, they had held an open court (iudicium bannitum) in her house, before which she bequeathed through her chosen guardian John Plesner three grivna in rent to St. Mary's Church. ${ }^{267}$ It is worth noting that this act of last will was entered into the council book, and not into the book of the municipal bench court, probably at the request of John Plesner who she had chosen as the executor of her will. The precedent-setting character of this case was probably influenced by the nature of the disposition, which was a generous bequest to St. Mary's Church, an institution supported by the city authorities. The social position occupied by the widow of an influential Krakow alderman was probably also not without significance.

Information about another will, made in a similar fashion, but this time entered into the book of the municipal bench court, dates back to 1466. Like Anna Bartfalowa, Bartholomeus Graudencz was also closely associated with the city authorities, having served for many years in Krakow as a alderman. In this case as well, aldermen testified that they went to the sick man's house, where, together with mayor Hartlip Parchwicz, they held an open court (gehegt ding). ${ }^{268}$ Before them Bartholomeus distributed his extensive estate between his wife Margaret and the children of Nicholas Dittrich and gave an account of his debts and liabilities. ${ }^{269}$ Interestingly, in both of the above acts the word

266 He is listed as John from Bardiow in the register of the Krakow councillors compiled by Marcin Starzyński; Marcin Starzyński, Krakowska rada, 247.

267 "Johannes Plessener noster Consul alias Scabinus, Johannes de Sale, Nicolaus Bastgerth, et Nicolaus Swarczhensil tunc eciam scabini Regognoverint sub iuramento ipsorum, Quod cum ipsi cum Nicolao Schaffer Advocato, Judicium in domo habitacionis domine Anne Relicte Johannis Bartfal propter ipsius corporis debilitatem bannunssent tunc dicta domina Anna dicto Johannes Plessenen pro tutore recepto coram eodem iudicio banito III mrc census terragii perpetui in et super domo Ilkusserinne in plathea sancti Floriani sitis fratrum ad sanctam Mariam Ecclesie parochialis Cracoviensi resignasset iure hereditario"; CONS. 428, fol. 123 (1419).

268 See Glossary: Bench court

269 "Wir Scheppin der Stat Cracow bekennen offintlich mit desim brife das wir of sunderliche begerunge und bete des Erbern Bartholomei Grawdencz unsirs libin mitbruders geruchtin czu im In seyn haws czugeen do selbist wir komende der do leginde was In 
'testament' itself is not used. It does appear, however, in a bequest made in similar circumstances a year later by Nicholas Wishube. The aldermen here testified that together with mayor Hartlip Parchwicz, "at the special request" of Nicholas, they held court in the sick man's house. It may be assumed that the granting of the act as a "testament and last will" was related to the fact that (unlike Graudencz) Nicholas Wishube made many pious bequests to benefit churches and hospitals in the Krakow agglomeration. ${ }^{270}$ The book of the municipal bench court from the same year also contains the will of the Mayor of Krakow, the aforementioned Hartlip Parchwicz, in whose house court was held by the Vice-Vogt (untervogt) ${ }^{271}$ Michael Opoczko and the aldermen Matthias Apteker, John Gartner and Nicholas Gobil. This bequest of last will was entered onto the pages of the book in a slightly different form than the previous ones. Only at the end of the entry does information appear that it was written down in the home of the ailing Parchwicz. ${ }^{272}$ All three wills mentioned above come from the years 1466-1467, when a great plague was rife in Krakow, which may in part explain the special measures taken by the aldermen and their assumption of duties that had previously been the responsibility of the municipal council. Few testaments have survived that were written down in the presence of Krakow aldermen and contain an annotation that they were made by infirm individuals. It seems, however, that in this regard the 1466 plague could have been a transformational event that changed the municipal bench court's approach to wills. This is indirectly indicated by the bequest of last will of the merchant John Raisser from Memmingen (southern Germany),

crangheit in seynen Stuben also of seine begerunge wir eyn not gehegt ding gehegit habin In welchim dinge der Ersame her Hartlip Parchwicz unsir foit sas, der obgenante Bartholomeus Grawdencz wy wol her swachis leibes gewest ist, idach seiner guttir vornunft gebrawchende doselbist vor unsirm gehegtim dinge sitczende hot eyne solche gobe und bekentnis gegebin und geton hot"; SCAB. 8, fol. 246.

"Wir Scheppin der Stat Crakow bekennen offintlich mit desim brife das wir of sunderliche bete und begerunge des Erbern Nicolai Wishubes unsirs mitburgers geruchtin czu im In seyn haws czu geen Also do wir komende woren der do leginde was In seynem hawse of seyne begerunge doselbist wir eyn not gehegt ding gehegit habin, In welchim gehegtim dinge der Ersame her Hartlip Parchwicz unsir foit ses der obgenante Niclos Wishube wy wol her swachis leibis gewest ist idach wesinde bey guttir seynir fornunft und mit wol bedochtim mutte vor dem selbin gehegtim unsirn notdinge her seyn Testament und schickunge seynes lecztin willes also gemacht hot"; sCAB. 8, fol. 250 (1467).

271 See Glossary: Vice-Vogt

272 "Hec omnes recogniciones et _ prout superius continent __ _ per dictum Hartlip infirmium et langwentem in domo habitacionis ipsius ubi ad ipsius peticiones Judicium Bannitum per Scabinos est celebrantum"; SCAB. 8, fol. 269 (1467). 
who came to Krakow in 1476 . The holding of a session of the municipal bench court at the house where he was staying was this time described as 'our custom' (unsir gewonheit). ${ }^{273}$ Moreover, unlike in previous wills, where they were simply referred to as open courts (iudicium bannitum, or gehegt ding), here the expression notding is used, ${ }^{274}$ i.e. a 'extraordinary court' (iudicium necessarium), that is, a court hearing called in special and urgent situations.

What were initially exceptional, for aldermen - the occasional hearing and recording of the last wills of members of the city elite - became with time an increasingly frequent practice (especially during epidemics, when council members often left the city walls). The extraordinary jurisdictions of municipal bench courts included cases requiring immediate intervention. It is surprising, however, that although the concept of an extraordinary court existed in Magdeburg Law from at least the fourteenth century, ${ }^{275}$ it was used for the first time in the context of the last will of an ailing individual only in the latter half of the fifteenth century. ${ }^{276}$ It seems that to some extent this phenomenon

273 "Wir Mattis Apteker etc. Scheppin der Stad Crakow bekennen offintlich mit desim briffe vor allen und iczlichen dy en sehen ader leszin das so wir off sunderliche bete und beger des Erbarn und Czuchtigen Hannus Rayssir von Mammyngen czu ym gegangen weren in das haws des namhaftigen herren Sebastiani Fogilwedirs unsirs mitburgirs in seyn gemach do her sichet und in crangheyt gelegen hot czu vorhorchen seyn Testament und schickunge seynis letczsten willen und do selbist noch unsir gewonheit vor em eyn notdingt gehegit hatten. So hot do selbist vor uns in gehegtdinge das der Erbar Stanislaus Steynbach unsir ffoyt sasz der selbe Hannus Raysir in crangheit leginde und swachen des leibis ydoch bey guttir voller vornunft wesinde mit wolbedochten mutte und mit gancz vorsatcz und willen seyn testament gemacht in sulchir geschicht also her noch folgit"; SCAB. 8, fol. 598-599.

274 See Glossary: Bench court

275 "In practice there ocurred incidents requiring the court's immediate intervention. In view of the fact that high and ordinary courts were held only on certain dates, Magdeburg Law created a type of court convened on an ad hoc basis, called a notding" Witold Maisel, Sadownictwo miasta Poznania do końca XVI w. (Poznan: Wydawnictwo naukowe PwN, 1961), 30-31; According to Witold Maisel (referring to Wiktor Friese), townspeople were given permission to appoint such a court in the location privilege of Poznan as early as the mid-thirteenth century. The term notding as a court of emergency to judge the case of a 'guest' or person embarking on a journey is also used in the Code of Magdeburg Law of 1389.: "Ap man gesten notding hegen sal adir burgir kegen gaste," Ibid.

276 One of the Magdeburg judgements sent to Krakow in 1382, includes a mention that John Czetirwange, a Krakow townsman, made his last will and testament before an emergency court (notding), which was later confirmed during regular proceedings of the bench court. According to this note, however, it was made by a man who was physically and mentally fit. It may have been connected with a plan expressed by John in 1373 to embark on a pilgrimage; cf. SCAB.K, no. 812. According to the Magdeburg bench court's decision, 
can be associated with a growing understanding of Magdeburg Law and a more faithful adherence to its letter. ${ }^{277}$ It is also possible that the dissemination of wills among broader circles of urban society - connected with a growing sense of danger from the plague in the latter half of the fifteenth century - resulted in a gradual transfer of jurisdiction over wills into the hands of the bench court and hearings conducted by the emergency court. ${ }^{278}$

The growing importance of making and authenticating wills before the municipal bench court in the latter half of the fifteenth century is also indicated by the bequest of last will of the municipal notary Christopher Rebentcz, who, before going to Wrocław in 1481, drew up an act of last will before the municipal bench court "in accordance with city law" (noch der Stat recht), but confirmed it before the municipal council only after returning from the journey. ${ }^{279} \mathrm{~A}$ similar situation also occurred in the case of Peter Schepcz's will from 1483. The document, handwritten by the testator, was later authenticated by him before the municipal bench court, but it was only after his death that the chosen executors decided to enter it into the Liber Testamentorum. ${ }^{280}$ However, the absence of two books of the municipal bench court from the years 1476-1500 makes it impossible to fully confirm these observations on the basis of primary source materials.

such a provision could not be questioned by the wife of the deceased; Kodex Pilźnieński ortylów magdeburskich. Odbitka z II tomu Sprawozdań Wydz. Hist. Fil. Akad. Umiejętn., ed. Władysław Wisłocki (Krakow: Akademia Umiejętności, 1874), 6o-64.

This phenomenon can be observed in the growing number of testamentary bequests made and confirmed - in accordance with Magdeburg Law - before a municipal bench court, rather than before the municipal council, as well as in the wills found in the late fifteenth-century Liber Testamentorum, including references to the council's privilege to accept and confirm these documents, which may point to attempts made at this time to contest this law.

278 In his description of the functioning of extraordinary bench courts, Witold Maisel referred only to examples from the sixteenth century; cf. idem, Sadownictwo, 80-81.

279 CONS. 429, fol. 693 .

280 "Herren Ulricus Jeczinbergir und Stanislaus Lanthman gekorne vormunde Petri Schepcz Testament dem got gnade legeten vor uns vedir des selben Petri Schepcz Testament welche her bey gesunde leibe und seynir eygen hant geschriben hat und vorsigilt in unsir gerichte den Scheppen ingelegit hat In sulcher weyse, worde got obir yn etwas todis halbe thuen das is bunt und craft sulle haben sam is in der Scheppen buch wen geschreben noch ynnehaldunge unsir Scheppen bucher begereten von uns das is solte werden gelesen und dorch uns mit unsirm buche och worde bestetigit welchis gelesen wart in keginwortikeit der obgenanten czwir vormunde und Petri des obgenanten Petri Schepcz Eldistir zon und lawtet von worte zu worte"; LT, fol. 137 (1483). 


\section{Formula for Wills from 1485}

An extremely important, though quite late, example of an attempt to standardise the formula used in acts of last will written in Krakow is the following testamentary form, which has survived to the present day. ${ }^{281}$ It was written on a single sheet of paper in German, probably in 1485:

Jesus, Mary. In the name of our Lord Jesus Christ. Because almighty God has made human nature weak, so that man cannot escape death and the hour of death comes to him unseen, so that man must always be ready to accept the hour of death, just as he appeared in this world, and so man should distribute and pass on his goods which God has lent him, so that by God's grace he can allocate them for the salvation of his soul. With this in mind, I, P.K., a burgher from Krakow, with careful consideration and goodwill, being healthy in body, in accordance with which I can dispose I make this act of last will with careful consideration and in good faith, so that I have not made any other will after it, in all respects the best protective form known and in accordance with the law, as I could have done and disposed of, every regulation point by point, as follows:

First of all, because almighty God has made me mortal and in death I will depart, I thus entrust my soul to almighty God and his mother Mary and all the heavenly lords, and my body to the earth, where it should be buried according to the Christian rite, should be commissioned for love for almighty God and for the salvation of my soul.

If, after my death, my children are to assume my legacy, remaining in love and friendship, and none of them shall demand anything more, then I the sole father of all my children and sole owner of all my possessions, which I can legally dispose of according to my will and judgement, shall share and dispose of it, and it is my last will, that all my movable and immovable goods, which God has lent me, in all places and confines where they may be found, which I shall leave behind me, in its entirety should fall to my heirs in accordance with these instructions, which I have written with my own hand and confirmed with my seal. Just as if it had been made before a council meeting or before a municipal bench

281 Elżbieta Piwowarczyk did not recognize this document as a testamentary form, and instead considered it to be an actual will: "in the ruling of a Krakow councillor using only the initials P.K., in the early sixteenth century."; eadem, Legaty testamentowe ad pias causas, 69 . 
court. Then, I bequeath for works of charity, etc., and other things. For this I choose executors.

These dispositions are issued in the form of a testament by me, P.K., and thus made and recorded, I give them to councillors (or aldermen) of the city of Krakowto keep and safeguard during my lifetime and to have executed without objections by any persons, while after my death it is to be given to my children and heirs in their or their guardians' presence, and they are to confirm it. And it will be additionally safeguarded in the municipal book in order for it to have authority and force in all matters.

As long as I shall live, in all these matters I retain the power to change, improve, increase or reduce anything in accordance with my will.

Testament made in German [Lat.]. ${ }^{282}$

282 "Jesus Maria. In dem nam unsers herren Jesu Cristi. So der Almechtigen gott dy menschliche nature sweblich geschossen hot also das der mensch dem tode nicht entgeen mag und ym dy stunde des todis geen verborgen hot auff das das der mensch alle czeit bereit sey dy stunde des todes an zu nehmen So her von diste werlt gefundert wirt Auch das der mensch zeyne gutte dy ym gott vorlihen hott, also vorschafferbenen und ferschaffen sal, das her der durch gotis genode von seinir sele selikeyt enlangen mochte Das betrachtunde, hab Ich P K burger zu Crake mit gutten czeitigen vor rote, auch wol bedochtem wille, gesunt des leibes do ich das wol gethon mocht awss rechte vornunfft und redlichen vorsachen mich dorczu bewegende dass meyn geschofft an stadt meynes leczten willes, so ich keyn andern testament noch dem machen worden In aller besten brefftigensten und bestendigensten form undemunge weise und recht so ich ynnee tun kann und mag, gemacht und geordent hab, Setcz schaff und verorden von stuck zu stuke als her noch folgt. Czum ersten so der almechtigen gott mich von diste immortall erfordert, und ich mit todt abgegangen bin, so befel ich meyne zele dem almechtigen got und seiner werder mutter Marien und dem gancze hymelschen here, und meynen leichnam zu der erden welchs mit cristliches erberkeyt sal bestalt werden dem allmechtigen gotte zu lebe und meyner zele selikeyt; Item das noch meynen tode meyne kinder und erben ader erb nehmen in eynikeit libe und fruntschafft bliben und eyns das ander nicht hett vorummb anzulangen Zo ich eyn vattir allen meynen kinder und eyn her meynes wolgewonen guttis byn und hab folkomener gewalt von rechte der mit zu thuen und zu lossen noch meynen eille und besten erkantnisse, so shikich und schaff und ist das men leczten will, das alle meyne habe und gutte dy mir gott verlihen hott, ligende und farende in allen orten und enden vor dy gefunden werden dy ich noch mir lossen worde keyns ausgenomen nich hynden an gesatcz sollen von meynen linden und erben also angenomen werden in kunfft dists geschefftis welches ich mit meyner eygener handt geschreibh hab und mit meynen pitschaffte vormacht und vorsigelt Gleich sam ys vor gesassenen rote adir vor gerichte gemacht werre her noch folget. Item in dy werk der barherczikeit vorschaff etc. tem ander dinge etc. Dornoch executores und vormunden; Diss gescheffte und ordenunge an stadt eynes testamentis von mir P K also gemacht und geschriben gib ich dem ersamen rote (ader dem scheppen) der stadt Croke zu behalden und zu bewonen bey meynen lebetagen zu meynen gutten willen und ys wider_ben um von yne zu fordenen und zu namen von ich will an allen hindernisse irkeynen menschen Sunder noch meynen tode sal ys gegeben werden meynen kindern und erben so sy das kegenwertigdurch 
This form was written by the hand of the long-time deputy notary of Krakow Kacper Grosz. ${ }^{283}$ The initials P.K. on the form, however, may also refer to the author of the original will, which provided the model for the municipal notary. Interestingly, there is not a single will from Krakow with an equally extensive invocation and preamble or such flowery phrasings. We thus do not know whether the original was the work of a Krakow burgher, or whether it came from another source. ${ }^{284}$ The question therefore remains open as to whether this formula is evidence of an attempt by the municipal chancellery to introduce in Krakow an expanded form of the burgher will, with a formula modelled on wills drawn up in the form of notarial instruments. It is also possible that some wills drawn up as a written document in the latter half of the fifteenth century were similar in form, but were entered into the municipal book or Liber Testamentorum in a significantly simplified form. As early as 1888 Bolesław Ulanowski noted that:

Anyone who has read our court books has often met with the expression at the end of a bequest: ut in forma. This means that the notary did not adorn the act with all the stylistic accessories, but summarising it briefly in the court protocol, confined himself to drawing on the relevant formula for such a matter. If, on the basis of a court bequest, it was appropriate to issue a document (litteram iudicialem), then the relevant formula would have been used in its entirety.285

In the case of wills, it was also the custom of municipal notaries to simplify the documents presented to them for authentication. This phenomenon is evident in the case of Kunil Gluk's will. His last will has survived both on the original sheet of paper and in the form of an entry in the book of the municipal bench court from 1394. In rewriting the original text, the municipal notary omitted a very short promulgation of the act, leaving only the first and last name of

sich ader iren vormunden und in abwesen durch eyn iren anwelden gefordenen und heischen werden Idoch das ys bestetiget wirt und in stadt buch ingeschriben das is bundt und krafft haben solde allenhalben; In dem allem behalde ich mir dy herschafft dy weile ich lebe das zu wandeln zu bessern zu meren zu mynden noch meynen wille und wol gefallen; Testament in wulgari faciendis"; AMK, ms 779 .

283 Agnieszka Bartoszewicz, Piśmienność, 147-148.

284 Kacper Grosz allegedly spent some time in Venice, but it is not known for what purpose; Ibid., 148.

285 Libri Formularum saeculi XVmi, ed. Bolesław Ulanowski, Krakow 1888 (Starodawne Prawa Polskiego Pomniki, 10), vi. 
the testator. ${ }^{286} \mathrm{~A}$ similar course of action was recommended by Bartholomeus Groicki in the mid-sixteenth century. In Titles of Magdeburg Law, published in 1567 , he stated that the form of the will was unimportant, as long as nothing in it was "in violation of the law, statutes (Willkür) ${ }^{287}$ or the rules of propriety." 288 He continued, however, to include sample forms written in Polish of wills made openly before the city office, as well as of closed ones submitted to city authorities for authentication after the testator's death. ${ }^{289} \mathrm{He}$ also included a form written in Latin for entering a closed will into city books. ${ }^{290}$ Containing only the most basic information, the text was devoid of invocations and religious preambles. This reflected a desire to avoid disputes between heirs and facilitate official confirmation of the will's conformity with the laws of the city and their privileges. ${ }^{291}$

286 "Wissit liben herren das ich Kunil Glóke bekenne das ich gemorgingobt habe meyne elichym weybe Cloren L marg und dorczu geb ich yr X marg das ys wem LX marg noch meyme tode in meyne guter ab do icht oberigis bleibit_er do czu recht worde habin dem folgis ys sy den das_s got eyn frocht bescherte. Ipsa prius consensit. Reservat dominium," SCAB. 3, fol. 14ob; cf. "Kunil Geluke cedulam papiream, in quo testamentum suum ac ultimam ipsius voluntatem ydeomate teutonico conscripserat presentavit, cuius cedule tenor sequitur in hec verba: Ich Kunel Glucke bekenne, das ich gemorgengabt habe meyme elichen weibe Cloren L marg. vnd dorczu geb ich ir X marg, das is wern LX marg noch meyme tode in meyne guter, ab do icht oberigis bleybit, wer dorczu recht wurde haben dem folge is, ys sey denne, das vns got eyne frucht bescherte; in quam donacionem ipsa domina presencialiter constituta consensit; reservat sibi dominium, quamdiu vitam duxerit in humanis"; sCAB., no. 1931 (1394); cf. Agnieszka Bartoszewicz, Języki wernakularne

287 See Glossary: Willkur

288 "Every person can make their own testament according to their own wishes, both one made publicly before an authority and a private one, presented to authorities only so it does not go against the law, municipal statutes and good practices. After all, a testament made before an office is a kind of model which may provide a model for other testaments"; Bartłomiej Groicki, Tytuty, 19o.

289 "This summa may be a closed will"; Ibid., 191.

290 "This will be the formulation of a closed will recorded by a notary, if such will is submitted to an office"; Ibid., 193-194.

291 "Coram hoc iudicio personaliter comparens famatus N. sanus mente et corpore, cupiens removere omnes controversias et dissensione, si quae post decessum suum ex hac vita inter suos haeredes de bonis per eum relinquendis quavis ratione oboriri possintm, exhibuit eidem iudicio testamentum suum clausum sigilloque suo obsignatum, volens, ut iuxta illius tenorem de rebus suis disponeretur, atque postulans illud vigore privilegiorum civitati huic concessorum aut iuris ordine confirmari. Quod quidem confirmatum est hac lege, si et in quantum nihil intro contineatur, quod Iuri Maydeburgensi et plebiscitis civitatis huius repugnaret. Dans et concedens haeredibus suis omnibus et in aliquorum absentia praesentibus aut his et his executoribus vel tutoribus N.N. plenam et sufficientem potestatem ac authoritatem, ut post decessum suum ex hac vita ad eorundem instantiam et petitionem testamentum hoc possit aperiri, publice legi, actisque iudiciariis inscribi 
The form from 1485 represents a type of closed will written down as a separate document which was popular in Krakow from at least the late fourteenth century. The will was first written down by hand (often by a professional notary) and confirmed with a stamped seal, and then submitted to the municipal council or bench court, which held it for safekeeping. The document was opened only after the testator's death, when its beneficiaries learned about the provisions it contained and the natural heirs were required to confirm them in the presence of the municipal authorities. Then, to better safeguard the will, its text was entered in an abbreviated form into the municipal book. The formula used in it was very important because it also indicated the testators' right to have all of their possessions, whether movable or immovable, remain at their disposal. The absence of a reference to a division between hereditary and acquired property suggests that this formula allowed for the disposal of both categories of property. The heirs were left only with the requirement to confirm the will's provisions before the court. The principles for bequests of property made in this form were therefore similar to those expressed in the Krakow municipal statute of $1530 .{ }^{292}$ Another important issue was the right to authenticate wills before both the municipal council office and bench court, which also brings this form closer to Krakow's testamentary practices.

A significant number of the wills of Krakovian burghers analysed in this study were found on the pages of the oldest surviving book of wills, established by the municipal council in 1450. This date is indicated by an inscription found on the first page: "Here begins the Book of Wills established by order of the councilors." 293 It should be noted, however, that of the 22 acts of last will from 1427-1449 recorded on the book's first thirteen pages, some have been entered in non-chronological order. Another eleven pages of the book have been left blank, and it is only on page 26 that wills begin to be listed in chronological order, starting with the entries from 1451 . This order is disrupted only by the will of the tanner John Milde, written on page 25 and made in $145^{2}$ before the

absque quarumvis personarum contradictione et impedimento. Dominium tamen sibi opse testator ac plenam facultatem reservavit in his omnibus, quo advixerit, testamentum hoc suum a iudicio rursus accipiendi, mutandi, cassandi in toto vel in parte, aliudque condendi, quandocunque voluerit"; Ibid., 193-194.

292 Cf. Section 4.

293 For unknown reasons, the remainder of this entry was blurred; LT, fol. 1. 
municipal bench court in front of Szewska Gate, which was entered into the book "by order of the councillors selected by him as executors."294 On this basis, it can be concluded that although the book was established in 1450, the municipal councillors and the municipal notary did not begin using it until the following year.

The book was kept until 1623 . Up to the end of 1500 , as many as 188 different bequests of last will were recorded on its pages. It is worth mentioning here the probable reason for the establishment of a new book of wills. The year 1450 was exceptional because it had been declared a Jubilee year by Pope Martin $\mathrm{V}$ in his bull Immens et Innumerabilia, which resulted in a wave of pilgrimages to Rome. The 'eternal city,' with its relics and indulgences, attracted thousands of pilgrims from all over Europe. ${ }^{295}$ Numerous traces of preparations for the journey to the tombs of St. Peter and Paul can also be found in sources from Krakow. In 1450, a record number of twenty five wills and other 'in the event of death' bequests were recorded in the books of the municipal bench court and council. ${ }^{296}$ The pilgrimages to Rome made during the Jubilee year, and the hopes and fears associated with them, generated in people a need to address their earthly and spiritual obligations. This clear interest in testamentary bequests, especially among the city's social elites, was probably the primary factor in the city authorities' establishment of a new book of wills (after the previous Liber Testamentorum in Krakow had been filled up or lost). ${ }^{297}$

The form of the entries in the book of wills in the fifteenth century does not differ fundamentally from the previously discussed acts entered into bench court or city council registers. These included both extensive acts of

294 "Testamentum Johannis Milde cerdonis conditum coram Bannito Judicio ante valvam sutorum et ex mandato dominorum Consulum hic notatum est quia ipsi per dictum Milde electi sunt in tutores presentis testamenti." Below the will there is also a note concerning its execution: "Item anno domini MCCCCLIIII Domus predicta consilio et voluntate dominorum Consulum vendita et resignata es tut in libro Scabinorum, Mathie Brotke"; LT, fol. 25 .

295 For Wrocław: "Sources indicate that jubilee pilgrimages started to gain popularity by the mid-fifteenth century at the latest - the largest number of entries mentioning the Romwege in municipal records (six each) were made in $145^{\circ}$ and 1475"; Halina Manikowska, Jerozolima-Rzym-Compostela, 7-8, 247-253.

296 In the Liber Testamentorum itself there are no entries from 1450; they only begin the following year; LT, fol. 26 .

297 The fact that there was a discontinuity in the keeping of the first and second registers of wills is indicated indirectly by the rapid increase in the number of surviving acts of last will since the 1430s; see chapter 1, section 11, p. 104. 
last will, for example the last will of John Sweidniczer from $1457,{ }^{298}$ as well as short donations, ${ }^{299}$ statements on the appointment of guardians for a wife and children or the executors of the last will, ${ }^{300}$ and mutual bequests. ${ }^{301}$ The wills recorded in these books were made in person by healthy people standing before the municipal council, ${ }^{302}$ or by the infirm in the presence of councillors

298 "Wir Ratmanne der Stat Cracow Bekannen offintlich mit destin brise, Wy das dy Ersamen hern als Walcherus keznig of dy czeit Burgermeister Johannes Pitczen Jacobus Weger Jarosch Scharley und Martinus Belze unsirs Ratis mitbrudere In unsirs Ratis befelunge und in craft unsir hantfesten gegangen woren czu dem Ersamen hern Johanni Sweidniczer unsirs Ratis mitbruder der in crangheit lag czu vorhoren und czu vorstere seynen leczten willen und schikunge seynes testaments und sy noch solcher vorhochunge und unsir befelunge, Wedirkomende in sitczenden Rat bekannende, Wy das der obgenante her Johannes Sweidniczer, Wy wol her crang gewest were Idach mit wolbedochtem mutte, und bey ganczer guttir vormmist seynen leczten willen und testament eigintlich in solchen worten als hernoch folgit gemacht geordint, und beslossen hette"; LT, fol. 39-45 (1457).

299 "Anno etc. XXXII feria secunda diei sancti Mathie apostoli Scharf peter Institor pauper fecit testamentum coram dominis Consulibus Cuncze korsner et Johanne Crancz. Anne uxori sue legavit omnia bona sua que habet post mortem suam habenda cum plena faciendi et dimittendi potestate Exclusis omnes suos consangwineos propinquos et amicas. Sin autem ipse supervivent moriente uxore extunc ipse mulieris quam sua habere cum plena potestate ut super exclusis eciam omnibus propinquis et amicis eiusdem uxoris. Et in hanc ordinacionem testamenti Anna prefata praesentialiter constituta plenarie consensit suscipiens eam pro grato Neutraparcium reservavit dominorum"; LT, fol. 3 (1432).

300 "Anno etc. XXXVI ipso die Invencionis sancte crucis Mathias Engil nomine uxoris sue elegit Tutores petrum bogner, Johannem Phert et Johannem Litwanum aurifabros Cives Cracovie, Quos supradictos dictus Mathias ut dictam suam uxorem Margaretam et filios eius tuerentur et providentur eisdem sicut veri et legittimi Tutores In omnibus causis et negocys ipsorum Excludens omnis et singulos consangwineos et propinquos tam suos quam uxoris sue quantis Iuris est voluitque in casu si aliquis aut aliqui dictorum Tutorum decederent, quod superstites meliori kosilio et concorditer alium seu alios loco ipsius seu ipsorum eligerent sit quod dictum numerus integer remaneret. Et hot fecit de consensu uxoris sue tunc presentis petuitquedominos Consules Quod predictam electionem Tutorum ratam haberent et confirmarent. Ad predicta stans uxor sua ad omnia singula immunit et consensit presentibus dominis Petro Graser et Wilhelmo Wylanth"; LT, fol. 3 (1436).

301 "Feria VI ante Viti Anno 1482. Nicolaus Graudencz frisz und gesunt mit seynen gutten willen stehende vor uns hot alle seyne gutter bewegliche und unbeweglich dy her itczunt hot und her nochmols haben wirt Anne seynir hawsfrawen noch seynen tode zu haben ofgegeben und vorreichit und her wedir Anna obgenanten hot alle guttir beweglich und unbeweglich dy sy itczunt hot und her nochmols haben worde Nicolao Graudencz yren elichen manne noch yren tode zu haben ofgegeben und abegetreten awsslisende alle yre nesten frunde und mogen an beyden teylen Behaldende yn dy herschaft dy weyle sy leben dys zu wandeln und weddirczuruffen wen sy wellen"; LT, fol. 129 (1482).

302 "Anno domini Millesimo CCCCLVI feria quinta post Vitalis Hannos Lode Coram Consulam fecit suum Testamentum in hunc modum. Hannos Lode unsir mitburger wellende 
who came to their house. ${ }^{303}$ Many wills were 'closed,' in other words, they had been previously written in person (in a few cases) or by a notary, 304 and afterwards authenticated by the testator or the executors of the will. It seems that the desire to record one's will in the Liber Testamentorum was associated with the special prestige of this book and the accompanying sense of better safeguarding the act of last will by placing it under the authority of the municipal council. This confidence continued up to the end of the fifteenth century, when the number of wills entered into council books (including the Liber Testamentorum itself) decreased, while the number of bequests made and secured by aldermen increased.

In 1476 Stephen Eichorn and his wife Margaret made an act (in German gemechte) comprising both a will and a mutual donation. In this act, they provided for the mutual inheritance of a house on Wiślna Street. After their deaths this house and other movables were to be divided into three parts and passed on to their designated relatives. In addition, both bequeathed 100 florins for the payment of annual rent for a German 'preacher' in St. Mary's Church. ${ }^{305}$ Later, in 1482, it was added to the council book in a different hand that Stephen Eichorn had revoked this entry in order to have it included in the book of wills. ${ }^{306}$ In fact, in that same year, a bequest appeared in the Liber Testamentorum, in which he revoked all his previous wills, stripped his previously chosen guardians of power and announced his intent to choose new ones, making his

czyen wedir dy ungetrawen finde der Cristenlichen glawbins dy Turken vor sitczendem Rate machende seyn testament frisch und gesint bey guttir vornumft in solchen worten. Czum irsten gebe ich Margarethe meyner Hawsfrawen hundirt ungerische gulden noch meynem tode czu haben. Item meynem bruder Niclos Loden czu Pilsen czeen gulden dy sal sy haben wenne sy mondig wirt. Item in das Spital czu Cracow czeen gulden, und behalde mir desis testamentes hirschaft czu wandiln dy weyle ich lebe, und kyse czu awsrichtunge des Matis Paschken, Hannos Frankensteyn, und Niclas Menteler"; LT, fol. 37 (1456).

303 "Anno domini Millesimo quadringentesimo LX quinto sabato ante Invocavit Dominus Johannes Beme in stuba domus sue habitationis consedensque cum dominis Infrascriptis ad eum missis licet corpore debili usu tamen bone et perfecte racionis suum fecit testamentum in fornace cum dominis sedens videlicet domino Johanne Wirsznik, magistro Curium, Paulo Newburger, Johanne Mozancz et Johanne Teschner, tale condidit et sue ultime voluntatis disposicionem seu testamentum prout sequitur"; LT, fol. 86 (1465).

304 E.g. the will of Peter Schepcz; LT, fol. 137 (1483).

305 "Stephan Eichorn und Margaretha seine hausfrawe unsir mitteburgir, haben eyn sulche gemechte macht von allen iren guttirn beweglich und unbeweglich keyne awsgenomen, und iren testament und schickunge ires letczen willen gesunt und bey guttir vornunft wesinde, also das"; cons. 429, fol. 557.

306 "Anno 1482 Steffan Eichorn revocavit hot totam volens ut esse utqui in libro testamentorum"; CONS. 429, fol. $55^{8}$. 
will before the municipal bench court. ${ }^{307}$ In this case, it is not clear why the testator revoked his previous wills and, ultimately, despite his announcement, chose not to make a new act in the book of wills, though the expression of such a need is characteristic in itself. ${ }^{308}$ In the case of a will personally written by Peter Schepcz, his executors decided that, in addition to entering it into the book of the municipal bench court, the act of last will should also be confirmed by an entry in the book of wills. ${ }^{309}$ Entering the text of a will into more than one official book gave the impression that it was better safeguarded.

The same situation occurred seventy years earlier, in 1413, when Nicholas Czeginkop's will was entered into the book of the municipal bench court. His last will was first written on a sheet of paper in the presence of two councillors who came to him while he was sick, after which, at the order of the municipal council, it was written on parchment in the form of a document. In the end, the executors of the will "for its better protection" brought it before the municipal bench court, while the aldermen entered it into their book, where it survived to the present day. A similar need to authenticate an act of last will by aldermen can be found in a will from 1408. John the Wheelwright (stelmecher), who bequeathed all his property to his wife and daughter before the municipal council, asked his legal representative to confirm this act before the vogt and aldermen. ${ }^{310}$

The bench court's jurisdiction over wills became so strong over time, that in wills from the 148 os and 149 os city privileges are invoked that seem to justify wills being made in the presence of visiting councillors. For example, in the

307 "Steffan Eichorn stehende vor uns hat weddirruffen alle testament dy her gemacht hette bis of den hewtigen tag wellinde dy machtlosz seyn benemende seyn vormunde dy macht dy her vormols gekoren hat und her wirt andir kysen und testament machen vor gehegtindinge"; LT, fol. 133 .

308 Due to a lack of books of the nunicipal bench court from 1476 to 500 it is not known whether Stephen Eichorn kept his promise.

309 "Herren Ulricus Jeczinbergir und Stanislaus Lanthman gekorne vormunde Petri Schepcz Testament dem got gnade legeten vor uns vedir des selben Petri Schepcz Testament welche her bey gesunde leibe und seynir eygen hant geschriben hat und vorsigilt in unsir gerichte den Scheppen ingelegit hat In sulcher weyse, worde got obir yn etwas todis halbe thuen das is bunt und craft sulle haben sam is in der Scheppen buch wen geschreben noch ynnehaldunge unsir Scheppen bucher begereten von uns das is solte werden gelesen und dorch uns mit unsirm buche och worde bestetigit welchis gelesen wart in keginwortikeit der obgenanten czwir vormunde und Petri des obgenanten Petri Schepcz Eldistir zon und lawtet von worte zu worte"; LT, fol. 137 (1483).

310 "[...] reservans sibi dominium quamdiu vixerit et constitutus Hartlibum de Clucze in procuratorium ad predictum resignacionem in bannito proximo iudicio coram advocato Scabinis confirmandam"; cons. 427, fol. 328 (1408). 
bequest of last will of Wojtek the Armourer (plathner) from 1487, the document is described as having been made "by virtue of privileges, etc., according to the custom of the office,"311 and that of Barbara, daughter of Michael Unger, from 1491, "by virtue of the city's privileges" (vigore privilegiorum Civitatis). ${ }^{312}$ For some reason, after almost a century of writing wills in the presence of representatives of the municipal council, the need arose once again to emphasise the rule of law, citing privileges and city customs. Although we may only be dealing with the style of a single municipal notary, ${ }^{313}$ these phenomena generally indicate that a process of change was underway in terms of who was authorised to draw up and certify wills, a competence which had rested with the municipal council since the late fourteenth century, and with the municipal bench court in the late fifteenth century.

\section{1 \\ The Number of Wills in Krakow from 1300 to 1500}

Graph 1 illustrates the increasing popularity of the will as an institution and changes in the burgher class' perception of it in the fourteenth and fifteenth centuries. The lines indicate both the number of preserved wills in total and the number found in particular types of sources, including books of the municipal bench court, council books, the Liber Testamentorum and other sources. The shape of this graph was largely influenced by the state of preservation of these sources. The books of the municipal bench court from the years 1376 to 1390 are

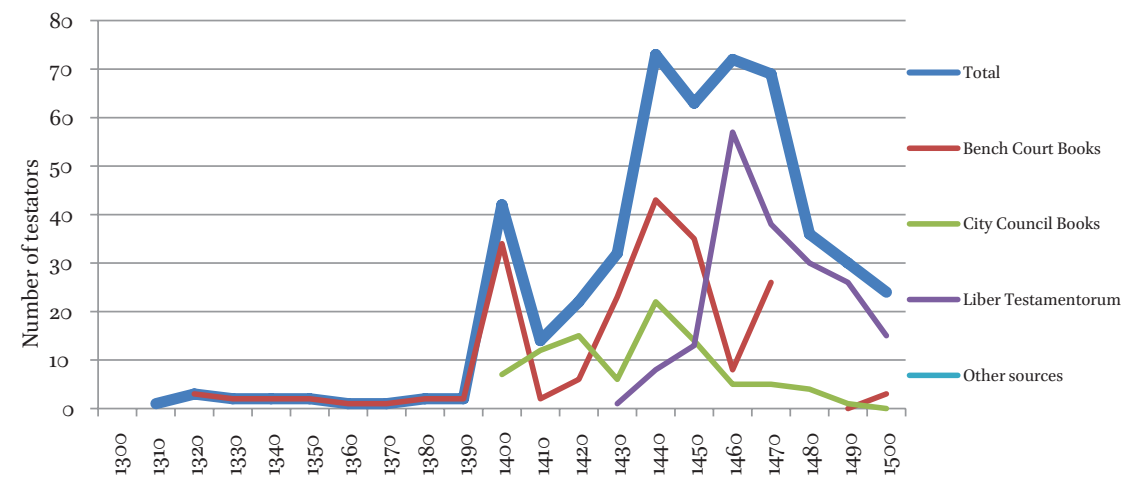

GRAPH 1 Number of extant wills from various sources from 1300 to 1550, by decade

\footnotetext{
$311 \quad$ LT, fol. 143.

$312 \quad$ LT, fol. 149.

313 The municipal notary John Heydeke worked in the municipal office during the period from 1481 to 1500 ; Bożena Wyrozumska, Kancelaria, 125-126.
} 
missing, so it is unclear whether the sudden increase in the number of wills in the 139 os was preceded by increases in previous decades. Similarly, the absence of the books of the municipal bench court from the turn of the fourteenth and early fifteenth centuries and from the last 24 years of the fifteenth century significantly blurs the image obtained from this data. Yet, even bearing these limitations in mind, two very important phenomena can still be identified. First, the significantly lower number of wills from the years 1400 to 1430 coincides roughly with a period covered in the first book of wills, which has been lost. The reason for this apparent interval of approximately 20 years between the first and second book of wills cannot be determined today with certainty, but it can be assumed that this gap is related to the exclusive nature of this book. It seems that the first, lost Liber Testamentotum et Dotaliciorum was even more elite in character than the second, surviving book of wills. After either its completion or destruction, only a few bequests of last will were entered each year into the books of the council and municipal bench court (this can be seen in the diagram below), which were maintained parallel to one another. This situation changed during the Jubilee year in Rome in 1450, and the growing number of burghers who sought to authenticate their act of last will before leaving on a pilgrimage to the 'holy city.' The second phenomenon is related to the surviving Liber Testamentorum. On the one hand, after its introduction in 1450, the number of wills entered in council books in Krakow declined significantly, which shows that the municipal council consistently held to the practice of entering such acts in the Liber Testamentorum. On the other hand, there are interesting correlations between the book of wills and the wills recorded in the books of the municipal bench court. The number of wills in the latter dramatically decreased with the establishment and maintenance of the Liber Testamentorum from $145^{\circ}$ to 1460 , but started to increase again from 1460 to 1476, a time when the number of entries in the Liber Testamentorum was declining. The absence of the books of the municipal bench court from the years 1476 to 1500 does not allow for unequivocal confirmation of this tendency, but there is good reason to believe it: this includes the rapidly decreasing number of wills in the Liber Testamentorum in the last quarter of the fifteenth century, the lack of wills written in council books, and the large number of wills found in books of the municipal bench court in the years 1500 to 1550.314

314 From the beginning of the sixteenth century, the number of surviving wills definitely increases. The number of wills recorded on the pages of bench court book from 1500-1513 is considerably higher than in the precedeeing years, both in council and bench court books. For example, among the 16 wills for the year 1501, 13 are recorded in the bench court book. Similarly, in the year 1502, from a total of 15 surviving wills, 13 are found on the pages of the bench court book, and the other two in the 'Liber Testamentorum.' The 
This graph also confirms that the municipal bench court had been gradually assuming authority over wills since the 1470s. The reasons for this shift are not entirely clear; however, as already suggested, it is possible to point out a few phenomena that might be relevant in this respect. One of these was a developing sophistication in municipal legal system and growing knowledge of its fundamentals among the urban elites, which led to a more careful delineation of the functions and responsibilities of different municipal authorities. ${ }^{315}$ This is indirectly proven by judgements relating to wills issued by the Higher Court of Magdeburg Law at the Castle of Krakow. Because the city of Krakow had its own privileges and local customs, the judgments of the court were usually addressed to other towns and villages in the 'Lesser Poland' region (Matopolska). ${ }^{316}$ They often emphasized the legal principle derived from Magdeburg Law of the legality of wills being authenticated before a municipal bench court. ${ }^{317} \mathrm{~A}$ better knowledge of Magdeburg Law (extended to include verdicts $[\text { ortyle }]^{318}$ and attached Romanistic Glosses, i.e. legal opinions [glossy]), even if this was limited to the local authorities and municipal notaries, could have translated into a growing tendency to certify wills before this municipal organ.

Yet, the role of other factors cannot be overlooked. The municipal council, which, at the turn of the fourteenth and fifteenth centuries, sought to assume authority over wills (drawn up in the vast majority of cases by members of the urban elite) for reasons of prestige, and in order to oversee the religious activities of city inhabitants, may have lost interest in them and their broad dissemination, particularly given that, during a time of plague, the Krakow custom of representatives visiting the sick was simply dangerous for health and life. In the second half of fifteenth century, as the fear of plague increased, so did

total number of surviving wills from 1300-1550 was calculated by myself in Katalog testamentów z krakowskich ksiag miejskich do 1550 roku (Warsaw: Semper, 2017).

315 Urszula Sowina has noted that "in medieval and early modern Krakow, testamentary dispositions were registered primarily in the books of the municipal bench court - the body responsible for private law, including provisions and decisions concerning the means for transferring property"; eadem, Testamenty mieszczan krakowskich o przekazywaniu majactku, 175 .

316 Among the 61 cases concerning wills from 1456 to 1511 in which the Higher Court of Magdeburg Law at the Krakow Castle ruled, just one, dating from 1502 and referring to a Krakow townsman is indirectly connected with a will; Decreta iuris supremi Magdeburgensis castri Cracoviensis. Rechtssprüche des Oberhofs des deutschen Rechts auf der Burg zu Krakau, vol. 2: 1481-1511, eds. Ludwik Łysiak (Frankfurt am Main: V. Klostermann, 1997), no. 881 .

317 Michał Wiszniewski, Historya, 228-229.

318 See Glossary: Urteil 


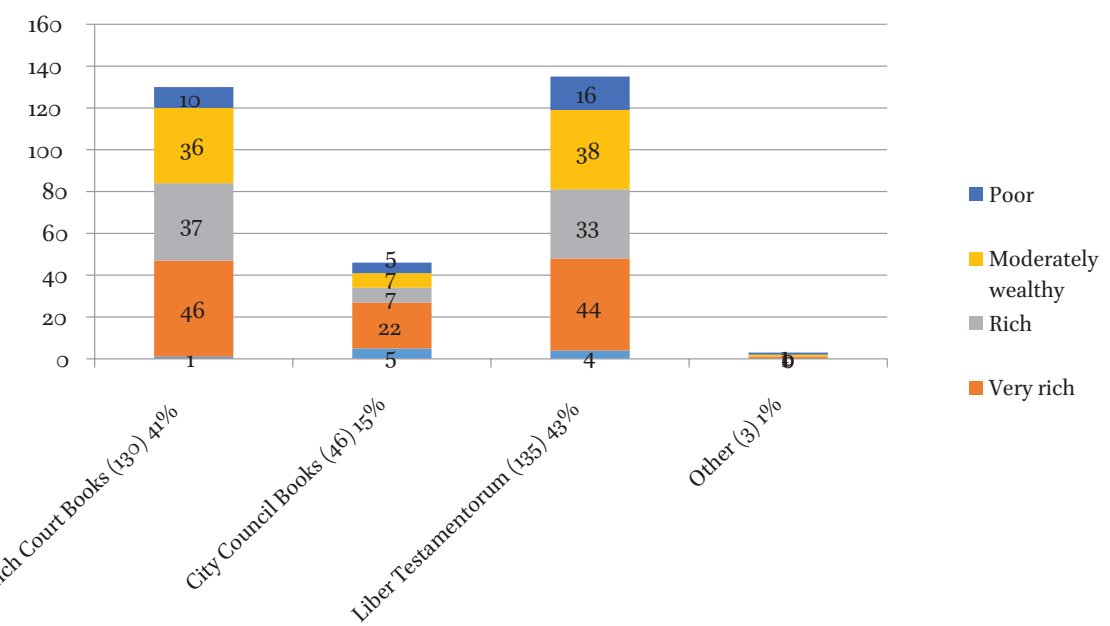

GRAPH 2 Number of wills per type of book from 1427 to 1476, taking into account the assets of testators. ${ }^{320}$

the reluctance to fulfil this onerous duty. ${ }^{319}$ It is unsurprising that it was only in the latter half of the fifteenth century that it was underscored in the text of a will that it had been written during a time of plague (temporis pestilentia). The plague afflicted the inhabitants of the city several times during the period under consideration, the most tragic of which seems to have been the plagues of 1466 and 1482, i.e. during the changes concerning the control over wills discussed above.

From 1427 to 1476 , i.e. from the first will entered in the extant first book of Liber Testamentorum, to the last date of the final entry in the last extant fifteenth-century book of the municipal bench court, 322 acts of last will have survived. In Graph 2 above, which shows the number of wills preserved in particular types of books, we can see an interesting phenomenon: there is a certain balance in both the number (140 to 133 records of last will) and the social position of the people whose wills were included in the books of the municipal bench court and in the book of wills. However, if we take into account both the entries in council books and in the Liber Testamentorum itself, we can notice

319 Urban elites tended to leave the city to escape epidemics; Andrzej Karpiński, $W$ walce z niewidzialnym wrogiem. Epidemie chorób zakaźnych w Rzeczypospolitej w XVI-XVIII wieku i ich następstwa demograficzne, spoteczno-ekonomiczne i polityczne (Warszawa: Neriton, 2000), 82.

320 The division based on the economic status of the townspeople applied here is discussed in more detail in Chapter 2, Sections $5^{-9}$ on the economic stratification of Krakow testators. 


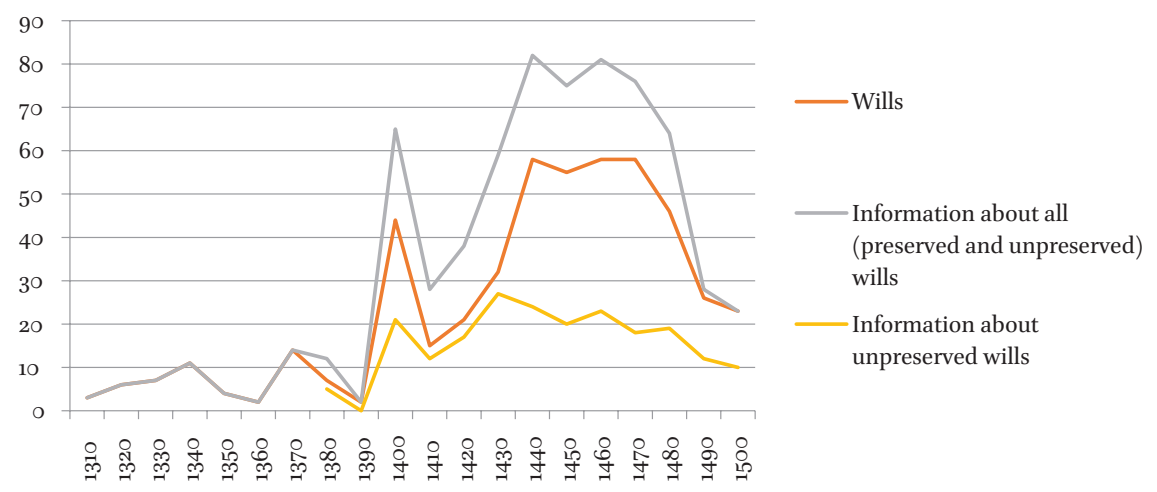

GRAPH 3 Number of testators whose wills have survived to the present day and of those whose wills are only mentioned in the source material.

that in the five decades covered, the municipal office maintained a numerical advantage over the bench court in terms of registering and authenticating Krakovian burghers' bequests of last will. As we can see in Graph 1, this situation began to change only in the latter half of the 146os.

Another key issue significantly affecting the perception of the will as a social and cultural phenomenon in the lives of Krakow's burghers is the question of its prevalence in Krakovian society and the representativeness of the surviving wills in relation to all the wills written down in this city during the analysed period. In order to answer these questions properly, all references to the burgher wills were collected from municipal books, including both those relating to surviving wills and those referring to wills that have been lost. The results of this research were quite surprising, as can be seen Graph 3 .

The graph shows three types of collected information: that relating to all testators in Krakow, to those whose wills have survived to the present day, and to those whose bequests of last will have been lost. In the years 1390-1435, the lines indicating the number of wills surviving and lost reflect similar trends indicating a rapid growth, then decline and finally a gradual increase in the number of wills made by Krakovian burghers. This data confirms observations mentioned earlier about the state of preservation of the sources. In the 1430s, the two lines rapidly diverge from each other, indicating a significant change in the ratio of extant wills to lost wills, in favour of the former. This graph therefore also confirms the 1430 s as the probable end of the functioning of the first, lost book of wills. Only the absence of books of the municipal bench court from the last quarter of the fifteenth century and the declining number of wills entered onto the pages of council books during that period leads the two lines to once again converge.

These studies also allow us to draw certain conclusions concerning the popularity of the will as an institution in late medieval Krakow. Even taking 
into account the aforementioned incomplete preservation of sources in the city and the lack of reference to those wills which did not require confirmation before the municipal court because they did not involve the disposal of real estate (apart from that which fell under the traditional rules of inheritance), it must be assumed that the number of all wills written down in Krakow was not large. In the period during which the books of both the city council and the bench court have been best preserved, i.e. 1440 to 1476 , the number of references to wills that have been lost represents only half of the number of surviving wills. Even if one takes into account the factors mentioned above, which lead to an underestimation of the number of wills that have been lost, the number would still not be much higher. These observations make it possible to assert that the will as a phenomenon was to a large degree elite in nature and extremely limited in its prevalence, being of interest primarily to individuals from the richest burgher families in Krakow. The will in late medieval Krakow should therefore be treated as a manifestation of 'high culture' in a medieval city, rather than as an element typical of the community as a whole. Despite the growing number of people who became interested in the will as a means of settlement of accounts at the end of their life, it did not lose its elite character during the period under examination. This act remained strongly associated both with participation in writing culture, which was still an elite sphere in the late medieval city, and with the culture of written law and its increasing codification. ${ }^{321}$ Agnieszka Bartoszewicz, who has conducted studies on the writing culture of small and medium towns in late medieval Poland, argues that the spread of the practice of making wills influenced the development of pragmatic literacy among burghers. ${ }^{322}$

Wills, commonly referred to as 'testaments', which are extended dispositions in the event of death, are the principally analysed sources in this book. However, fourteenth- and fifteenth-century municipal books include records of many other individual bequests which served a similar function and were written for similar reasons. For example, there are various bequests made 'between the living' (inter vivos) i.e. taking place during the one's life that, nevertheless, could serve a role similar to 'gifts because of death' (donationes mortis causa). They consisted of single pious bequests for opera pietatis (95 of them) and post mortem bequests for selected family members (356). Mutual bequests ( 385 ) also played an important role, often replacing written wills, but also sometimes complementing them. Much less numerous were the separate provisions for

\footnotetext{
321 As opposed to traditional customary law, which was to a greater extent a part of popular culture; cf. Leopold Pospísil, Anthropology of Law. A Comparative Theory (New Haven: Harper \& Row, 1974), passim.

Agnieszka Bartoszewicz, Piśmienność, 255.
} 
wives, aimed at securing the position of the widow after the death of her husband (79). The fact that information on the provisions of dowers in marriage contracts has been preserved much more often in testaments than in the form of separate entries in city books, and that testators often decided to increase their value significantly in their bequests of last will, clearly indicates the affinities between these two types of acts. ${ }^{323}$ There was not always a sharp line between wills and acts appointing guardians (tutores) for property, wives and children during the absence and after the death of the husband. For example, during the plague in 1467 , councillor John Gartner made a bequest before the municipal bench court in which he chose as guardians for his wife Barbara and children, councillor Martin Chmiel and future alderman John Kunisz the Furrier (to whom he left the right to choose another guardian in the event of the death of one of the two listed), and also testified that he owed 100 grivna to his wife. ${ }^{324}$ Just as wills of this kind were occasionally inscribed in the Liber Testamentorum, they were also made in the same circumstances: during epidemics of plague, ${ }^{325}$ and before a long journey or war. ${ }^{326}$ The situation was similar for testimonies made by burghers concerning the handling of debts and liabilities in the event of their death. Some of these types of testimonies entered into council books were not treated as wills, while wills that essentially contain only information on debts and liabilities have survived. This is the case, for example, with the bequest in the council book of 1439. The mayor, along with the two councillors sent in the name of the municipal council, went to the house of councillor John Slepkogil, who in their presence testified to debts amounting to 575 grivna. He outlined how they were to be paid, and declared that his wife Agnes did not possess any of his property, and that he had no rights to her silver or any other movable property, thus protecting her from liability for his financial obligations. ${ }^{327}$

All this gives the impression of great chaos, and of inconsistencies and a lack of a means for formally defining the character of such acts and what

\footnotetext{
323 Cf. Section 6, p. 70.

324 SCAB. 8, fol. 269 .

325 E.g. the disposition of Anna Gliwiczowa from 1465, CoNs. 429, fol. 365; of John Gartner from 1467, SСАв. 8, fol. 269 or of Wilhelm Megirszheimer of Dinkelsbühl (von Thunkilspul) from 1482, LT, fol. 135-136.

326 E.g. Adam Czech 'ad expedicionem transiens' in 1410, CoNs. 427, fol. 376; John Stochse the gunsmith 'iturus ad expedicionem contra prutenos' in 1433, coNs. 428, fol. 317; Stanisław the cartwright 'volens proficisci contra Thurcos' in 1464, LT, fol. 81. CONs. 428 , fol. 397 .
} 


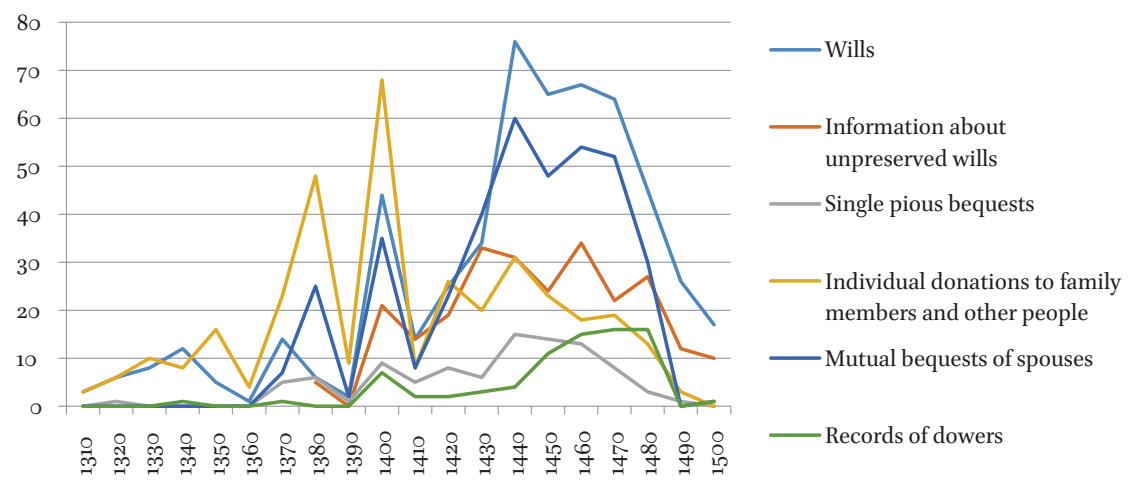

GRAPH 4 Wills and other types of donations and dispositions

distinguished them from one another. ${ }^{328}$ Although the present book primarily analyses bequests that are more extensive in nature, during searches of source materials other, shorter bequests were also collected. The chart below outlines the different types of acts mentioned above, together with the number of wills and references in sources to lost wills in various decades of the fourteenth and fifteenth centuries. What can be seen here, above all, is that most of these (mainly donations to family members and mutual bequests) reflect the same upward and downward trends that are also observed in wills. This reflects to a certain extent the state of preservation of the source materials (especially books of the municipal bench court), but it also seems to reflect similarities in the nature of these bequests. It is also interesting to note that individual donations to family members declined significantly as wills proliferated during the fifteenth century.

In total, during the two-hundred-year period analysed, more than two thousand different kinds of bequests of a dispositive nature related to death and preparations made for it were registered (in this context, one can also include bequests of marriage dowers drawn up after marriage; see Graph 4). This number, although it is still not comparable with the number of preserved records of last will from large urban centres in Western Europe, stands out significantly when compared to the number of wills from cities in the Central European region. ${ }^{329}$

328 "When examining mortis causa dispositions made on the basis of municipal law, one has to take into account limitations caused by the lack of precise terminology that would have made it possible to distinguish them from alienation through acts made between the living."; Krystyna Bukowska, Orzecznictwo, 93.

329 Paul Baur, Testament und Bürgerschaft, 30; Martin Nodl, "Středověký testament jako abnormalita," in Pozdně středověké testamenty v českých městech. Prameny, metodologie 
A cursory review of surviving last wills shows the influence of epidemics and other external factors on the number of wills recorded; however, more can be seen by analysing the number of wills made in specific decades of the fourteenth and fifteenth centuries. Graph 5 provides a breakdown by year of surviving wills found in different types of municipal book. The chart indicates that in most years during this period no more than five bequests of last will were made. Given Krakow's size, this small number of acts of last will allows us to assume that they were most often made for purely personal reasons. There are only a few years in which the number of wills exceeded ten, which seems to indicate that these rises were motivated by extraordinary circumstances. The most important of these were epidemics of infectious diseases (marked in Graph 5 on the lower axis of the graph with black squares) and years of Jubilee (marked with red squares ), which encouraged numerous pilgrimages from Krakow to Rome. This correlation is most evident in the wills made during the Jubilee year of 1450, the plague epidemic of 1466-1467, the subsequent Jubilee year of 1475, and the plague epidemic of 1482-1483. In the last case, however, the lack of books of the municipal bench court prevents us from properly assessing the scale of this phenomenon (the same is true for the plague epidemic of 1494-1497). Two other years in which an equally large number of wills was recorded - 1439 and 1458 - are noteworthy. In both cases, there is a surge in the number of wills. ${ }^{330}$ Although surviving wills do not reveal the causes of this steep rise, in the first case, it may reflect the impact of major fires that in 1439 engulfed houses on Shoemaker's Street, Szczepańska Street, Jewish Street and St. Nicholas street in the city suburbs. ${ }^{331}$ However, it is worth noting the lack of a similar increase in the number of wills in other periods in the fifteenth century, during which

a formy ryužití. Sbornik př́spěvků z konference usporádané 3o. listopadu 2005 Archivem hlavního města Prahy a Historickým ústavem Akademie věd České republiky, eds. Kateřina Jišová, Eva Doležalová (Praha: Akademie věd České republiky, 2006), 73-85.

330 There are eight surviving wills from 1438, 18 from 1439, and seven from 1441. Similarly, there are eight extant bequests of last will from 1457,15 from 1458, and eight from 1459; see the list of wills in the Annex of the present book.

331 "Urbs Cracoviensis eo anno duplex incendium pertulit: unum feria quarta quatuor temporum Penthecostes, quo tres platee: Sutorum, Sancti Stephani et Iudeorum, aliud vicesima tercia Iulii, quo platea Sancti Nicolai et suburbia eius conflagrunt"; Joannis Dlugossii Annales Seu Cronicae Incliti Regni Poloniae: Lib. 11 et Lib. 12, 1431-1444 (Warszawa: Wydaw. Naukowe PWN, 2001), 206; cf. Jana Dtugosza kanonika krakowskiego Dziejów polskich ksiag dwanaście, vol. 4, trans. Karol Mecherzyński, ed. Alexander Przeździecki (Krakow: Drukarnia W. Kirchmayera, 1869), 574. 


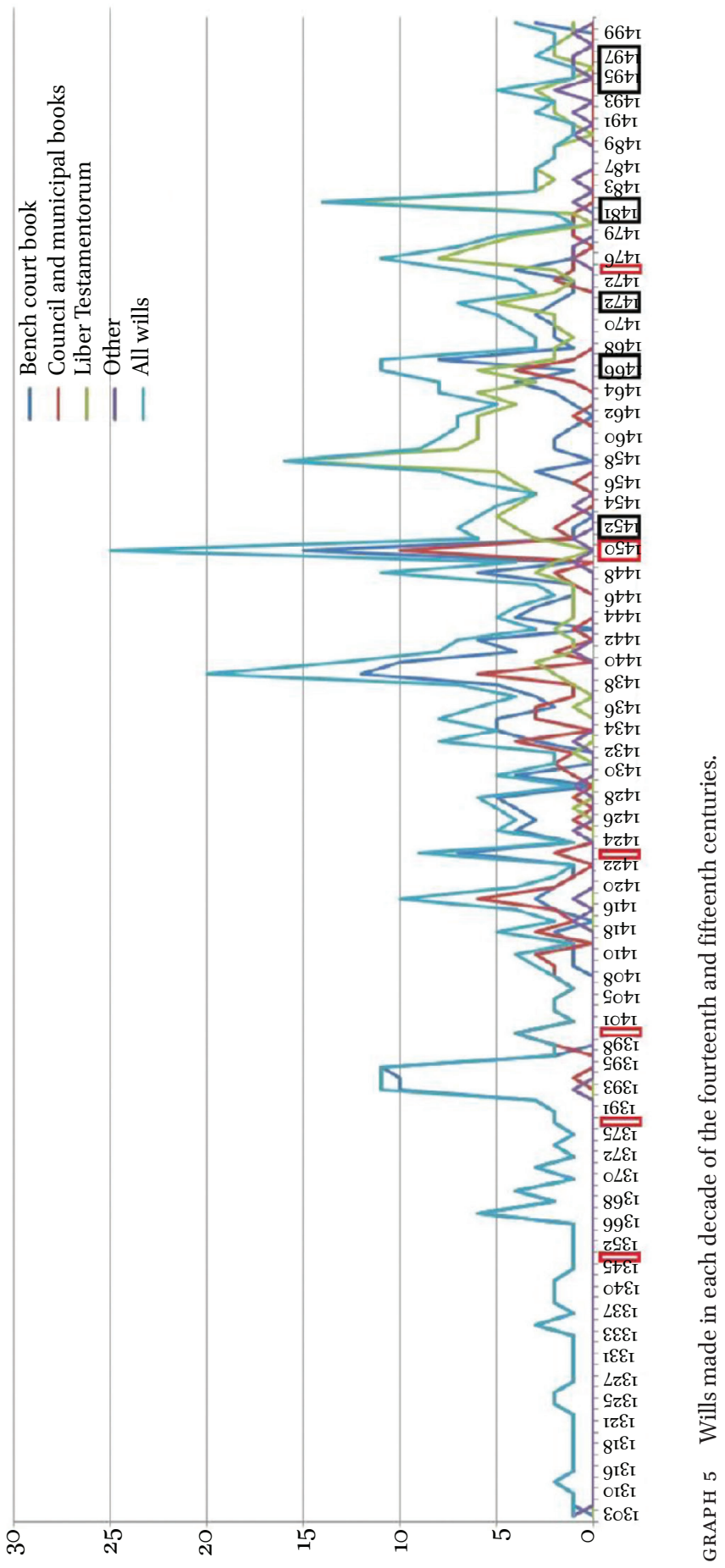


time there were equally severe or more serious natural disasters that struck Krakow. A decrease in the number of wills is recorded in the city both during and after the great earthquake of 1443, and following the fires of 1455 and 1462. There is also no correlation between the number of wills and the great flood that inundated the city in $1475 .{ }^{332}$

The motivations for writing wills, sometimes given by testators in the arenga (preamble) of these acts, are most often spiritual or family-related. In the first case, wills served as a vehicle for making pious bequests intended to ensure the salvation of the donor's soul; this role came from the very concept of the so-called 'canonical will' and from individual bequests for the soul, called seelgerethe in German. For example, in 1440 a professional court plenipotentiary named Lawrence made a will, as he himself wrote, "out of his love of God and for the rescue of his soul" (Ich Lorencz vorreder mache meynament gote czu lobe und meyner zele czu hulfe). ${ }^{333}$ As seen in the arenga of various wills, these acts also provided instructions for the distribution of assets and the principles for the peaceful mutual co-existence of the testator's close relatives, after his death. This is mentioned in the will of councillor George Lange from 1497: "George Lange, our fellow councillor, healthy in body and mind, standing before the council today, made his last will and provided for the division of his wealth, so that after his death there would be no disputes between his wife and children."334 Although such annotations began to appear in testaments only at the end of the fifteenth century, there is no doubt that these same reasons had led people to make such acts much earlier. The majority of wills took both of these aspects into account, as is clearly indicated by the will of councillor Nicholas Zarogowski, who "in order to ensure the salvation of his soul, standing before the council, handed over his will, written on a piece of paper, and his bequests of last will, asking that they be accepted and confirmed by the councillors, so that later there would be no disputes between his sons, daughters and wife." 335 Burghers' reasons for writing down their wills also included making preparations before a long journey military campaign, or pilgrimage,

\footnotetext{
332 Stanisław A. Sroka, "Klęski elementarne w Krakowie," Rocznik Krakowski 67, 2001, 13-18.

333 SCAB. 6, fol. 213 .

334 "Der Ersame herr Georgius Lange unsirs Rathismitbruder frisch und gesunt mit wolbedochtem mute hic ym sitczendem Rathe auschinde hewt dy ferlickeit der czeit hat gemacht seynen leczten willen und schickunge seynir habe of das noch seynen tode czwuschen seynir hawsfrawen und seynir kindern nichtis czwetracht irstunde"; LT, fol. 155-156.

335 "Famosus dominus Nicolaus Zarogowsky confrater noster sanus mente et corpore non coactus nec compulsus sed de bona voluntate volens providere saluti anime sui coram nobis stans Testamentum suum et ultime voluntatis disposicionem in cartis scriptum reposuit petens id a nobis suscipi et actis nostris confirmari ne in post inter filios et filias ac uxorem suam aliqua lis sive discordia fiat"; LT, fol. 128-131 (1482).
} 
all of which were associated with the risk of loss of life. ${ }^{336}$ Here too, family and religious reasons tended to play an equally important role. The aforementioned councillor Nicholas Zarogowski gave an interesting explanation for the writing of his will in 145 o before going on a pilgrimage to Rome. He wrote that he made it "so that his successors would not make mistakes."337

The answer to every question about what guides peoples' actions or decisions lies somewhere within three levels of human consciousness: the conscious, subconscious and unconscious mind. If we want to delve deeper into the motives that guided testators in Krakow, we can assume that the hidden psychological factors involved included efforts to attain prestige in a given social group, and sympathies and antipathies felt towards family members and other people close to them. Factors of which they would not be conscious, or only weakly aware, include the natural fear of death and their psychological defence mechanisms to suppress it, and the desire to ensure they would be remembered in the future. ${ }^{338}$ To these two groups of factors creating a need in people to write down an act of last will, we can also add the internal desire to improve themselves and make redress for actions they felt violated their personal moral codes. A good example of this is a bequest in the will of Gottfrid Fattinante from Genoa, in which the testator clearly states that as a councillor and steward of the municipal treasury, a lack of vigilance in the decisions he made or funds he disbursed could have caused harm to the city, and therefore "in this hour of compensating and repaying debts" (in horum recompensam ac satisfaccionem debitam) he bequeathed to the city of Krakow the significant sum of 600 grivna to be paid to its creditors. ${ }^{339}$

336 E.g. CONs. 429, fol. 676 (1480), 693 (1481); cons. 427, fol. 376 (1410); cons. 428, fol. 317 (1433); LT, fol. 81 (1464); NKiRMK, no. 616 (1321); CoNs. 428, fol. 513 (1448); SCAB. 8, fol. 575 (1475).

337 "Ego Nicolaus Zarogowsky ob anime mee salute proponens limina beatorum Petri et Pauli in hoc Jubilei visitare accidente casu si me interim ab hac luce migrare contingeret primitus testamentum meum coram dominatoribus nostris facio et statuo in hac forma ut successors mei errore non pertirbentur"; cons. 429, fol. 15-16.

338 Otto Gerhard Oexle, "Die Gegenwart der Lebenden und der Toten. Gedanken über Memoria," in Gedächtnis, das Gemeinschaft stiftet, ed. Karl Schmid (München-Zürich: Verl. Schnell \& Steiner, 1985).

"Ceterum quia pretactus Gottfridus quondam distributor peccuniarum Ciuitatis Cracouiensis et legalis Consul extiterat, et si ex sua negligencia in consulendo, distribuendo seu exaccionem exsoluendo aliquos errores commisisset, ex quibus ipsi ciuitati damna aliqua euenissent, ideo in horum recompensam ac satisfaccionem debitam predicte Ciuitati Cracouiensi quingentos florenos aur veri debiti duci Russie mutuatos et concessos, pro quibus Gocze Czeyn predictus et Martinus Varschow fideiusserunt, prout in eorumdem desuper confectis patet uteris, et apud Henricum Schuler centum marcas predicte Cíuitati Cracouiensi perpetuo contulit atque dedit”; KDWac., vol. 2, no. $396,182-185$ (1393). 